\title{
Taxonomic Review of Fossil Coleopterous Families (Insecta, Coleoptera). Suborder Archostemata: Superfamilies Coleopseoidea and Cupedoidea
}

\author{
Alexander G. Kirejtshuk $\mathbb{D}$ \\ Zoological Institute, Russian Academy of Sciences, Universitetskaya emb. 1, 199034 St. Petersburg, Russia; \\ agk@zin.ru or kirejtshuk@gmail.com \\ Received: 6 December 2019; Accepted: 4 February 2020; Published: 17 February 2020

Abstract: The paper is the first of a series, which aims to present a consistent interpretation of the suprageneric taxa of fossil beetles in the current century and their generic and species composition. Order Coleoptera is considered in composition of the superorder Coleopteroidea Handlirsch, 1903 (= Coleopterida sensu Boudreaux, 1979, nec Pearse, 1936) together with orders Skleroptera and Strepsiptera, and also with the family Umenocoleidae of unclear position. This paper includes the archostematan superfamilies Coleopseoidea and Cupedoidea of the infraorder Cupediformia, i.e., Coleopseidae (one genus and one species), Tshekardocoleidae (12 genera, 15 species), Labradorocoleidae (one genus, one species), Permocupedidae (together with Taldycupedinae, stat. nov., 24 genera and 54 species) and Cupedidae (three subfamilies, 49 genera, 253 species). The preliminary information on structure of the larva of Tshekardocoleidae from Tshekarda is done. There are also described the new taxa: genus Afrotaldycupes Kirejtshuk, gen. nov. with the type species: genus Taldycupes africanus Ponomarenko in Ponomarenko \& Mostovski, 2005 [Afrotaldycupes africanus comb. nov.] and Afrotaldycupes lidgettoniensis (Ponomarenko in Ponomarenko \& Mostovski, 2005), comb. nov. [Taldycupes]; genus Allophalerus Kirejtshuk, gen. nov. with the type species: Tetraphalerus aphaleratus Ponomarenko, 1969 [Allophalerus aphaleratus comb. nov.], and also with Allophalerus antiquus (Ponomarenko, 1964), comb. nov. [Tetraphalerus], Allophalerus bontsaganensis (Ponomarenko, 1997), comb. nov. [Tetraphalerus], Allophalerus incertus (Ponomarenko, 1969), comb. nov. [Tetraphalerus], Allophalerus latus (Tan, Ren et Shih, 2007), comb. nov. [Tetraphalerus], Allophalerus maximus (Ponomarenko, 1968), comb. nov. [Tetraphalerus], Allophalerus okhotensis (Ponomarenko, 1993), comb. nov. [Tetraphalerus], Allophalerus tenuipes (Ponomarenko, 1964), comb. nov. [Tetraphalerus], Allophalerus verrucosus (Ponomarenko, 1966), comb. nov. [Tetraphalerus]; genus Bukhkalius Kirejtshuk et Jarzembowski, gen. nov. with the type species: Tetraphalerus lindae Jarzembowski, Wang et Zheng, 2017 [Bukhkalius lindae comb. nov.]; genus Burmocoleus Kirejtshuk, gen. nov. with the type species: Burmocoleus prisnyi sp. nov. and Burmocoleus zhiyuani (Liu, Tan, Ślipiński, Jarzembowski, Wang, Ren et Pang, 2017), comb. nov. [Brochocoleus]; genus Cionocups Kirejtshuk, gen. nov. with the type species: Cionocups manukyani sp. nov.; genus Echinocups Kirejtshuk et Jarzembowski, gen. nov. with the type species: Notocupes neli Tihelka, Huang et Cai, 2020 [Echinocups neli comb. nov.], and also Echinocups ohmkuhnlei (Jarzembowski, Wang et Zheng, 2020), comb. nov. [Notocupes] and Echinocups denticollis (Jiang, Li, Song, Shi, Liu, Chen et Kong, 2020), comb. nov. [Notocupes]; genus Jarzembowskops Kirejtshuk, gen. nov. with the type species: Brochocoleus caseyi Jarzembowski, Wang et Zheng, 2016 [Jarzembowskops caseyi comb. nov.]; genus Lobanovia Kirejtshuk, gen. nov. with the type species: Simmondsia permiana Ponomarenko, 2013 [Lobanovia permiana comb. nov.]; genus Pintolla Kirejtshuk, gen. nov. with the type species: Kaltanicupes ponomarenkoi Pinto, 1987 [Pintolla ponomarenkoi comb. nov.]; genus Polyakius Kirejtshuk, gen. nov. with the type species: Polyakius alberti Kirejtshuk, sp. nov. and Polyakius pubescens Kirejtshuk, sp. nov.; Clessidromma zengi Kirejtshuk, sp. nov.; Cupes golovatchi Kirejtshuk, sp. nov.; Cupes legalovi Kirejtshuk, sp. nov.; Cupes lutzi Kirejtshuk, sp. nov.; Cupes nabozhenkoi Kirejtshuk, sp. nov.; Cupes wedmannae Kirejtshuk, sp. nov.; Mallecupes prokini 
Kirejtshuk, sp. nov. and Omma janetae Kirejtshuk, sp. nov. The new synonymy is established for the generic names Clessidromma Jarzembowski, Wang et Zheng, 2017 and Lepidomma Jarzembowski, Wang et Zheng, 2019, syn. nov. The rank of Cainomerga A. Kirejtshuk, Nel et P. Kirejtshuk, 2016 is elevated from subgeneric to generic. Also other new combinations are proposed: Cainomerga brevicornis (A. Kirejtshuk, Nel et P. Kirejtshuk, 2016), comb. nov. [Mesocupes], Cainomerga fraterna (A. Kirejtshuk, Nel et P. Kirejtshuk, 2016), comb. nov. [Mesocupes], Cainomerga immaculata (Piton, 1940: 194), comb. nov. [Zonabris, Mesocupes], Cainomerga palaeocenica (A. Kirejtshuk, Nel et P. Kirejtshuk, 2016), comb. nov. [Mesocupes], and Cainomerga ponti (A. Kirejtshuk, Nel et P. Kirejtshuk, 2016), comb. nov. [Mesocupes], Clessidromma tianae (Jarzembowski, Wang et Zheng, 2019), comb. nov. [Lepidomma], Diluticupes applanatus (Tan et Ren, 2009), comb. nov. [Brochocoleus], Diluticupes crowsonae (Jarzembowski, Yan, Wang et Zhang. 2013), comb. nov. [Brochocoleus], Diluticupes magnus (Tan et Ren, 2009), comb. nov. [Brochocoleus], Diluticupes minor (Ponomarenko, 2000), comb. nov. [Brochocoleus], Diluticupes validus (Tan et Ren, 2009), comb. nov. [Brochocoleus], Diluticupes yangshuwanziensis (Jarzembowski, Yan, Wang et Zhang. 2013), comb. nov. [Brochocoleus], Monticupes curtinervis (Tan, Ren et Shih, 2007), comb. nov. [Tetraphalerus], Monticupes decorosus (Tan, Wang, Ren et Yang, 2012), comb. nov. [Tetraphalerus], Odontomma sulcatum (Tan, Ren et Shih, 2007), comb. nov. [Brochocoleus], Omma ancistrodontum (Tan, Wang, Ren et Yang, 2012), comb. nov. [Pareuryomma], Omma grande (Ponomarenko, 1964), comb. nov. [Tetraphalerus], Omma longicolle (Ponomarenko, 1997), comb. nov. [Tetraphalerus], Pareuryomma angustum (Tan, Ren et Shich, 2007), comb. nov. [Brochocoleus], Pareuryomma magnum (Tan et Ren, 2009), comb. nov. [Brochocoleus], Zygadenia aliena (Tan et Ren, 2006), comb. nov. [Ovatocupes], Zygadenia baojiatunensis (Hong 1992), comb. nov. [Chengdecupes], Zygadenia brachycephala (Ponomarenko, 1994), comb. nov. [Notocupes], Zygadenia caduca (Ponomarenko, 1969), comb. nov. [Notocupes], Zygadenia caudata (Ponomarenko, 1966), comb. nov. [Notocupes], Zygadenia cellulosa (Ponomarenko, 1969), comb. nov. [Notocupes], Zygadenia crassa (Ponomarenko, 1969), comb. nov., [Notocupes], Zygadenia cyclodontus (Tan, Ren, Shih et Ge, 2006), comb. nov. [Amblomma, Notocupes], Zygadenia dischdes (Zhang, 1986), comb. nov. [Notocupes], Notocupes dundulaensis (Ponomarenko, 1994), comb. nov. [Notocupes], Zygadenia elegans (Ponomarenko, 1994), comb. nov. [Notocupes], Zygadenia epicharis (Tan, Ren et Liu, 2005), comb. nov. [Amblomma, Notocupes], Zygadenia eumeura (Tan, Ren et Liu, 2005), comb. nov. [Amblomma, Notocupes], Zygadenia excellens (Ponomarenko, 1966), comb. nov. [Notocupes], Zygadenia exigua (Ponomarenko, 1994), comb. nov. [Notocupes], Zygadenia foersteri (Ponomarenko, 1971), comb. nov. [Procarabus, Notocupes], Zygadenia homora (Lin, 1986), comb. nov. [Conexicoxa, Notocupes], Zygadenia issykkulensis (Ponomarenko, 1969), comb. nov. [Notocupes], Zygadenia jurassica (Hong 1983), comb. nov. [Chengdecupes], Zygadenia kezuoensis (Hong 1987), comb. nov. [Chengdecupes], Zygadenia khasurtuiensis (Strelnikova, 2019), comb. nov. [Notocupes], Zygadenia khetanensis (Ponomarenko, 1993), comb. nov. [Notocupes], Zygadenia kirghizica (Ponomarenko, 1969), comb. nov. [Notocupes], Zygadenia laeta (Lin, 1976), [Tetraphalerus], Zygadenia laiyangensis (Hong et Wang, 1990), comb. nov. [Forticupes, Notocupes], Zygadenia lapidaria (Ponomarenko, 1968), comb. nov. [Notocupes], Zygadenia laticella (Ponomarenko, 1969), comb. nov. [Notocupes], Zygadenia lata (Ponomarenko, 1969), comb. nov. [Notocupes], Zygadenia lenta (Ren, Lu, Guo et Ji, 1995), comb. nov. [Tetraphalerus], Zygadenia lini (Ponomarenko, Yan, Wang et Zhang, 2012), comb. nov. [Notocupes], Zygadenia longicollis (Ponomarenko, 1994), comb. nov. [Notocupes], Zygadenia ludongensis (Wang et Liu, 1996), comb. nov. [Notocupes], Zygadenia minuscula (Tan, Ren, Shih et Ge, 2006), comb. nov. [Amblomma, Notocupes], Zygadenia mongolica (Ponomarenko, 1994), comb. nov. [Notocupes], Zygadenia nigrimonticola (Ponomarenko, 1968), comb. nov. [Notocupes], Zygadenia oxypyga (Ponomarenko, 1969), comb. nov. [Notocupes], Zygadenia patula (Ponomarenko, 1985), comb. nov. [Notocupes], Zygadenia pingi (Ponomarenko et Ren, 2010), comb. nov. [Notocupes], Zygadenia porrecta (Tan, Ren, Shih et Ge, 2006), comb. nov. [Amblomma, Notocupes], Zygadenia protensa (Tan, Ren, Shih et Ge, 2006), comb. nov. [Amblomma, Notocupes], Zygodenia psilata (Tan, Ren et Liu, 2005), comb. nov. [Amblomma, Notocupes], , Zygadenia pulchra Ponomarenko, 1968, comb. nov. [Notocupes], Zygadenia reticulata (Oppenheim, 1888), comb. nov. [Procarabus, Notocupes], Notocupes rostrata (Ponomarenko, 1969), comb. nov. [Notocupes], Zygadenia rudis (Tan, Ren et Liu, 2005), comb. 
nov. [Amblomma, Notocupes], Zygadenia shiluoensis (Hong 1984), comb. nov. [Chengdecupes], Zygadenia sogutensis (Ponomarenko, 1969), comb. nov., Zygadenia stabilis (Tan, Ren et Liu, 2005), comb. nov. [Amblomma, Notocupes], Zygadenia tenuis (Ponomarenko, 1969), comb. nov. [Notocupes], Zygadenia tripartita (Oppenheim, 1888), comb. nov. [Procarabus, Notocupes], Zygadenia tuanwangensis (Hong et Wang, 1990), comb. nov. [Picticupes, Notocupes], Zygadenia valida (Lin, 1976), comb. nov. [Sinocupes, Notocupes], Zygadenia vitimensis (Ponomarenko, 1966), comb. nov. [Notocupes].

Keywords: fossil record; distribution in space and time; new genera; new species; new synonymy; taxonomic composition

\section{Introduction}

This publication is the first of a series, which aims to provide a consistent interpretation of the suprageneric taxa of fossil beetles in the current century and their generic and species composition. The preparation of such an attempt is quite complicated, because probably no recent palaeocoleopterist can be competent in all groups of the order. Another great problem is to find a reasonable compromise between alternative opinions on the placement of established taxa proposed by somebody. The author of this publication is aware of a lot of complexities in the attempt undertaken by him and possible criticism from many other researchers who are more experienced in many groups of the order studied by the present author. A serious particular problem is connected with correct interpretation of the previous descriptions and illustrations supplementing them, most of which contains rather ambiguous or inadequate information on the described forms. In most cases the formerly described species need to be retested and redescribed for a correct usage. Nevertheless, the general importance of such understanding is they can provide preliminary generalizations to put together a great quantity of facts obtained by the author and borrowed from literature in order. Many years of previous debates on this matter among neontologists and palaeontologists clarified several complex problems but were not enough to produce a balanced result. However, even taking into consideration the deficiencies published in the previous taxonomic generalizations on fossil beetles, such as Handlirsch [1], Rohdendorf [2], Carpenter [3] and others, it is difficult to overestimate their significance in research and usage in different fields of knowledge. In recent decades, publication of numerous separate annotated lists of fossil beetles on separate groups or palaeofaunas provided many very important contributions (for examples, reviews and catalogues [4-23], and many others).

Ponomarenko and Zherikhin, palaeocoleopterists of the Paleontological Institute of the Russian Academy of Sciences, prepared the "catalogue" (a filing cabinet including many carboard cards with used or proposed names for fossil beetles), later Ponomarenko put a considerable part of this information in some computer DOC-files. The next step of development of the basis for this publication was a preparation of the "Catalogue of fossil Coleoptera" presented on the site of "Beetles (Coleoptera) and coleopterists" of the Zoological Institute of the Russian Academy of Sciences (https://www.zin.ru/animalia/coleoptera/rus/index.htm). This preparation was made in 2002 and 2003 with the very essential contribution of Lobanov who helped to find a way presenting this "catalogue" on the Internet and after that Lobanov devoted years in adding new data and correcting previous data in the web-pages. Participation of Ponomarenko in preparation of the web-version of this catalogue during few first years was rather essential, however, later he could not find time for contribution in the development of this catalogue and, as a result, many important corrections and changes in it were made without his attention and agreement. Nevertheless an initial impulse of collecting of taxonomic facts from palaeontological literature to put them in Internet appeared thanks to the Ponomarenko's desire to save the data of carboard cards for use by colleagues from over the world.

During the current century other resources of data on fossil beetles appeared and got a rather quick development. One of most important and a rather large source of different palaeontological 
information is the web-site "FOSSILWORKS. Gateway to the paleobiology database" (fossilworks.org/) containing the information not only on many fossil taxa, but also various information on different aspects, including data on the geological circumstances of the localities where each taxon was collected, localization of specimens which gave the base for proposals of numerous fossil taxa and which were published after the description of each definite taxon included in this database, geographic and stratigraphic distribution of each taxon, summary of classification aspect of supraspecific taxa, and much other valuble information. At the moment, however, there are still many coleopterous groups remaining out of this resource and this attempt to fill some information gaps is thought to be useful for further progress of the investigation of fossil beetles. On the other hand, there are some wrong taxonomic interpretations occasionally included in the database "FOSSILWORKS". Another web-site very useful for searching general information on fossil taxa recently published is a web-series of Wikipedia "in insect paleontology" (https://en.wikipedia.org/wiki/2019_in_insect_paleontology) and the "Index of organism names" (http://www.organismnames.com/), however, both these sources are useful mostly for getting only basic reference data on published taxa. Having summarized these parental efforts, the author of this publication hopes that it will cause a further discussion and draw the attention of other colleagues, who, in turn, will make essential contributions to reach a good reasonable taxonomic interpretation of the fossil data on the order Coleoptera.

The appearance of a great interest and very rapid increase of data on fossils during recent decades created a situation when addition of new facts occurred much faster than their conceptualization in general theoretical aspects. On the other hand, every year many papers proposing new hypotheses using fossils as a part of their base have appeared. Thus, correct interpretations of the fossil record including correct taxonomic interpretation of fossils considered have a major significance, not only for classification of these fossils but also for different evolutionary applications. As one such instance, calibration with use of fossils for cladistic and molecular modeling can be taken. Two models of phylogenetic relations between coleopterous groups using the same molecular data with a little difference in the software but with different extinct taxa taken for callibrations were published and gave rather different results [24,25]. Regardless of the discussion of these differences by the researchers involved, it can be imagined what will emerge if a third set of fossils assembled for the next attempt at modeling. This circumstance demonstrates importance of adequate results of paleontological research. Nevertheless, the author of this publication prefers to concentrate his attention mostly on taxonomic aspects, without which every theoretical reconstruction has a risk of becoming ungrounded speculation. The author of this publication has tried to restrict the possibilities of such situations.

Subsequent taxonomic interpretation of large groups with rank above family can be partly found in many papers by Ponomarenko [26,27]; etc. and Kirejtshuk [28], but the general division of the archostematans was kept as in litteris. Later this division was preliminarily put on the web-site of the Zoological Institute of the Russian Academy of Sciences "Beetles (Coleoptera) and coleopterists" [29,30], but it was not published in a paper. Some authors introduced these Ponomarenko proposals in a somewhat coleopterological tradition [31-33], although the reason for them remained unpublished. In this publication some main arguments for joining archostematans into superfamilies are preliminarily included, and complete sets of reasons for them need to be established after further studies of new material and re-examination of material studied by former researchers.

This publication aims to summarize data on fossils in a consistent interpretation as a review of the family groups with a list of genera represented in fossils with some comments to the peculiarities of this interpretation. The preparation of this paper was carried out with new additional changes to these web-pages. Generic and species taxa of unclear position are listed in these web-pages, although in cases where current examination or re-examination made it possible to clarify their interpretation, the explanation of these cases is included in this publication. 


\section{Repositories}

CNU_Capital Normal University, Beijing, China

GPIH-Center of Natural History (formerly Geological-Paleontological Institute and Museum), Hamburg, Germany

LNNR - Naturhistorisches Museum, Landessammlung für NaturLandessammlung für Naturkunde Rheinland-Pfalz, Mainz, Germany

MNHN_Muséum National d'Histoire Naturelle, Paris, France

PIN-Palaeontological Institute of the Russian Academy of Sciences, Moscow, Russia

PrFUK-Institute of Geology and Palaeontology at the Charles University in Prague, Czech Republic SFNFM-Senckenberg Forschungsinstitut und Naturmuseum Forschungsstation Grube, Messel, Germany

ZfB-Zentrum für Biodokumentation des Saarlandes, Am Bergwerk Reden 11, 66578 Schiffweiler, Germany

ZIN-Zoological Institute of the Russian Academy of Sciences, St. Petersburg, Russia

ZMUC-Zoologisk Museum at Copenhagen University, København, Denmark.

\section{Material and Methods}

Besides the material from the organizations listed in the above repositories, many specimens from the palaeofaunas and modern fauna were studied in many collections which are not easy to list and therefore, the author prefers to mention a useful collection in every case out of necessity.

The photographs of the general appearance (habitus) were taken with a EOS $1140 \mathrm{D}$ digital camera (Canon, Tokyo, Japan) equipped with a Canon MP-E $65 \mathrm{~mm}$ objective and were combined using Zerene Stacker 1.04 software (Zerene Systems LLC, Richland, WA, USA). The fluorescent microscopic images were taken using a DM 6000B microscope (Leica Microsystems GmbH, Wetzlar, Germany) with 2.5× and 5× objectives, Leica DFC 345 FX camera and Leica Application Suite 3.7 software with an Image MultiFocus module (Leica). The filter set applied was in most cases N21 or sometimes L5 (Leica Microsystems). The pictures of specimens from SFNFM and LNNR were taken by Sonja Wedmann (SFNFM) and Herbert Lutz (LNNR).

Many theoretical problems are connected with different taxonomic interpretations and classificational constructions proposed in accordance with some peculiarities of the theoretical concept accepted by their authors. The current studies have been based mostly on viewpoints by Rohdendorf [2], Ponomarenko [26] and Crowson [34] based on data from many fossil taxa and many modern groups personally studied by them in different collections.

Only the generic and specific taxonomic names are provided with correspondent references. Divisions of many families are provided with some notes on taxonomic interpretations of the names included in the corresponding family (including notes on synonymy) and a list of names excluded from this family. In cases of proposals of new taxa or new synonymy each proposal is provided with corresponding information (including the necessary diagnosis, materials examined, description, argumentation for synonymy). The author determined the age of the specimens under consideration from the site FOSSILWORKS and the International Chronostratigraphic Chart published by the International Commission on Stratigraphy in 2018 on Internet (www.stratigraphy.org) and, if the divisions of this chart differs from the General Statigraphic Scale published by the Interagency Stratigraphic Committee (Saint Petersburg) in 2019 on the Internet (https://vsegei.ru/ ru/info/stratigraphy/stratigraphic_scale/str_scale5_preview.jpg), the division of the latter is given in parentheses after the division of the International Commission.

The nomenclature of elytral veins used in this paper was discussed in detail by Kirejtshuk et al. [32,33]. Ponomarenko in his publications on archostematans used the terms "primary" and "intercalary" veins for interspaces between longitudinal rows of cells. The primary veins, if they present, can be more or less definitely recognized, because it is possible to trace their associations with the tracheal system, while other thickenings of the elytral integument have, like the initial elytral venation, 
also a certain mechanical ground for appearance but different from those of the "primary" veins [32]. In permocupedids and cupedids the reduction of expression of the primary veins makes the interspaces between the longitudinal rows of cells comparable, however it has no real reason to define the interspaces between paired longitudinal rows not associated with the rudiments of the primary veins as "intercalary" veins. On the other hand, destruction of the elytral integument sometimes produces a similar sculptural character in the remnants of the primary veins and thickened interspaces between the longitudinal rows of cells giving an impression at least on the similar morphological base. Nevertheless in this publication the author tried to avoid such contradistinction of the "veins", which can produce confusion in interpretation and understanding, and, therefore, only the primary veins are recognized as veins and interspaces between paired longitudinal rows of cells are not here accepted as veins.

The author took in his consideration that during the late Palaeozoic the south and north continental plates were still consolidated in Pangea; however, the distance between the south of pre-Africa and the pre-Asian plates at that time was rather great and these places were characterized by different floras disunited by a very large area (Euramerian Floral Region) between the Angara and Gondwana [35]. Thus it is reasonable to expect that "formal" or "collective" genera ("morphogenera") with some structural differences belong to different supraspecific taxa rather than to the same one. In case if difference between species of related groups are observable the author prefers to erect separate generic taxa for relatives from isolated northern and southern areas in the Angara and Gondwanan regions.

Many genera and species remained out the lists of taxa proposed as members of the families here considered but having unclear or wrong position will be included in the further part on Archostemata.

\section{Systematic Part}

Superorder Coleopteroidea Handlirsch, 1903

(Elytrophora Packard, 1883 (non Elytrophora Gerstaecker, 1853); Coleopterida sensu Boudreaux, 1979, nec Pearse, 1936)

Comments. The usage of the name Coleopterida for designation of a superorder began in the second half of the 20th century and before it was used sometimes as an equivalent of the name Coleoptera (for example, Pearse [36] modified (in a uniform way) all higher taxa of insects: Diptera became Dipterida, Strepsiptera-Strepsipterida, Coleoptera-Coleopterida, Adephaga-Adephagina and so on). In 1903 Handlirsch [37] proposed a subclass Coleopteroidea with a clear indication of this taxonomic act ([37]: 732-“'Unterclasse. Coleopteroidea m.") that united the orders Coleoptera and Strepsiptera. Later this taxon was also used as a superorder by Rohdendorf ([2]: 392- “НадотрядСoleopteroidea. Жесткокрылые”; [38]; etc.). During the last few decades the name of this taxon of superordinal rank (superorder or cohort), contrary to the principle of priority, was changed on "Coleopterida" [39,40]; etc. Recently the Carboniferous order Skleroptera (Figure 1A) was added to this superorder ([41,42]: Stephanastidae Kirejtshuk et Nel, 2013: Stephanastus polinae Kirejtshuk et Nel, 2013: France (Commentry); Carboniferous, Pennsylvanian, Gzhelian (Upper Carboniferous, Gzhelian), -303.4-298.9 Ma). Besides, the family Umenocoleidae (Umenocoleus sinuatus Chen and T'an, 1973 [43] (China: Gansu, (Huitongbao, Yumen City); Lower Cretaceous, Albian, -112.6-99.7 Ma) and (U. nervosus Zhang, 1997 [44]; China: Jilin (Zhixin Forest Farm); Lower Cretaceous, Aptian, -125.5-112.6 Ma) could possibly be linked with this superorder if a further study will confirm the synapomorphies with this superorder. The most important characteristics shared by Skleroptera, Coleoptera and Umenocoleus, to the exclusion of all other holometabolous orders, include (Figures 1 and 2): Sc simple and somewhat reduced; simple concave RP and convex RA; M less convex than R and $\mathrm{CuA}, \mathrm{M}$ also simple, and basally fused with $\mathrm{CuA}$ (putative synapomorphy), but distally separating from it; stem of $M+C u$ well separated from R. Finally, some other fossils seem to have a relationship to coleopterous groups; however, at the moment their taxonomic interpretation is impossible because there are contradictions in the available characteristics (for example, "Moravocoleus" perditus Kukalová, 1969 [45]-see below). 

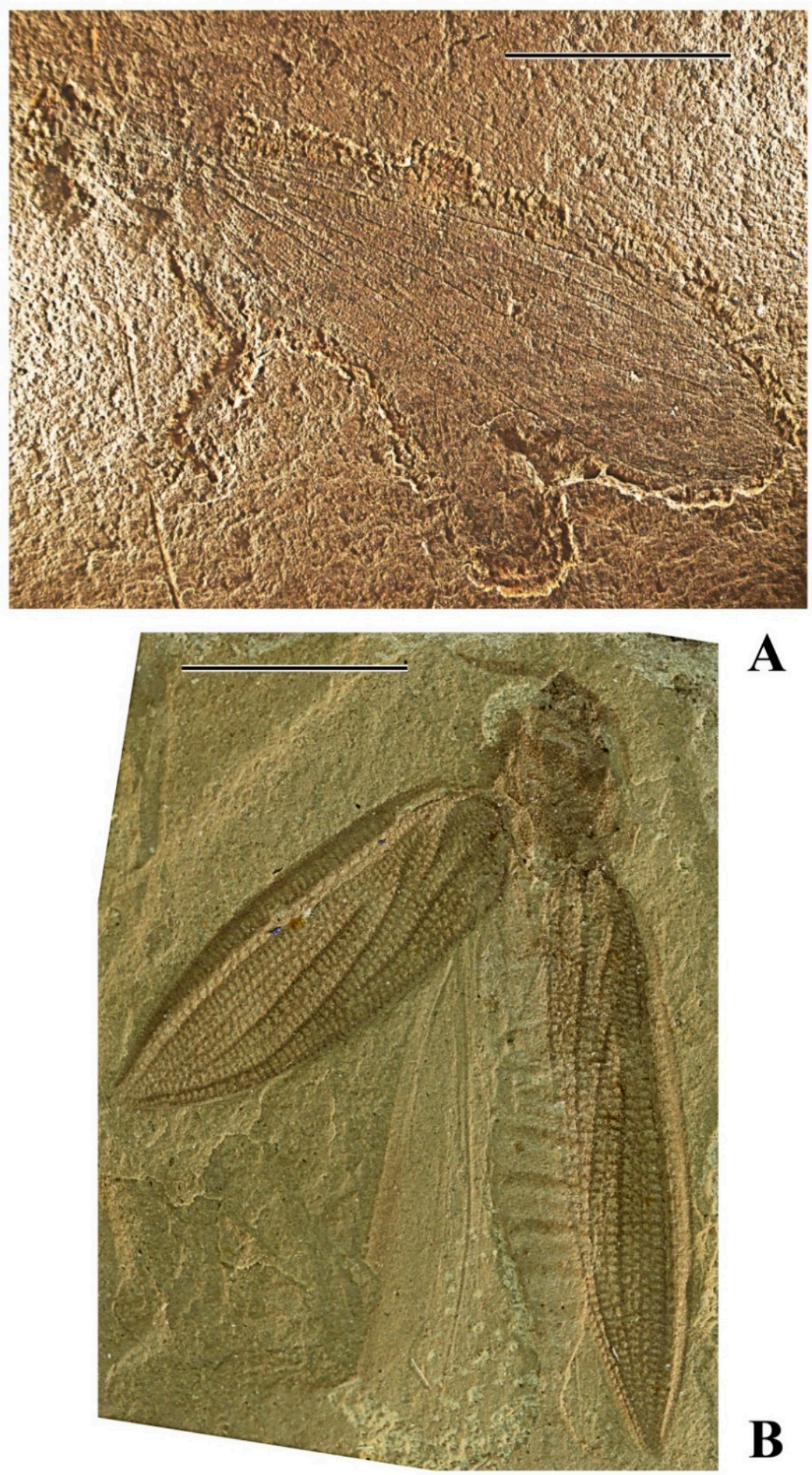

A

Figure 1. Stephanastidae (Skleroptera) and Tshekardocoleidae (Coleoptera): A-Stephanastus polinae, holotype MNHN.A.49011 (Carboniferous: Gzhelian; Commentry, Allier), length of print $28.0 \mathrm{~mm}$, scale bar $=8.0 \mathrm{~mm}$; after Kirejtshuk \& Nel [19] with changes. B-Moravocoleus permianus, holotype PrF UK: 1/1968 (Permian: Cisuralian, Sakmarian; Moravia, Obora), length of print $7.9 \mathrm{~mm}$, scale bar $=2.4 \mathrm{~mm}$; from http://www.zin.ru/Animalia/Coleoptera/rus/moravoco.htm. 


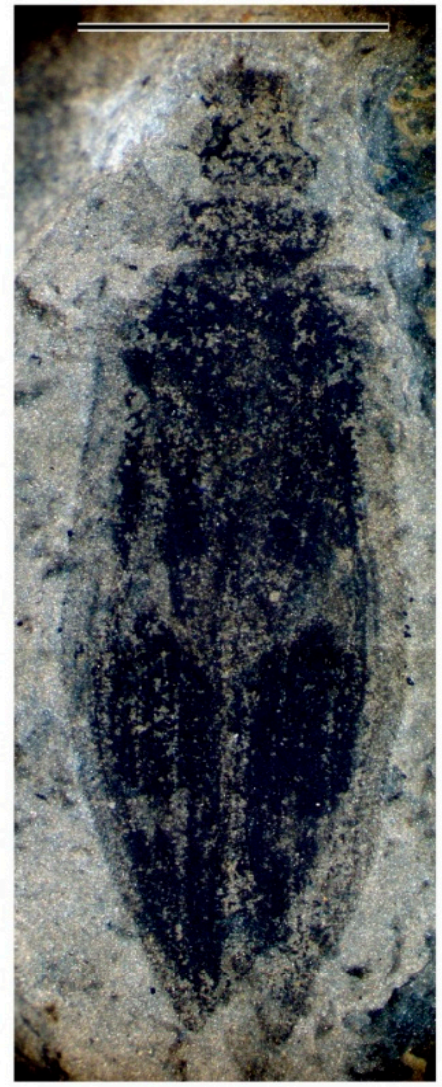

A

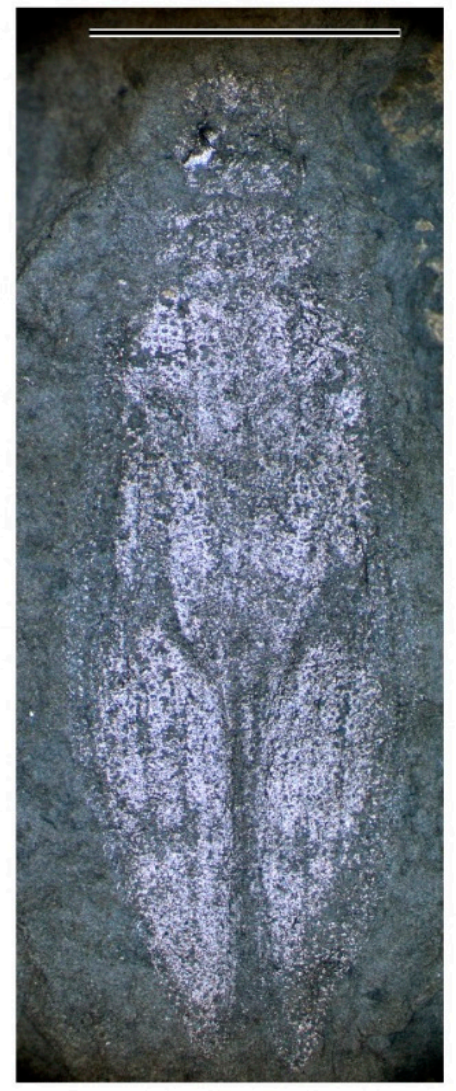

B

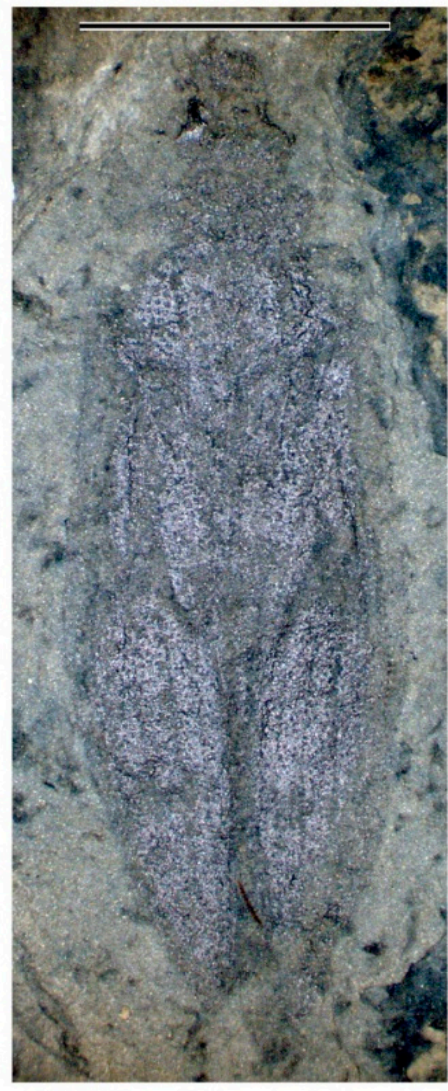

C
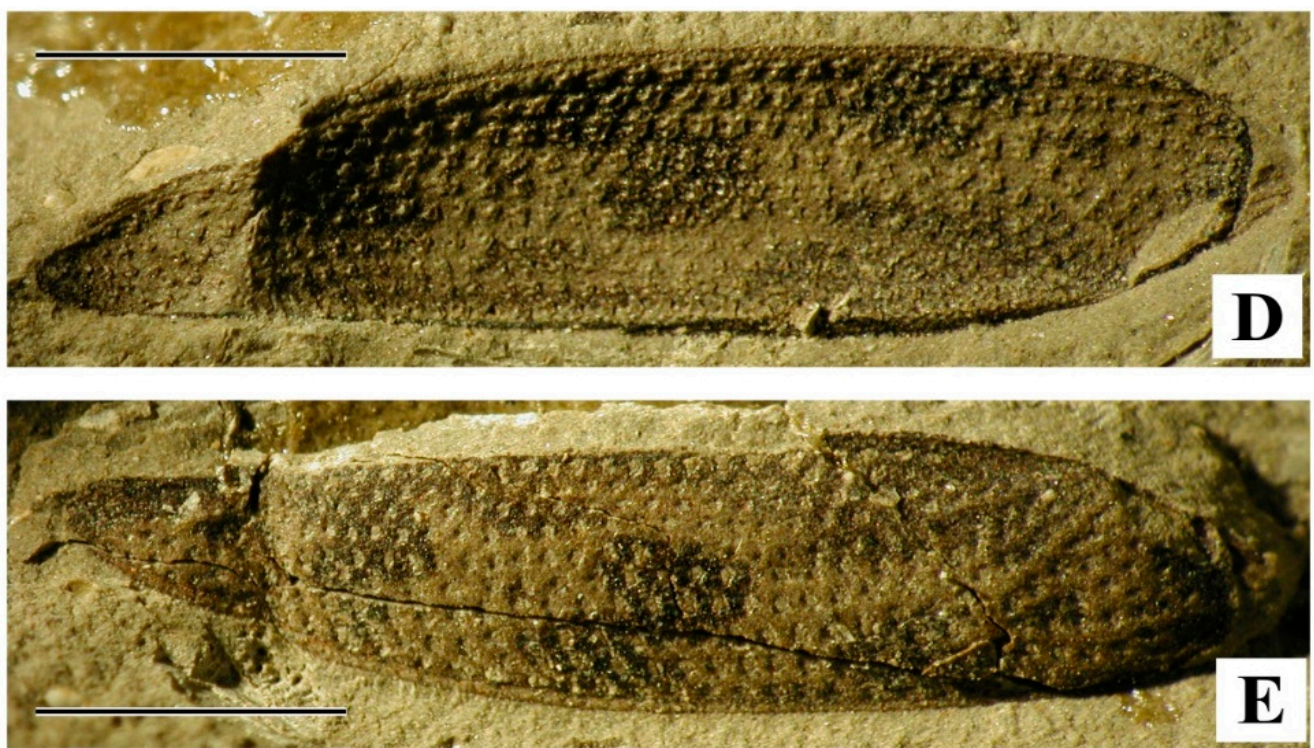

Figure 2. Coleopseidae and Permocupedidae: A-C-Coleopsis archaica, holotype ZfB 3315 (Permian: Asselian-Sakmarian; Saarland, Grügelborn): part, body immersed in alcohol (isopropanol); A-with polarizing filters completely crossed (with linear polarized light completely extinct); B —without crossing polarizing filters; $\mathbf{C}$-with polarizing filters approximately halfway crossed; length of print $7.8 \mathrm{~mm}$, scale bar = $2.5 \mathrm{~mm}$; from http://www.zin.ru/Animalia/Coleoptera/rus/coleopsi.htm. D-E-Tatarocupes granulatus, holotype PIN 3700-34 (Permian, Guadalupian/Lopingian, Capitanian/Wuchiapingian; Orenburg Region, Novo-Aleksandrovka): D-counterpart, E-part; length of print $8.0 \mathrm{~mm}$, scale bar $=2.0 \mathrm{~mm}$; from http://www.zin.ru/Animalia/Coleoptera/rus/tatarcup.htm. 
Order Coleoptera Linnaeus, 1758

(= Eleuterata Fabricius, 1775; Scarabaeida Laicharting, 1781; Coleopterida Pearse, 1936; etc.)

Comments. The widely recognized name of the order (Coleoptera) was introduced in science by Aristotle, who apparently included in it all winged insects with hardly sclerotized forewings (elytra, tegmina). With this meaning the name was used by Linnaeus [46], i.e., it was applied to beetles, earwigs, cockroaches, mantises etc. On the other hand, many names were for this order (e.g., Heteroptera Burmeister, 1835 [47], non Latreille, 1810, Coleopterida Pearse, 1936 [36], Erytraria Machatschke, 1962 [48], etc.). The classification of this order has some different interpretations. In this publication the following traditional suborders are recognized: Archostemata, Myxophaga, Adephaga and Polyphaga, proposed by Crowson [49] for beetles, although many problems still remain with general partition of the suborders and attribution of various groups, particularly some fossil ones (extinct families and genera).

The oldest finds of beetles in the fossil record are in time at the boundary of the Carbonifeous and Permian (families Coleopseidae and Tskekardocoleidae). The available representatives of these families demonstrate a complete set of apotypic characteristics of the order Coleoptera available in compression fossils [32,33]. Therefore, it is reasonable to suppose that the appearance of the order and its early diversifications happened before the Permian.

Suborder Archostemata Kolbe, 1908

(= Protocoleoptera auctorum, non Tillyard, 1924; Archecoleoptera Crowson, 1981: see Kirejtshuk et al., 2014 [32])

Comments. Kirejtshuk in 1991 [28] proposed to divide the Archostemata (modern and fossil) into Cupediformia and Micromaltiformia, while among extint groups to distinguish Schizophoriformia. Later Ponomarenko in 2002 [27] split Archostemata into two groups, Cupedomorpha and Schizophoromorpha (latter including Micromalthidae and Microsporoidea = Myxophaga). The relationship between Archostemata and Microsporoidea = Myxophaga needs further investigation, and in this series of publications the latter group is still regarded as a separate suborder that corresponds with the widely recognized opinion in neontological coleopterology $[49,50]$ etc. Following the principle of priority the Archostemata is here accepted as consisting of three infraorders, Cupediformia Lameere, 1903 [51], Micromalthiformia Kirejtshuk, 1991 [28] and Schizophoriformia Kirejtshuk, 1991 [28]. The recent discovery of a micromalthiformian in the Permian [52] supports such an interpretation of this group.

Infraorder Cupediformia Lameere, 1903

(= Cupedomorpha Ponomarenko, 2002)

Comments. Lameere [51] and some other coleopterists regarded the name Cupediformia as a synonym of Archostemata as a whole. In the current interpretation this infraorder is the oldest among beetle infraorders and also seems to be the most archaic in the fact that it maintains the remains of the "archedictyon" and primary membrane in cells ("window punctures") in the forewings of most families. This was a reason to join tshekardocoleids with the polyneopteran lineage $[45,53]$. In some cases the forewing venation of polyneopterans and coleopteroids is so similar that it requires a rather delicate analysis for a correct identification [32,41,42,54], etc. Four supefamilies are currently placed in this infraorder, viz., Coleopseoidea, Cupedoidea, Crowsonelloidea and Jurodoidea, two of which are characterized by the more or less traceable remnants of the "archedictyon" and primary membrane in their elytra. At the same time, the recent monotypic genus Crowsoniella Pace, 1976 [55] has many similarities in structure of its head and thorax with those in archostematans, particularly in ommatines from Cupediformia [56]; but its elytra lack any trace of both venation and cells and some other organs are partly similar to those of other beetle infraoders [57]. Also, there are some problems in the systematic placement of the taxon Jurodidae Ponomarenko, 1985 [8]. Kirejtshuk [58] emphasized 
the abdominal structure (particularly on the ventrite 1 and genital capsule in Sikhotealinia Lafer, 1996 [59]) and the structure of the pterothorax which are reminiscent of those in cupedids, but other coleopterists referred to other structures (for example, hind wing venation) and found some other explanations $[60,61]$. Among other things the six exposed ventrites of jurodids are still a problem for the phylogenetic interpretation of this family. Therefore, despite some ambiguity between the different opinions, jurodids are maintained in the archostematan Cupediformia as a separate superfamily.

Superfamily Coleopseoidea Kirejtshuk et Nel, 2016

Notes. This superfamily was proposed because its unique member has the remnants of the elytral "archedictyon" to a greater extent than that in tshekardocoleids but, on the other hand, its elytra, in contrast to tshekardocoleids, have only rudiments of the primary membrane in some places, while a considerable part of the elytral integument apparently has a "normal" punctation or very small oval cells ("window punctures") [32,62]. Besides, Coleopsis is characterized by R branching in the distal half of the elytra, producing three veins at the apices; $\mathrm{CuA}(+\mathrm{M})$ branching into $\mathrm{CuA}$ and $\mathrm{M}$ at the middle of the elytra; and CuP fusing with the first anal vein at the elytral base.

The archaic groups of Cupedoidea, alternatively, have fewer traces of the "archedictyon" in the venation of the elytra, but well expressed primary membrane in the cells of the elytra is well expressed [32,62]. Most cupedoids demonstrate trends of progressive simplification of the elytral venation and reduction of the primary membrane with disloging of cells by regular punctures or microtubercles $[45,53]$; etc.

Family Coleopseidae Kirejtshuk et Nel, 2016

(lapsus calami: Coleopsidae Kirejtshuk et Nel, 2016)

Type genus: Coleopsis Kirejtshuk, Poschmann et Nel in Kirejtshuk et al., 2014 [32], fossil; Permian, Cisuralian; Germany: Saarland.

(one genus, one species)

Genus Coleopsis Kirejtshuk, Poschmann et Nel in Kirejtshuk et al., 2014 [32] (Figure 2A-C). Type species: Coleopsis archaica Kirejtshuk, Poschmann et Nel in Kirejtshuk et al., 2014 [32], by monotypy. One species. Germany: Saarland, Grügelborn, Permian, Cisuralian, Asselian-Sakmarian, -298.9-295.0 Ma.

Superfamilia Cupedoidea Laporte, 1836

(= Permocupedoidea Martynov, 1932, Tshekardocoleoidea Rohdendorf, 1944)

Comments. This group together with Coleopseoidea are characterized by the elytral venation and sculpture (including peculiarities of vestiture) most similar to those of the most ancient (and likely the initial) of the order, although in the more derived members these structural peculiarity could be rather modified. These characteristics are most expressive and frequently observable in fossil remains (represented mainly by isolated elytra) and, therefore, more important for palaeocoleopterology. Unfortunately, the fossil remains of the body and its appendages with diagnostic features to make study possible are rather rare. All known fossil bodies of the cupedoids with reliable attribution demonstrate a great level of uniformity, making correct attributions to precise superfamily possible (see also the Comments to the superfamily Coleopseoidea above).

Family Tshekardocoleidae Rohdendorf, 1944

Type genus: Tshekardocoleus Rohdendorf, 1944 [63], fossil; Permian, Cisuralian; Russia: Perm' Region (Tshekarda).

(= Uralocoleidae Zalesskiy, 1947, type genus: Uralocoleus Zalesskiy, 1947 [64]; Moravocoleidae Kukalová-Peck et Beutel, 2012 [65], type species: Moravocoleus Kukalová, 1969: see [26,32])

(12 genera, 15 species) 
Comments. A short review of the genera of this family was published by Kirejtshuk et al. [32].

Genus Avocoleus Ponomarenko, 1969 [26]. Type species: Moravocoleus fractus Kukalová, 1969, by original designation [45]. Two species.

Congeners: Avocoleus fractus [Moravocoleus] [45], Avocoleus neglegens (Kukalová, 1969) [Moravocoleus] [45].

Czech Republic: Moravia (Obora), Permian, Cisuralian, Sakmarian, -295.0-290.1 Ma.

Genus Boscoleus Kukalová, 1969 [45]. Type species: Boscoleus blandus Kukalová, 1969 [45], by monotypy. One species.

Czech Republic: Moravia (Obora), Permian, Cisuralian, Sakmarian, -295.0-290.1 Ma.

Genus Eocoleus Kukalová, 1969 [45]. Type species: Eocoleus scaber Kukalová, 1969 [45], by monotypy. One species.

Czech Republic: Moravia (Obora), Permian, Cisuralian, Sakmarian, -295.0-290.1 Ma.

Genus Moravocoleus Kukalová, 1969 [45]. Type species: Moravocoleus permianus Kukalová, 1969 [45] (Figure 1B), by original designation. One species.

Czech Republic: Moravia (Obora), Permian, Cisuralian, Sakmarian, -295.0-290.1 Ma.

Genus Permocoleus Lubkin et Engel, 2005 [66]. Type species: Permocoleus wellingtoniensis Lubkin et Engel, 2005 [66], by monotypy. One species.

USA: Oklahoma, Noble County (Midco Locality and Tasch Nobel V, Bed 7), Permian, Cisuralian, Sakmarian-Artinskian -290.1-279.5 Ma.

Notes. The genus Permocoleus was initially proposed without any family attribution but with a mention of its similarities to Kaltanicupes ponomarenkoi Pinto, 1987 [67] (currently the latter species is in the genus Pintolla gen. nov., see below) in Permocupedidae Martynov, 1932 [66-68]. Its attribution to Tshekardocoleidae was established by Kirejtshuk et al. [32].

Genus Prosperocoleus Kukalová, 1969 [45]. Type species: Prosperocoleus prosperus Kukalová, 1969 [45], by monotypy. One species.

Czech Republic: Moravia (Obora), Permian, Cisuralian, Sakmarian, -295.0-290.1 Ma.

Genus Retelytron Kukalová, 1965 [45]. Type species: Retelytron conopeum Kukalová, 1965 [45], by monotypy. One species.

Czech Republic: Moravia (Obora), Permian, Cisuralian, Sakmarian, -295.0-290.1 Ma.

Genus Sylvacoleodes Ponomarenko, 1963 [69]. Type species: Sylvacoleodes admirandus Ponomarenko, 1963 [69], by monotypy. One species.

Russia: Perm' Region, Suksun (Tshekarda, Sylva River), Permian, Cisuralian, Artinskian-Kungurian, -279.5-272.5 Ma.

Genus Sylvacoleus Ponomarenko, 1963 [69]. Type species: Sylvacoleus richteri Ponomarenko, 1963 [69], by original designation. Two species.

Another congener: Sylvacoleus sharovi Ponomarenko, 1963.

Russia: Perm' Region, Suksun (Tshekarda, Sylva River), Permian, Cisuralian, Artinskian-Kungurian, -279.5-272.5 Ma.

Genus Tshekardocoleus Rohdendorf, 1944 [63]. Type species: Tshekardocoleus magnus Rohdendorf, 1944 [63], by monotypy. Two species.

Another congener: Tshekardocoleus minor Ponomarenko, 1963 [69].

Russia: Perm' Region, Suksun (Tshekarda, Sylva River), Permian, Cisuralian, Artinskian-Kungurian, -279.5-272.5 Ma.

Genus Umoricoleus Kukalová, 1969 [45]. Type species: Umoricoleus perplex Kukalová, 1969 [45], by monotypy. One species. 
Czech Republic: Moravia (Obora), Permian, Cisuralian, Sakmarian, -295.0290.1 Ma.

Genus Votocoleus Kukalová, 1969 [45]. Type species: Votocoleus submissus Kukalová, 1969 [45], by monotypy. One species.

Czech Republic: Moravia (Obora), Permian, Cisuralian, Sakmarian, -295.0-290.1 Ma.

\section{Notes on the Family Tshekardocoleidae}

The placement of "Moravocoleus" perditus Kukalová, 1969 [45] (Czech Republic: Moravia (Obora); Lower Permian, Sakmarian -295.0-290.1 Ma) was revised by Kirejtshuk et al. [32]. At the moment this species is regarded outside the proposed archostematan families because of conflicts in its characteristics, i.e., availability of at least six exposed abdominal ventrites, a considerable general similarity with other tshekardocoleids plus also some similarity in the forewing venation and cells. The correct placement of this species needs the study of a specimen of a taxon closely related to "Moravocoleus" perditus but better preserved.

Some mentions of tshekardocoleids in Hörnschemeyer (1999) [70], Kirejtshuk et al. [32], etc. actually concern the family Coleopseidae.

The genus Dictyocoleus Hong, 1982 [71] (= Dictycoleus Hong, 1982, lapsus calami) (type species: Dictyocoleus jurassicus Hong 1982 [71], by monotypy; China: Gansu Province (Hongliu Geda, Subei County), Jurassic, Aalenian-Bajocian, -175.6-167.7 Ma). Hong (1982) proposed the name Dictyocoleus jurassicus for one elytron, which, according to his drawing-reconstruction, has its venation somewhat similar to that in tshekardocoleids: $\mathrm{M}+\mathrm{CuA}$ joined at base distally separated and at a small distance from this separation $\mathrm{M}$ is branched, although other seven homogenous veins are not branched and seem to gradually approach each other distally; besides, A2 is unexpressed. However, the photograph by Hong [71] has not enough good quality and does not allow us to observe its correspondence with the drawing reconstruction. Because of the mentioned inconsistencies the genus Dictyocoleus is here considered as a member of the suborder Archostemata without a family attribution (familia incerta).

The genus Uralocoleus Zalessky, 1947 [64] (type species: Uralocoleus splendens Zalessky, 1947 [64]; by monotypy; Russia: Perm' Region (Barda Locality, Krutaya Katushka), Permian, Cisuralian, Artinskian/Kungurian (Kungurian), -279.5-272.5 Ma). The type specimen of this species is in a very bad condition to make a reliable comparison with the other tshekardocoleids. In the original description Zalessky [64] compared it with Permarrhaphus Martynov, 1931 [72] (now in Hypoperlida: family Ischnoneuridae Handlirsch 1906 (=Permarrhaphidae Martynov, 1931)). Nevertheless, Ponomarenko [26,69] emphasizided the clear "primary" veins and long anal vein along the sutural edge of the forewing of Uralocoleus splendens supporting its attribution to the Coleoptera. Later this last author described a congener of Uralocoleus, U. ultimus Ponomarenko, 2000 [73] (Russia: Arkhangel'sk Region (Soyana), Permian, Cisuralian/Guadalupian, Kungurian/Roadian (Cisuralian/Biarmian, Kungurian/Kazanian), -272.5-268.0 Ma), with "primary" veins scarcely traceable or partly absent, although, at the same time, with its general elytral cells very similar to those in tshekardocoleids. Ponomarenko ([73]: S314) wrote "The newly described elytron well agrees with the incomplete generic diagnosis, although some doubts in the generic placement still remain because of insufficiently known details of the type species. The enhanced diagnosis is not proposed here to avoid attributing the features of the Kazanian species to the whole genus." ... "The fore branch of $\mathrm{R}$ is distinct, the hind one is weak and quickly disappears among the polygonal cells. RS has a single branch starting at the basal third of the elytron and terminating at its apex, there are two rows of cells in each of the areas. The distinct common stem $\mathrm{M}+\mathrm{CuA}$ is absent, however, $\mathrm{M}$ is curved backwards near the basal quarter, then runs obliquely towards the apex, $\mathrm{CuA}$ originates among the polygonal cells at the level of $\mathrm{M}$ bent and has one row of cells in front of and behind, then $\mathrm{CuA}$ runs towards the apical third, curves distally along to the sutural margin, and has only one row of cells behind. CuP does not run to the sutural margin and disappears in polygonal cells little distal of the basal third of the elytron, there are four rows of cells in the area behind CuP at the base." ... "As only an isolated elytron is available, this species cannot be proved to be a beetle and not a cockroach." Thus, Uralocoleus splendens 
and "Uralocoleus" ultimus could be regarded as tshekardocoleid members and the latter species should be treated without generic attribution: genus incertus "ultimus" Ponomarenko, 2000 [73].

\section{On a Larva of the Family Tshekardocoleidae}

Comments. In addition to Cavalarva caudata Aristov et Rasnitsyn, 2015 [74] with unclear position, some holometabolan larvae were found among materials obtained from Tshekarda: Russia: Perm' Region, Suksun (Tshekarda, Sylva River), Permian, Cisuralian, Artinskian-Kungurian, -279.5-272.5 Ma. They represent two structural types [75]: campodeiform larvae with long walking legs and eruciform larvae with rather short legs or without observable legs. The latter type is rather similar to that in modern cupedines, and is due to be described and published (Prokin, Kirejtshuk and Makarov, in preparation).

Studied specimen. PIN 1700/4747 (Figure 3). Length 6.4, body width 1.7, head width $0.9 \mathrm{~mm}$. Body slightly separated on the thoracic and abdominal segments, slightly sclerotized, but head capsule and some part of tergites more or less sclerotized; abdominal segments with heavily sclerotized stigmae, ultimate abdominal segment with short median process acuminate at apex. The head capsula is somewhat reminiscent of that in the larva of the first instar of Priacma serrata LeConte, 1861 [76,77], however, the fossil larva is different from the mentioned modern one in the median apical process of the last abdominal segment (Figure 3C) looking like those in other modern cupedine larvae, while the larva of Priacma serrata has one pair of paramedian processes on the apex of the last abdominal segment.
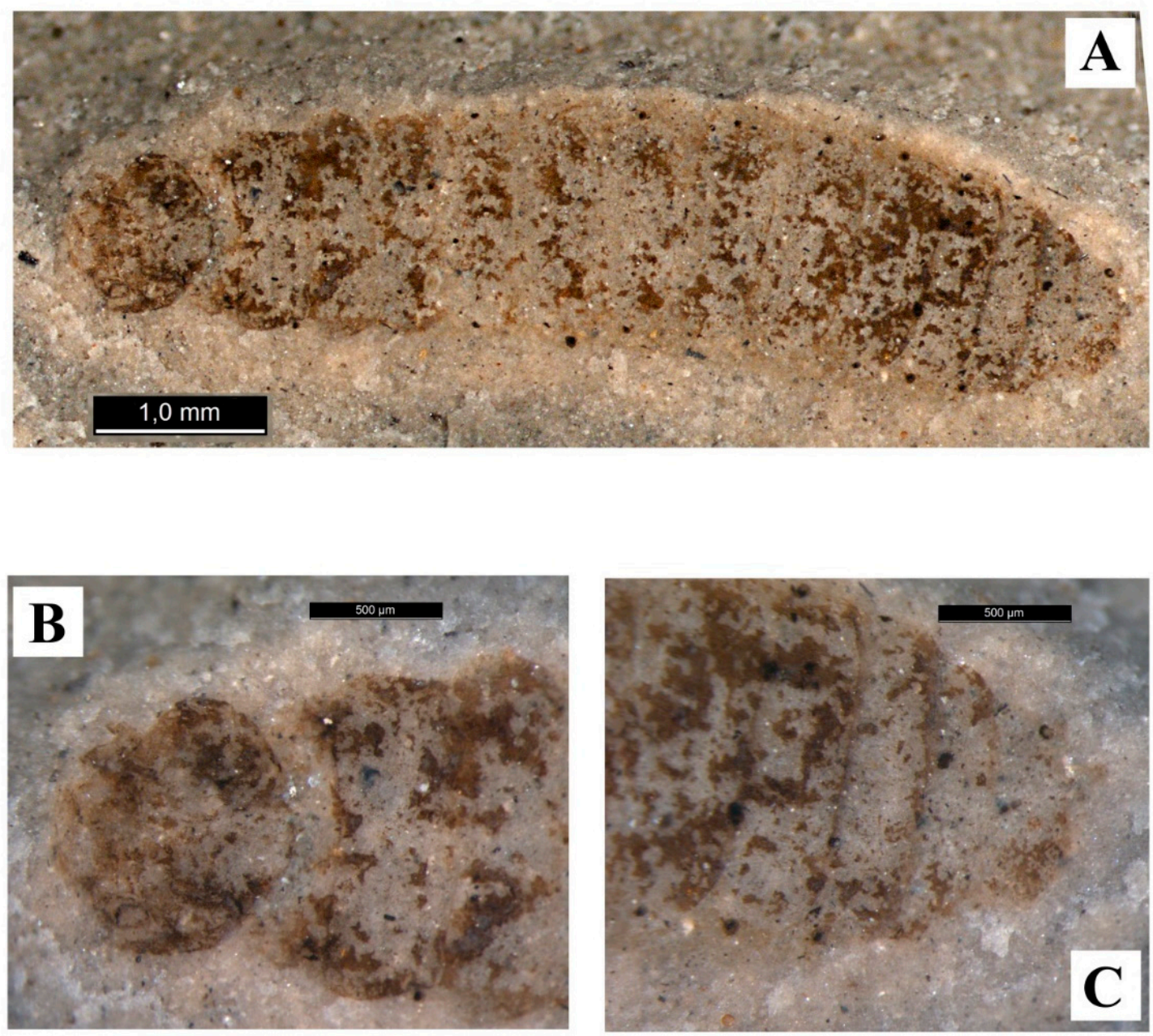

Figure 3. Tshekardocoleidae. Gen. et sp., larva, PIN 1700/4747, counterpart (Permian: Cisuralian, Artinskian-Kungurian; Perm' Region, Tshekarda): A-body wettened by alcohol, B-head, dry, C-abdominal apex, dry; scale for each picture; original. 
Family Labradorocoleidae Ponomarenko, 1969

Type genus: Labradorocoleus Ponomarenko, 1969 [78]

(one genus, one species)

Genus Labradorocoleus Ponomarenko 1969 [78]. Type species: Labradorocoleus carpenteri Ponomarenko 1969 [78], by monotypy. One species.

Canada: Newfoundland and Labrador (Redmond No. 1, Knob Lake District), Upper Cretaceous, Cenomanian, -99.7-94.3 Ma.

\section{Notes on the Family Labradorocoleidae}

Labradorocoleus carpenteri was originally described as a beetle related to Tshekardocoleidae [78]. However, it was later suggested to be a cockroach [73], probably taking into consideration that the anal vein of Labradorocoleus closest to the posterior edge follows it for some distance and becomes more widely separated than those in Tshekardocoleidae. Kirejtshuk et al. [32] analyzed all available characteristics in the forewings and showed that Labradorocoleus shares with Tshekardocoleidae and other Permian beetles most characteristics in venation, thus there is no doubt on its position among beetles.

Family Permocupedidae Martynov, 1932

Type genus: Permocupes Martynov, 1932 [79]

(= Kaltanocoleidae Rohdendorf, 1961, type genus Kaltanocoleus Rohdendorf, 1961 [2])

(24 genera, 54 species)

Comments. Ponomarenko in the 60s made a very important revision of the Palaeozoic "families" [26,69], etc. proposed for many descriptions and corrected in his later publications. These data were accumulated in Kirejtshuk and Ponomarenko [30]. The current studies of family and generic taxa of Archostemata make it possible to say that the differences between Permocupedidae sensu Ponomarenko, 1969 [26] and Taldycupedidae sensu Ponomarenko, 1969 [26] can be traced mostly in expression of the "primary" veins and other interspaces between longitudinal rows of cells ("intercalary veins") of the elytra and in the width of the prothoracic segment, although both structures demonstrate some level of uncertainty in different genera (Figure 2C,D). At the same time, other structures are known only in few specimens, which are very similar in both groups. Moreover, in some cases these differences are not clear and, therefore, these formal families are better temporally considered as not higher than subfamilies untill further facts on structures beyond elytra are obtained. Thus, in this paper these groups are preliminarily treated as subfamilies of one family but not as separate families, whose genera in some cases do not allow to clearly determine their attribution.

Subfamily Permocupedinae Martynov, 1932, sensu stricto

Type genus: Permocupes Martynov, 1932 [79]

(16 genera, 32 species)

Genus Afrocupes Geertsema et van den Heever, 1996 [80]. Type species: Afrocupes firmae Geertsema et van den Heever, 1996 [80], by monotypy. One species.

South Africa: Western Cape (Kenmoore Farm), Permian, Cisuralian, Sakmarian/Artinskian, -290.1-279.5 Ma.

Genus Archicupes Rohdendorf, 1961 [2]. Type species: Archicupes jacobsoni Rohdendorf, 1961 [2]; by original designation (= Palaeocupes Rohdendorf, 1961 [2], type species: Palaeocupes kaltanicus Rohdendorf, 1961 [2], by monotypy). Two species.

Russia, Kemerovo Region (Kaltan), Permian, Cisuralian/Guadalupian, Kungurian/Roadian (Cisuralian/Biarmian, Kungurian/Kazanian), -272.5-268.0 Ma. 
Notes. Archicupes jacobsoni and Palaeocupes kaltanicus were synonymized [26]. This automatically rendered synonyms the generic taxa Archicupes and Palaeocupes. On the other hand, according to Ponomarenko [26] another former congener of this genus, Archicupes reichardti, could be indeed a member of the genus Kaltanicupes rather than of Archicupes.

Genus Cytocupoides Ponomarenko, 1969 [26]. Type species: Cytocupoides longatus Ponomarenko, 1969 [26]; by monotypy. One species.

Russia: Kemerovo Region (Kaltan), Permian, Cisuralian/Guadalupian, Kungurian/Roadian (Cisuralian/Biarmian, Kungurian/Kazanian), -272.5-268.0 Ma.

Genus Cytocupes Rohdendorf, 1961 [2]. Type species: Cytocupes angustus Rohdendorf, 1961 [2]; by monotypy. One species.

Russia: Kemerovo Region (Kaltan), Permian, Cisuralian/Guadalupian, Kungurian/Roadian (Cisuralian/Biarmian, Kungurian/Kazanian), -272.5-268.0 Ma.

Genus Eocupes Rohdendorf, 1961 [2]. Type species: Eocupes lukjanovitshi Rohdendorf, 1961 [2]; by monotypy. Two species.

Another congener: Eocupes cellulosus Ponomarenko, 1969 [26].

Russia: Kemerovo Region (Kaltan), Permian, Cisuralian/Guadalupian, Kungurian/Roadian (Cisuralian/Biarmian, Kungurian/Kazanian), -272.5-268.0 Ma).

Genus Frankencupes Ponomarenko et Bashkuev 2018 [81]. Type species Frankencupes ultimus Ponomarenko et Bashkuev 2018 [81]; by monotypy. One species.

Germany: Gambach am Main (Lower Franconia), Middle Triassic, Olenekian/Anisian, $-247.2-242.0 \mathrm{Ma}$.

Genus Ichthyocupes Rohdendorf, 1961 [2]. Type species: Ichthyocupes tyzhnovi Rohdendorf 1961, by monotypy. Three species.

Other congeners: Ichthyocupes kuznetskiensis Ponomarenko, 1969 [26]; Ichthyocupes skoki (Rohdendorf, 1961) [2] [Permocupoides].

Russia: Kemerovo Region (Kaltan), Permian, Cisuralian/Guadalupian, Kungurian/Roadian (Cisuralian/Biarmian, Kungurian/Kazanian), -272.5-268.0 Ma; Kemerovo Region (Tykhta River, Sokolova, Kutsnetsk Basin), Permian, Lopingian, Wuchiapingian/Changhsingian (Tatarian, Severodvinian/Vyatkian), -259.0-252.3 Ma.

Genus Kaltanocoleus Rohdendorf, 1961 [2]. Type species: Kaltanocoleus pospelovi Rohdendorf, 1961 [2], by monotypy. One species.

Russia: Kemerovo Region (Kaltan), Permian, Cisuralian/Guadalupian, Kungurian/Roadian (Cisuralian/Biarmian, Kungurian/Kazanian), -272.5-268.0 Ma.

Genus Kaltanicupes Rohdendorf, 1961 [2]. Type species: Kaltanicupes richteri Rohdendorf, 1961 [2], by monotypy. Four species.

Other congeners: Kaltanicupes acutus Ponomarenko, 1963 [69], Kaltanicupes kargalensis Ponomarenko, 1963 [69], Kaltanicupes kitjakensis Ponomarenko, 1963 [69].

Russia: Kirov Region (Kityak), Permian, Cisuralian/Guadalupian, Kungurian/Roadian (Cisuralian/Biarmian, Kungurian/Kazanian), -272.5-268.0 Ma; Orenburg Region (Kargala), Permian, Guadalupian/Lopingian, Capitanian/Wuchiapingian (Tatarian, Sweverodvinian), -265.0-259.0 Ma; Kemerovo Region (Kaltan), Permian, Cisuralian/Guadalupian, Kungurian/Roadian (Cisuralian/Biarmian, Kungurian/Kazanian), -272.5-268.0 Ma.

Note. For Kaltanicupes ponomarenkoi Pinto, 1987 [67] the genus Pintolla gen.nov. is here proposed. One undescribed species of this genus was recorded from Indian Barakar Formation of the Lower Permian [82]. 
Genus Linicupes Ponomarenko, Yan et Huang, 2014 [83]. Type species: Linicupes yinpinensis Ponomarenko, Yan et Huang, 2014 [83], by monotypy. One species.

China: Anhui (Houdong, Yinping Mountain, SW Chaohu City), Permian, Guadalupian/Lopingian, Capitanian/Wuchiapingian (Tatarian, Severodvinian/Vyatkian), -265.0-259.0 Ma.

Genus Maricoleus Shcherbakov in Shcherbakov, Makarkin, Aristov \& Vasilenko, 2009 [84]. Type species: Maricoleus valentinae Shcherbakov in Shcherbakov, Makarkin, Aristov \& Vasilenko, 2009 [84], by monotypy. One species.

Russia, Primorsky Krai (Cape, Novosilsky, Russky Island), Lower Permian, Cisuralian, Artinskian/Kungurian (Cisuralian/Biarmian, Kungurian/Kazanian), -279.5-272.5 Ma.

Genus Permocupes Martynov, 1932 [79]. Type species: Permocupes semenovi Martynov, 1932 [79], by monotypy (= Permocupoides Martynov, 1932 [79], type species: Permocupoides distinctus Martynov, 1932 [79], by monotypy). Five species.

Congeners: Permocupes distinctus [79] [Permocupoides], Permocupes grandis Ponomarenko, 1963 [69], Permocupes latus Ponomarenko, 2013 [85], Permocupes semenovi [79], Permocupes sojanensis Ponomarenko, 1963 [69].

Russia: Arkhangel'sk Region (Letopala River and Soyana), Permian, Cisuralian/Guadalupian, Kungurian/Roadian (Cisuralian/Biarmian, Kungurian/Kazanian), -272.5-268.0 Ma; Udmurtia (Chepanikha, Rossokha River Valley), Permian, Guadalupian, Wordian (Biarmian, Urzhumian), -268.0-265.0 Ma: Tatarstan (Mendeleevsk District, Tikhie Gory), Permian, Cisuralian/Guadalupian, Kungurian/Roadian (Cisuralian/Biarmian, Kungurian/Kazanian), -272.5-268.0 Ma.

Genus Pintolla Kirejtshuk, gen. nov. Type species: Kaltanicupes ponomarenkoi Pinto, 1987 [69], by monotypy. One species.

Brazil: Rio Grande do Sul (Road Cut on Road BR 290 near Minas do Leao), Permian, Cisuralian, Artinskian/Kungurian (Cisuralian/Biarmian, Kungurian/Kazanian), -279.5-272.5 Ma.

Note. See below the descriptions of the new genus of the subfamily Permocupedinae.

Genus Protocupoides Rohdendorf, 1961 [2]. Type species: Protocupoides plavilstshikovi Rohdendorf, 1961 [2], by monotypy (= Tomiocupes Rohdendorf, 1961 [2]. Type species: Tomiocupes carinatus Rohdendorf, 1961 [2], by original designation; Tricupes Rohdendorf, 1961 [2]. Type species: Tricupes acer Rohdendorf, 1961 [2], by monotypy). Six species.

Congeners: Protocupoides acer (Rohdendorf, 1961) [2] [Tricupes], Protocupoides carinatus (Rohdendorf, 1961) [2] [Tomiocupes], Protocupoides elongatus Ponomarenko, 2013 [85], Protocupoides esini Ponomarenko 2013 [85], Protocupoides plavilstshikovi Rohdendorf, 1961 [2], Protocupoides sharovi Rohdendorf, 1961 [2]. Russia: Vologda Region (Isady locality, Mutovino), Permian, Lopingian, Wuchiapingian/Changhsingian (Tatarian, Severodvinskian/Vyatkian), -259.0-254.0 Ma; Udmurtia (Chepanikha, Rossokha River Valley), Permian, Guadalupian, Wordian (Biarmian, Urzhumian), -268.0-265.0 Ma; Kemerovo Region (Sokolova, Kutsnetsk Basin), Permian, Lopingian, Wuchiapingian/Changhsingian (Tatarian, Severodvinian/Vyatkian), -259.0-252.3 Ma; Kemerovo Region (Kaltan), Permian, Cisuralian/Guadalupian, Kungurian/Roadian (Cisuralian/Biarmian, Kungurian/Kazanian), -272.5-268.0 Ma.

Notes. "Permocupes" rohdendorfi Pinto, 1987 [67] from Brazil (Rio Grande do Sul (Road Cut on Road BR 290 near Minas do Leao), Permian, Kungurian, -279.5-272.5 Ma) can scarcely be identified as this genus because its holotype is represented by the only incomplete distal part of the elytron.

Genus Tatarocupes Ponomarenko, 2004 [86]. Type species: Tatarocupes granulatus Ponomarenko, 2004 [86] (Figure 2D,E), by monotypy. One species.

Russia: Orenburg Region (Novo-Aleksandrovka), Permian, Guadalupian/Lopingian, Capitanian/Wuchiapingian (Tatarian, Severodvinian), -265.0-259.0 Ma. 
Genus Uralocupes Ponomarenko, 1969 [26]. Type species: Kaltanicupes major Ponomarenko, 1963 [69], by monotypy. One species.

Russia: Kirov Region (Kityak), Permian, Cisuralian/Guadalupian, Kungurian/Roadian (Cisuralian/Biarmian, Kungurian/Kazanian), -272.5-268.0 Ma.

\section{New Genus of the Subfamily Permocupedinae}

Genus Pintolla Kirejtshuk, gen. nov.

urn:lsid:zoobank.org:act:D08C5063-59EF-4110-B903-F89CF69B1109

Type species: Kaltanicupes ponomarenkoi Pinto, 1987 [67]; fossil, Brazil, Rio Grande do Sul (Road Cut on Road BR 290 near Minas do Leao) Permian, Cisuralian, Artinskian/Kungurian (Cisuralian/Biarmian, Kungurian/Kazanian), -279.5-272.5 Ma.

Composition. Type species only (Pintolla ponomarenkoi comb. nov.).

Diagnosis. This new genus is similar to Kaltanicupes, but differs from it in the markedly more weakly curved veins and longitudinal rows of cells on its elytra (veins in the photographs of the holotype of Pintolla ponomarenkoi comb. nov. are scarcely observable, although in one of the photographs the traced veins correspond to those in the drawing-reconstruction: [67]: 6, Figure 1; Pl. 1, Figure 1a,b). In contrast to many permocupedines (including Kaltanicupes), Pintolla ponomarenkoi comb. nov. has not any clear triangle of cells between $\mathrm{Cu}$ and $\mathrm{A} 1$ at the elytral base. Besides, the prescutellar cells of its elytra demonstrate more than one row of cells and there are two rows of cells between R and M, M and $\mathrm{Cu}$, and also $\mathrm{Cu}$ and $\mathrm{A} 1$.

Etymology. The name of the new genus is formed from the name of the descriptor of the type species (Irajá Damiani Pinto) and suffix "lla". Gender feminine.

\section{Notes on the Subfamily Permocupedinae}

The taxon Afrocupes was synonymized with Permocupes on-line by Ponomarenko and Kirejtshuk [29] because its elytral venation is very similar to that in Martynov's Permocupes and "Permocupoides", although the cells in the distal part of the elytron seem to become smaller more gradually.

The genus Archicupes was initially proposed for two species (type species, A. jacobsoni, and A. reichardti), whose holotypes were collected in the same locality (Kaltan) in the Kuznetzk Basin. The holotype of the first species is represented only by the left elytron, while that of the second one has the body and some parts of the appendages. Ponomarenko [26] synonymized Archicupes jacobsoni with Palaeocupes kaltanicus, but the second initial congener of Archicupes (A. reichardti) was excluded from this genus by this author, because A1 (A2 after Ponomarenko [26]) of the second species is markedly longer than in the type species. Nevertheless, elytra of both species of Archicupes included by Rohdendorf show considerable similarity, except for the length of the mentioned anal vein. Ponomarenko [26] wrote that Archicupes reichardti could belong to Kaltanicupes and Eocupes without providing any additional argument. It is a good idea to revise these three genera or perhaps all permocupedines to determine the relation between the genera currently included in this subfamily.

According to Ponomarenko [26] the type specimen of Kaltanocoleus pospelovi has the subcostal area and base of elytron missing, but its anal field is similar to that in species of Kaltanicupes and Eocupes. Indeed the holotype of this species at the time of the Rohdendorfian description had a clear venation and cells that were drawn and pictured ([2]: Text-Figure 319 and Pl. XXIX, Figure 190) demonstrating the rather distinct $R$ branch. This genus and species can be diagnosed with the Rohdendorf's [2] keys.

The holotype elytron of "Taldycupes" chachlovi Rohdendorf, 1961 [2] (Russia: Kemerovo Region (Suriekova), Permian, Cisuralian/Guadalupian, Kungurian/Roadian (Cisuralian/Biarmian, Kungurian/Kazanian), -272.5-268.0 Ma) is longer, less convex and finely microtuberculate in comparson with other species of Taldycupes. It has eight rows of large cells, instead of ten as in other species of this genus. Thus, the later species seems to belong to another genus. However the holotype of this species is represented only by the apical part of the elytron bearing the same characteristics as Taldycupedidae 
and Permocupedidae. Ponomarenko [26] put this species in the latter family because of the "primary" veins of its elytra are different from other interspaces between longitudinal rows of cells.

The genus Protocupes Rohdendorf, 1961 [2] is represented by two species, type species: Protocupes martynovi Rohdendorf, 1961 [2] and another congener: P. ogloblini Rohdendorf, 1961 [2]. Both species originated from the same locality (Kaltan) in the Kuznetzk Basin (Russia: Kemerovo Region (Kaltan), Permian, Cisuralian/Guadalupian, Kungurian/Roadian (Cisuralian/Biarmian, Kungurian/Kazanian), -272.5-268.0 Ma) and illustrated only by the drawing-reconstructions. The holotype of the former species is represented by a considerable distal part of the elytron ([2]: figures 330,331), while the holotype of the latter species shows only a small part of the elytral base ([2]: figure 332). Ponomarenko [26] regarded these species separately as genera incertae sedis. The last author published another drawing-reconstruction of the type species of this "genus" different from that published by Rohdendorf, but again without providing this reconstruction with a photograph. Thus, it is impossible to clarify which of these reconstructions is more correct or more adequate for the remainder of the specimen. As a result, the genus Protocupes should be considered as a taxon incertae sedis among members of Permocupedidae and with unclear composition (one or two species).

Stegocupes efremovi Rohdendorf 1961 [2] was described together with the type species of this genus (S. fedotovi Rohdendorf 1961 [2]). Both species originated from the same locality (Kaltan) in the Kuznetzk Basin and have some similarity in the body shape, microtuberculate integument of the elytra and thickened apical 5-6 antennomeres. Ponomarenko [26] redescrided Stegocupes efremovi taking into consideration its pronotum as different from that in other taldycupedids but the dorsal integument of the elytra is not clear in its holotype; as a result, he transferred this species to the permocupedids (i.e., permocupedines), although the later description does not include the peculiar antennal structure, microtuberculate integument of the elytra and uniform elytral venation (first descriptor considered that in Stegocupes a trend to reduction of venation and cells together with sclerotization of the elytral integument is to be observed [2]). Both descriptions of Stegocupes efremovi [2,26] do not contain the photographs and, therefore, it is difficult to choose the more correct one without re-examination of the holotype. This species has been preliminarily re-transferred back to the taldycupedine genus Tecticupes (which is provisionally regarded as the senior synonym of Stegocupes).

Subfamily Taldycupedinae Rohdendorf, 1961, stat. nov.

Type genus: Taldycupes Rohdendorf, 1961 [2]

(eight genera, 22 species)

Genus Afrotaldycupes Kirejtshuk, gen. nov. Type species: Taldycupes africanus Ponomarenko in Ponomarenko \& Mostovski, 2005 [87], here designated. Two species.

Congeners: Taldycupes africanus, comb. nov., Afrotaldycupes lidgettoniensis (Ponomarenko in Ponomarenko \& Mostovski, 2005) [Taldycupes], comb. nov. [87].

South Africa: Kwazulu-Natal; Permian, Lopingian, Wuchiapingian/Changhsingian (Tatarian, Vyatkian), -254.0-252.3 Ma.

Genus Lobanovia Kirejtshuk, gen. nov. Type species: Simmondsia permiana Ponomarenko, 2013 [85], by monotypy. One species.

Russia; Vologda Region (Isady), Permian, Lopingian, Wuchiapingian/Changhsingian (Tatarian, Severodvinian), -259.0-254.0 Ma.

Genus Mesothoris Dunstan, 1923 [88]. Type species Mesothoris clathrata Tillyard, 1916 [89], by monotypy. Three species.

Other congeners: Mesothoris grandis Dunstan, 1923 [88] (?) Mesothoris punctomarginum (Dunstan, 1923) [88] [Elaterium].

Australia: Queensland (Denmark Hill); Upper Triassic, Norian, -221.5-205.6 Ma. 
Notes. Rohdendorf [2] supposed that the genera Mesothoris and Simmondsia could be close to the "Taldycupedidae". Kirejtshuk et al. [33] admitted that the type species of Mesothoris (M. clathrata) and some other species belong to the Archostemata with 10 long longitudinal rows of subquadrangular cells and unclear difference between veins and other interspaces between longitudinal rows of cells (M. grandis and M. westraliensis), although Mesothoris tenuiclathrata Dunstan, 1923 [88] and M. quadripartita Dunstan, 1923 [88] have a much greater number of long longitudinal rows and could be transferred to the genus Mesolobites Carpenter, 1986 [90] (= Lobites Dunstan, 1923 [88], non Mojsisovics, 1873 [91]) of the family Schizocoleidae Rohdendorf, 1961 [29,33]. One species was described after study on a separate elytron as a member of the genus Elaterium Westwood, 1854 [92] (E. punctomarginum Dunstan, 1923 [88]) with 11 long longitudinal rows of cells, including one row placed along the explanate stripe of the elytral side.

Genus Simmondsia Dunstan, 1923 [88]. Type species: Simmondsia subpiriformis Dunstan 1923 [88], by original designation. Two species.

Another congener: Simmondsia cylindrica Dunstan, 1923 [88].

Australia: Queensland (Denmark Hill, Insect Bed), Upper Triassic, Norian, -221.5-205.6 Ma.

Notes. The genus Simmondsia was described from Australia and is known by two species from the same locality (Denmark Hills in Queensland) having eight veins and nine long longitudinal rows of cells. Ponomarenko [26] put in this genus Tychticupes ragozini, because according to him, the elytron of the latter species has two rows of cells in the cubital field. However, in contrast to the Australian species of Simmondsia, Tychticupes ragozini has a short prescutellar row of cells restricted by A2, while the Australian species demonstrate the rather long row of adsutural cells separating A2 nearly upto the elytral apex. Thus, if Tychticupes ragozini can be considered as a group isolated from other members of Tychticupes, it is necessary to establish a new separate genus for it after its detailed redescription. Later Ponomarenko [85] added to Simmondsia another Permian species ("Simmondsia" permiana) from the Vologda Region (European part of Russia) with ten long longitudinal rows of cells. However such a joining of species is scarcely reasonable and, therefore, for the latter is here proposed a new "formal" genus (see above the genus Lobanovia gen. nov. and the below description of it).

Genus Taldycupes Rohdendorf, 1961 [2]. Type species: T. khalfini Rohdendorf, 1961 [2], by original designation (=Taldycupidium Rohdendorf, 1961 [2]. Type species: Taldycupidium bergi Rohdendorf, 1961 [2], by monotypy; Cryptocupes Rohdendorf, 1961 [2]. Type species: Cryptocupes rjabinini Rohdendorf 1961 [2], by monotypy). Seven species.

Congeners: Taldycupes bergi (Rohdendorf, 1961) [2] [Taldycupidium] (=rjabinini Rohdendorf 1961 [2] [Cryptocupes]), Taldycupes cellulosus Ponomarenko 2013 [86], Taldycupes khalfini Rohdendorf, 1961 [2], Taldycupes moltshanovi Rohdendorf, 1961 [2], Taldycupes pingi Ponomarenko, Yan et Huang, 2014 [83], Taldycupes reticulatus Ponomarenko, 1969 [26], Taldycupes rosanovi Ponomarenko, 2006 [93], Taldycupes vasjuchitshevi (Rohdendorf, 1961) [2] [Tychticupes].

Russia: Vologda Region; Permian, Lopingian, Wuchiapingian/Changhsingian (Tatarian, Severodvinskian/Vyatkian), -259.0-254.0 Ma; Kemerovo Region (Sokolova) Permian, Lopingian, Wuchiapingian/Changhsingian (Tatarian, Severodvinian/Vyatkian), -259.0-252.3 Ma; Krasnoyarsk Krai (Ilimpeya locality), Permian, Lopingian, Changhsingian (Tatarian, Vyatkian), -254.0-251.3 Ma.

Kazakhstan: East-Kazakhstan Region (Zaisan, Karaungir), Permian, Lopingian, Changhsingian (Tatarian, Vyatkian), -254.0-252.3 Ma.

China: Anhui Province (Houdong, Yinping Mountain, SW Chaohu City), Permian, Guadalupian, Capitanian/Wuchiapingian (Tatarian, Serverodvinian/Vyatkian), -265.0-259.0 Ma.

Genus Tecticupes Rohdendorf, 1961 [2]. Type species: Tecticupes heckeri Rohdendorf, 1961 (?=efremovi Rohdendorf 1961 [2] [Stegocupes]) (?=Stegocupes Rohdendorf 1961 [2]. Type species Stegocupes fedotovi Rohdendorf 1961 [2]). Three species. 
Other congeners: Tecticupes indistinctus Rohdendorf, 1961 [2] (?= tchichatchevi Rohdendorf, 1961 [2], see [26]: lapsus calami: "tshichatsheffi"), Tecticupes martynovi Ponomarenko, 2013 [82].

Russia: Kemerovo Region (Seriekovo), Permian, Cisuralian/Guadalupian, Kungarian/Roadian (Cisuralian/Biarmian, Kungurian/Kazanian), -272.5-268.0 Ma; Orenburg Region (Kargala), Permian, Guadalupian/Lopingian, Capitanian/Wuchiapingian (Tatarian, Severodvinian), -265.0-259.0 Ma.

Notes. In addition to the uncertainty in the interpretation of Stegocupes efremovi (see above) this generic taxon also has a problem in its interpretation. Ponomarenko [26] redescribed Stegocupes efremovi in the chapter devoted to the family Permocupedidae (i.e., Permocupedinae), but in the chapter devoted to Taldycupedidae (i.e., Taldycupedinae) he treated the name Stegocupes as a junior synonym of Tecticupes with the consideration of Stegocupes efremovi but not the type species Stegocupes fedotovi and with the mention of the positive and negative imprints of the holotype of Stegocupes efremovi. Rohdendorf [2] did not indicate two imprints for both Stegocupes fedotovi and S. efremovi. As the Ponomarenko and Rohdendorf descriptions and drawings of Stegocupes efremovi share many identical features, the first mention of this species ([26]: 69 and 70) should be considered as corresponding to its holotype. As to the second mention of this name in the chapter on "taldycupedids" ([26]: 223), it concerns another species (could be another congeners, erroneously named as Stegocupes efremovi instead of E. fedotovi). As a result, it is impossible to undoubtedly interpret the Ponomarenko notes on the synonymy of the generic names Stegocupes and Tecticupes (see also the above notes on permocupedines) without re-examination of the holotypes of both members of the genus Stegocupes. The necessity of such revision of the above-mentioned specimens is even more urgent because Rohdendorf published some additional comments [94], according to which the genus Stegocupes is characterized by six ventrites (but not five as should be the case in cupedoids).

Genus Tychticupes Rohdendorf, 1961 [2]. Type species: Tychticupes radtshenkoi Rohdendorf, 1961 [2], by original designation. Three species.

Other congeners: Tychticupes beljanini (Rohdendorf, 1961) [2] [Taldycupes], Tychticupes ragozini Rohdendorf, 1961 [2] (lapsus calami: ragosini), (?) Tychticupes tchihatcheffi Rohdendorf 1961 [2].

Russia: Kemerovo Region (Tykhta River, Sokolova), Permian, Lopingian, Wuchiapingian/Changhsingian (Tatarian, Severodvinian/Vyatkian), -259.0-252.3 Ma; Kemerovo Region (Suriekova), Permian, Cisuralian/Guadalupian, Kungurian/Roadian (Cisuralian/Biarmian, Kungurian/Kazanian), -272.5-268.0 Ma.

Note. See the above Notes to Simmondsia.

Genus Tychticupoides Rohdendorf, 1961 [2]. Type species: Tychticupoides grjasevi Rohdendorf, 1961 [2], by monotypy. One species.

Russia: Kemerovo Region (Sokolova), Permian, Lopingian, Wuchiapingian/Changhsingian (Tatarian, Severodvinian/Vyatkian), -259.0-252.3 Ma.

\section{New Taxa of Taldycupedinae}

\section{Genus Afrotaldycupes Kirejtshuk, gen. nov.}

urn:lsid:zoobank.org:act:C3D846DC-CD0E-4B2A-9B6B-3E99B4A77720

Type species: Taldycupes africanus Ponomarenko in Ponomarenko \& Mostovski, 2005 [87]; fossil, Permian, South Africa (Kwazulu-Natal).

Composition. Type species (Afrotaldycupes africanus comb. nov.) and A. lidgettoniensis (Ponomarenko in Ponomarenko \& Mostovski, 2005 [87]), comb. nov. [Taldycupes].

Diagnosis. This new genus is characterized by 10 longitudinal irregular rows of oval cells. The elytron of Afrotaldycupes africanus comb. nov. is very similar to Taldycupes and differs from it mostly in the type of cells arranged in irregular longitudinal rows of oval cells of different in size and probably one short prescutellar row of cells. Besides, three veins ending on the elytral lateral edge. 
Notes. Afrotaldycupes gen. nov. is proposed after the current observation of characteristics of the elytral structure and, therefore, it should be regarded as a "formal" or "collective" genus ("morphogenus") as in many cases of permocupedids. In contrast to Afrotaldycupes gen. nov., the Eurasian members of Taldycupes demonstrate elytra with regular longitudinal rows of subquadrate to subpolygonal cells, and only the elytron of T. cellulosus shows subquadrate to a little suboval cells disposed in the regular and somewhat curved rows and veins ending to the elytral apex.

Etymology. The name of this new genus is formed from the name of the continent (Africa) and generic name Taldycupes. Gender masculine.

Genus Lobanovia Kirejtshuk, gen. nov.

urn:lsid:zoobank.org:act:2946FA2C-6E32-4ABB-9B1C-570752E5D547

Type species. Simmondsia permiana Ponomarenko, 2013 [85]; fossil, Permian, Lopingian; Russia (Vologda Region).

Composition. Type species only (Lobanovia permiana comb. nov.).

Diagnosis (after analysis of holotype of Lobanovia permiana comb. nov.). This new genus is characterized by 10 longitudinal regular rows of suboval to subquadrate cells ending on the lateral elytral edge. The elytron of Lobanovia permiana comb. nov. is very similar to those in the Australian species of Simmondsia subpiriformis and S. cylindrica, but differs from them in the greater number of longitudinal rows of suboval to subquadrate cells (species of Simmondsia have nine longitudinal rows of subquadrate to very transverse cells). Despite a similarity in the general outline of the elytra of the species of Simmondsia (particularly elytron of Simmondsia subpiriformis), Lobanovia permiana comb. nov. has more veins and longitudinal rows of cells which end on the elytral lateral edge (while the veins of the species of Simmondsia end on the elytral apex).

Etymology. The name of this new genus is dedicated to Andrey L'vovich Lobanov, who for years made possible the successful development of the web-side "Beetles (Coleoptera) and coleopterists" [https: //www.zin.ru/Animalia/Coleoptera/rus/index.html]. Gender feminine.

\section{Notes on the Family Taldycupedinae}

The genus Alveolacupes Lin, 1983 [95] (type species: Alveolacupes primus Lin, 1983 [95], by original designation) was proposed after the description of the left elytron of the types species and the right elytron of Alveolacupes secundus Lin, 1983 [95] (lapsus calami "secundes") (both from China: Hunan Province; Upper Triassic, Norian/Rhaetian, -205.6-201.6 Ma), however Ponomarenko et al. [96] considered them as Permosynidae, as these elytra are not cellular but "striato-punctate".

The genus Clathropenna Fujiyama 1973 [97] (type species: Clathropenna rugosa Fujiyama 1973 [97], by monotypy; Japan: Omine; Upper Triassic, Ladinian/Carnian, -235.0-221.5 Ma) was originally described as a member of Taldycupedidae. However Ponomarenko et al. [96] indicated that this generic taxon is based on a part of the elytron with destroyed upper surface and, therefore, it cannot be identified as a member of any family, although it differs from other early Mesozoic beetles in the peculiar pattern of the elytral punctation. The genus Penecupes Ren, 1995 [98] with the type species: Penecupes rapax Ren, 1995 [98] (China: Beijing Shi (Chongqing Reservoir), Lower Cretaceous, Late/Upper Aptian, -122.5-112.6 Ma) was transferred to the subfamily Protorabinae Ponomarenko, 1977 [30].

\section{Family Cupedidae Laporte, 1836}

Type genus: Cupes Fabricius, 1801 [99]

(Three subfamilies, 47 genera, 249 species)

Comments. This family has a very distinct structural base in many body sclerites and appendages, including the elytral venation, which is maintained or can be traced in different phyletic branches, including two of them reaching the modern epoch (Figures 4-24). This feature seemed to combine 
with parallel structural transformations, on one hand, and very frequent disappearance in specialized groups existed in various geological periods. As a result, the groups slightly structurally modified are present in the Recent fauna, while the more advanced apotypic representatives left only in the fossil record. Ponomarenko [26] elaborated a key to the cupedid subfamilies, which was later emended by Kirejtshuk et al. [33]. Nevertheless the characteristics in them should still be regarded as tentative because their diagnostic value is not enough reliable. The separated or contiguous procoxae represent the alone feature which can be used for discrimination of cupedines and ommatines. If these characteristics are not observable an assignement of fossils to any supraspecific taxon becomes more or less depending on available additional characteristics associated with certain groups but not diagnostic or restrictedly diagnostic ones for these groups.

In addition, the genera and species included in this review, the descriptions of two new ommatine genera with four species recently described are put in the Appendix A (see below).

\section{Subfamily Ommatinae Sharp et Muir, 1912}

Type genus: Omma Newman, 1839 [100] (23 genera, 165 species)

(= Brochocoleinae Hong, 1982 [Brochocoleidae], type genus: Brochocoleus Hong, 1982 [71]; Clessidrommatini Jarzembowski, Wang et Zheng, 2017, type genus: Clessidromma Jarzembowski, Wang et Zheng, 2017 [101]; Lithocupedini Ponomarenko, 1969, type genus: Lithocupes Ponomarenko, 1966 [102]; Notocupedini Ponomarenko, 1966, type genus: Notocupes Ponomarenko, 1964 [103]; Pronotocupedini Tan, Wang, Ren et Yang, 2012, type genus not proposed; Tetraphalerini Crowson, 1962, type genus: Tetraphalerus Waterhouse, 1901 [104])

Comments. This subfamily is distinct among fossil cupedids mostly in the contiguous procoxae. The key to tribes of this subfamily for fossil beetles was elaborated by Ponomarenko [26], however later the description of many new generic taxa of Ommatinae makes it necessary to revise many taxa with a wide comparison of all groups of the subfamily. Perhaps, the ommatine genera without prothoracic lateral carinae (Figure 4C-F, Figures 5-8, 13 and 14) are more closely related and should be united in one tribe (Ommatini sensu stricto). On the other hand, it is necessary to take into consideration that some structures are characterized by a strong trend to similar modifications in a definite group (i.e., elytral cells and punctation) or parallel transformations in different and not closely related groups (i.e., some structural changes in elytral venation).

Genus Allophalerus Kirejtshuk, gen. nov. (Figure 4A,B). Type species: Tetraphalerus aphaleratus Ponomarenko, 1969 [26], here designated. Nine species.

Other congeners: Allophalerus antiquus (Ponomarenko, 1964) [103], comb. nov. [Tetraphalerus], Allophalerus bontsaganensis (Ponomarenko, 1997) [105], comb. nov. [Tetraphalerus], (?) Allophalerus incertus (Ponomarenko, 1969) [26], comb. nov. [Tetraphalerus], Allophalerus latus (Tan, Ren et Shih, 2007) [106], comb. nov. [Tetraphalerus] (Figure 4A-B), (?) Allophalerus maximus (Ponomarenko, 1968) [107], comb. nov. [Tetraphalerus], Allophalerus okhotensis (Ponomarenko, 1993) [108], comb. nov. [Tetraphalerus], Allophalerus tenuipes (Ponomarenko, 1964) [103], comb. nov. [Tetraphalerus], Allophalerus verrucosus (Ponomarenko, 1966) [109], comb. nov. [Tetraphalerus].

Russia: Khabarovsk Krai (Khetana River), Upper Cretaceous, Cenomanian/Turonian -94.3-89.3 Ma; Buryatia (Transbaikalia, Baissa), Lower Cretaceous, Aptian, -125.5-112.6 Ma.

Kazakhstan: Chimkent Region (Karatau-Karabastau, Karatau-Galkino, Mikhailovka), Middle/Upper Jurassic, Callovian/Oxfordian, -164.7-155.7 Ma.

Kyrgyzstan: Tonskiy (Ak-Bulak-Say, Sogyuta, Issyk-Kul), Upper Triassic/Lower Jurassic, Rhaetanian/Hettangian, -201.6-189.6 Ma; Osh Region (Kyzyl-Kiya), Lower Jurassic, Pliensbachian (Pliensbachian/Toarcian), -189.6-183.0 Ma.

Mongolia: Bayan-Khongor Aimag (Bon Tsagaan), Lower Cretaceous, Barremian, -130.0-125.5 Ma; Bayan-Khongor Aimag (Kholbotu-Gol), Lower Cretaceous, Hauterivian/Barremian, -136.4-125.5 Ma. 
China: Liaoning Province (Huangbanjigou, Chaomidian Village), Lower Cretaceous, Lower Aptian, -125.5-122.5 Ma.

Notes. Allophalerus incertus comb. nov. is preliminarily considered as a member of this genus (formerly usually named as Tetraphalerus), although the explanate elytral sides of its holotype in the photograph ([26]: P1. VIII, 3) seem to have comparatively large cells like those in species of Pareuryomma. The photographs of the holotype of Allophalerus maximus comb. nov. ([107]: P1. XIII, 6 and 7) show its explanate elytral sides that are not wide and with unclear sculpture. See below the Descriptions of new taxa of the subfamily Ommatinae.
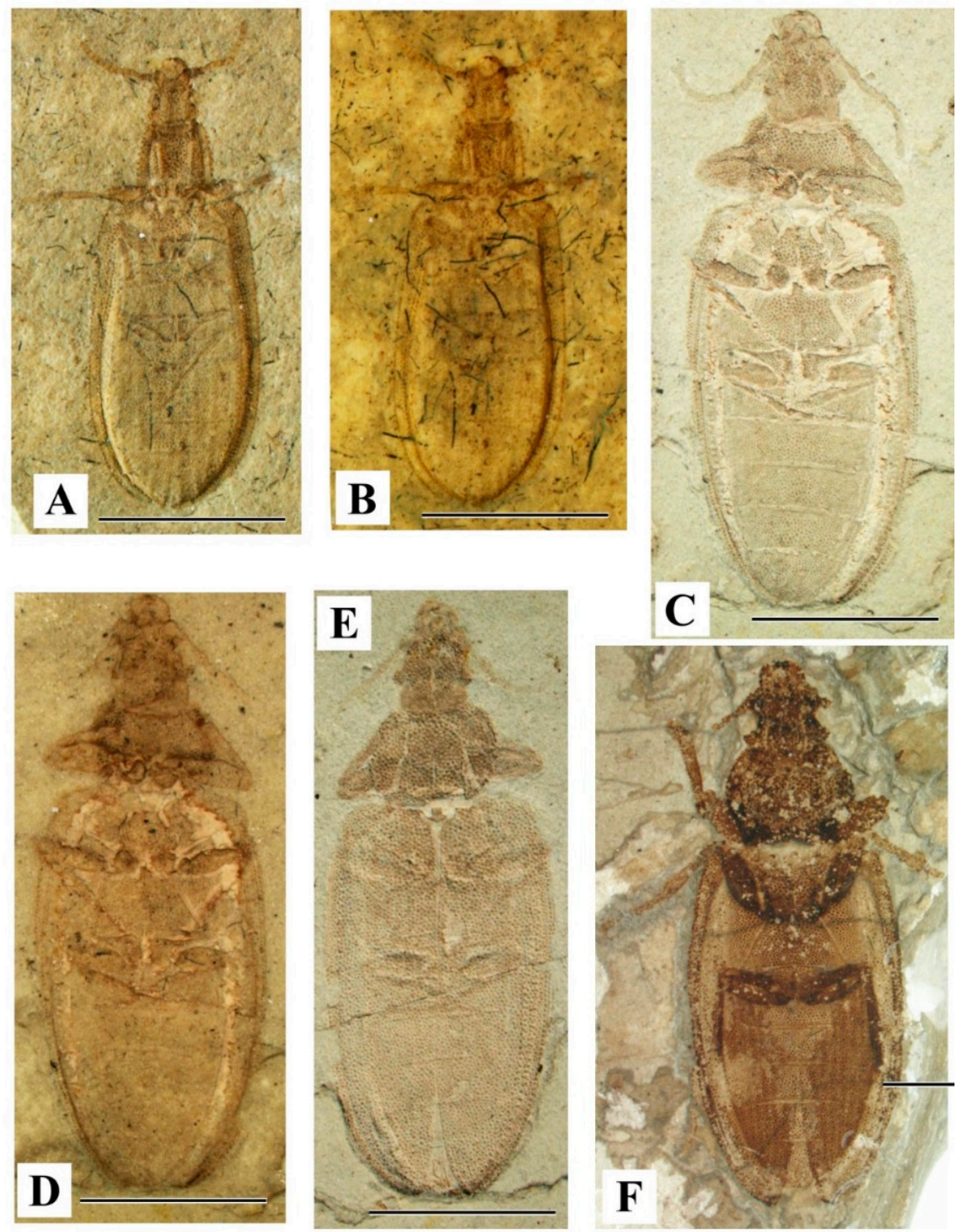

Figure 4. Ommatinae (Cupedidae): A-B-Allophalerus latus comb. nov. [Tetraphalerus], holotype CNU-C-LB2006005-1 (Lower Cretaceous, Lower Aptian Liaoning, Chaomidian); A-dry and B-wettened by alcohol: length of print $9.0 \mathrm{~mm}$, scale bar $=3.7 \mathrm{~mm}$; original. C-E-Cionocoleus cervicalis, holotype, part CNU-C-LB2006007-1 and counterpart CNU-C-LB2006007-2 (Lower Cretaceous, Lower Aptian Liaoning, Chaomidian): C-part, dry, D -part, wettened by alcohol, E-counterpart, dry; length of print $24.0 \mathrm{~mm}$, scale bar $=7.0 \mathrm{~mm}$; original. F-Cionocoleus planiusculus, holotype CNU-C-LB2006008 (Lower Cretaceous, Lower Aptian Liaoning, Chaomidian): part, dry; length of print $21.5 \mathrm{~mm}$, scale bar $=7.2 \mathrm{~mm}$; original. 
Genus Blapsium Westwood, 1854 [92]. Type species Blapsium egertoni Westwood, 1854 [92], by monotypy. One species.

United Kingdom: England (Oxfordshire, Stonesfield); Middle Jurassic, Bathonian, $-167.7-164.7$ Ma.

Notes. Ponomarenko ([110]: 89) after re-examination of the holotype of Blapsium egertoni represented by only the underside of metathorax, metacoxae, abdomen and elytral epipleura came to the conclusion that it belongs to the archostematan tribe Notocupedini because of the characteristic metepisterna, metacoxae and short overlapping abdominal ventrites. He also considered that this species was apterous because of its rather short metathorax.

Genus Brochocoleus Hong, 1982 [71]. Type genus: Brochocoleus punctatus, Hong 1982 [71], by monotypy. Eight species.

Other congeners: (?) Brochocoleus alatus Ponomarenko, 1994 [111], Brochocoleus cossiphus Ponomarenko, 1994 [111], Brochocoleus maculatus (Whalley, 1985) [112] [Liassocupes], Brochocoleus keenani Jarzembowski, Yan, Wang et Zhang, 2013 [113], Brochocoleus maximus Jarzembowski, Yan, Wang et Zhang, 2013 [113], (?) Brochocoleus planus Ponomarenko 1994 [111], Brochocoleus rostratus Ponomarenko, 1999 [114], Brochocoleus tobini Jarzembowski, Yan, Wang et Zhang, 2013 [113].

United Kingdom: England (Charmouth), Lower Jurassic, Upper Sinemurian, -196.5-189.6 Ma; England (Smokejacks Brickworks), Lower Cretaceous, Lower Barremian, -130.0-125.5 Ma; England (Durlston Bay), Lower Cretaceous, Late/Upper Berriasian, -145.5-140.2 Ma; England (Burgess Hill), Lower Cretaceous, Late/Upper Hauterivian, -136.4-130.0 M).

Kazakhstan: Kzyl-Ordinskaya Region (Kzyl-Zhar or Kzyl-Dzhar), Upper Cretaceous, Turonian, -94.3-89.3 Ma.

Mongolia: Bayan-Khongor Aimag (Bon Tsagaan), Lower Cretaceous, Barremian, -130.0-125.5 Ma; Bayan-Khongor Aimag (Khurilt and Bon Tsagaan), LowerCretaceous, Aptian, -125.45-112.6 Ma; Gobi-Altay Aimag (Erdeni-Ula), Lower Cretaceous, Hauterivian/Barremian, -136.4-125.5 Ma.

China: Gansu Province (Chijinqiao), Lower Cretaceous, Aptian, -125.5-112.6 Ma.

Notes. The genus Brochocoleus was proposed after the study of an isolated elytron with longitudinal rows of large cells and very wide explanate side having the shoulder corner projecting anteriorly and bearing longitudinal rows of especially large cells. The latter cells were drawn by the descriptor with very clear outlines ([71]: 104, Figures 73 and 74), while they are not quite clear in photographs of Hong ([71]: Pl. 1-4). Taking into consideration other species here included in this genus, it can be defined that Brochocoleus is characterized by the rather wide and comparatively robust body with the elytra having Sc curved along the elytral lateral edge so that the other veins without fusion terminate on it apically, and by the longitudinal rows of more or less clearly expressed cells and extremely widely explanate elytral sides with very large cells arranged in 2-3 rows of large cells (typically two long rows and at base one short row of cells between them). The head in species of this genus is long and with long temples. Their prothorax is narrow, arcuate at sides and with more or less expressed lateral carinae. The abdominal ventrites of this group are co-planar (abutting).

Another group with somewhat similar elytral venation, but with a slenderer body, prothorax distinctly carinate and explanate at sides, elytra having fused $\mathrm{A} 1$ with $\mathrm{Cu}$, and $\mathrm{M}$ with R just at the elytral apex, and also double rows of cells, irregular rows of microtubercles or with diffuse microtubercles (or punctures) along the not very widely explanate elytral sides and shoulder corner not projecting anteriorly has a sufficient morphological hiatus with Brochocoleus in order to regard it as a separate taxon. Ren [98] proposed the generic taxon, Diluticupes Ren, 1995 [98], for one species of this group (Diluticupes impressus Ren, 1995 [98]) after his study of the specimen with the dorsal and underside body sclerites, mandibles, one antennae and left anterior leg. Its holotype elytron has five veins, two rows of cells between them, and very wide explanate sides with dense microtuberculation. Besides, the original drawing shows subparallel veins ([98]: 77: Figures 3-37), although his photographs of Diluticupes impressus ([98]: Pl. 11,1-2) make it possible to trace fused A1 and Cu. The additional 
specimen of this species studied by Jarzembowski et al. [108] clearly shows this fusion. Nevertheless, the name Diluticupes was synonymized with Brochocoleus to no purpose [11,29]. Tan et al. [115] divided the species mixture of Brochocoleus with Diluticupes into two groups as the "Brochocoleus punctatus series" and "B. minor series", which more or less correspond to the division into the genera here accepted. Thus, the genus Diluticupes can reasonably include all members of the "Brochocoleus minor series" sensu Tan et al. [115].

The re-examined holotype of "Brochocoleus indibili" Soriano et Delclòs. 2006 [116] (Spain, Sierra del Montsec (La Cabrua outcrop), Lower Cretaceous, Early/Lower Barremian, -130.0-125.5 Ma) is so badly preserved that it is impossible to be sure that this species is really a member of Diluticupes because of the absence of any strict evidence for its archostematan attribution. The prothorax of the latter species with the very widely explanate sides and strongly excised anterior edge is very different from that in the species of both Brochocoleus and Diluticupes. The procoxae of the above-mentioned specimen are scarcely traceable to clarify if they are contiguous for a supposition on a probable similarity with ommatines (as was supposed by the descriptors). Therefore, "Brochocoleus indibili" should be regarded as a species without generic, family and subordinal attribution (incertae sedis).

Finally, Brochocoleus angustus Tan, Ren et Shih, 2007 [115] should be regarded as a member of the genus Pareuryomma [Pareuryomma angustum, comb. nov.] because of its rather slender body, characteristic head structure, narrow prothorax and reduced cells and venation on its elytra, and also because of the comparatively large cells on the explanate elytral sides. See also the Notes to the genus Pareuryomma.

Genus Burmocoleus Kirejtshuk, gen. nov. (Figures 5 and 6). Type species: Burmocoleus prisnyi Kirejtshuk, sp. nov. Two species.

Another congener: Burmocoleus zhiyuani (Liu, Tan, Ślipiński, Jarzembowski, Wang, Ren et Pang, 2017) [117], comb. nov. [Brochocoleus].

Myanmar: Kachin (Hukawng Valley, Burmese amber); Lower/Upper Cretaceous, Albian/Cenomanian, -99.7-94.3 Ma.

Note. See below the Descriptions of new taxa of the subfamily Ommatinae.

Genus Cionocoleus Ren, 1995 [98] (Figure 4C-F). Type species: Cionocoleus magicus Ren, 1995 [98], by monotypy. 13 species.

Other congeners: Cionocoleus cervicalis Tan, Ren et Shih, 2007 [116] (Figure 4C-E), Cionocoleus elizabethae Jarzembowski, Yan, Wang et Zhang, 2013 [118], Cionocoleus jepsoni Jarzembowski, Yan, Wang et Zhang, 2013 [118], Cionocoleus longicapitis Soriano et Declós, 2006 [116], Cionocoleus minimus Jarzembowski, Yan, Wang et Zhang, 2013 [118], Cionocoleus olympicus Jarzembowski, Yan, Wang et Zhang, 2013 [118], (?) Cionocoleus ommamimus Ponomarenko, 1997 [106], Cionocoleus planiusculus Tan, Ren et Shih, 2007 [115] (Figure 4F), (?) Cionocoleus punctatus (Martynov, 1926) [119] [Carabopteron], (?) Cionocoleus sibiricus Ponomarenko, 2000 [73], Cionocoleus tanae Jarzembowski, Yan, Wang et Zhang, 2013 [118], Cionocoleus watsoni Jarzembowski, Yan, Wang et Zhang, 2013 [118].

United Kingdom: England (Smokejacks Brickworks), Lower Cretaceous, Lower Barremian, -130.0-125.5 Ma; England, (Durlston Bay), Lower Cretaceous, Late/Upper Berriamian, -145.5-140.2 Ma; Surrey, (Clockhouse Brickworks), Lower Cretaceous, Valanginian/Hauterivian, -136.4-130.0 Ma.

Spain, La Pedrera de Rubies (La Pedrera de Meià, Montsec), Lower Cretaceous, Early/Lower Barremian, -130.0-125.5 Ma.

Russia: Chita Region (Semen Creek), Lower Cretaceous, Early/Lower Aptian, -125.5-122.5 Ma.

Kazakhstan: Chimkent Region (Galkino, East Karatau), Middle/Upper Jurassic, Callovian to Callovian/Oxfordian, -164.7-155.7 Ma.

Mongolia: Uverkhangai Aimag (Anda-Khuduk), Lower Cretaceous, Aptian, -125.5-112.6 Ma.

China: Nei Mongol (Yangshuwanzi), Lower Cretaceous, Lower Aptian, -125.5-122.5 Ma; Liaoning

Province (Dawangzhangzi), Lower Cretaceous, Lower Aptian, -125.5-122.5 Ma; Liaoning Province, 
(Jianshangou, Chaomidian), Lower Cretaceous, Early/Lower Aptian, -125.5-122.5 Ma; Beijing Shi (Chongqing Reservoir), Lower Cretaceous, Late/Upper Aptian, -122.5-112.6 Ma.

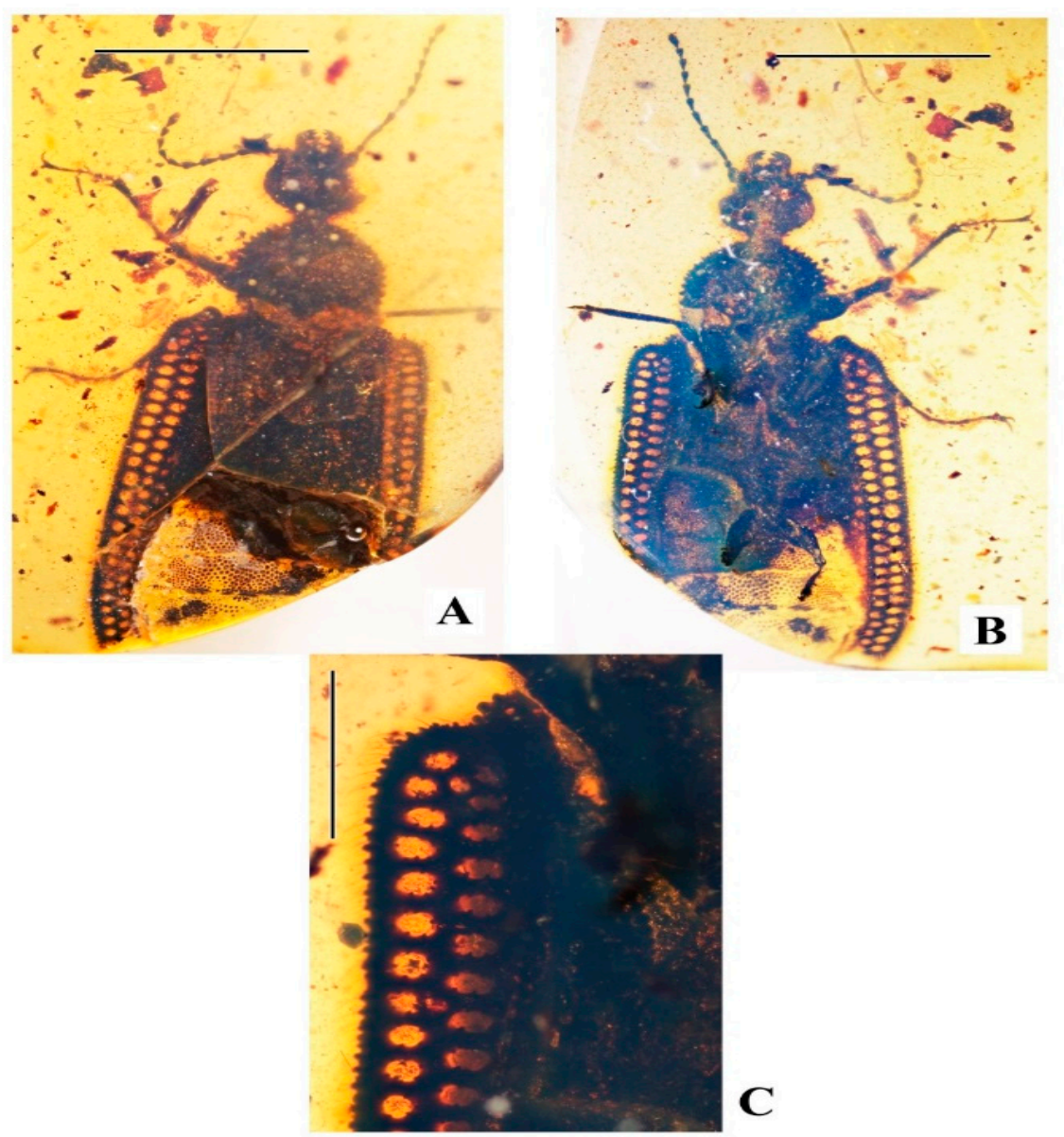

Figure 5. Ommatinae (Cupedidae): Burmocoleus prisnyi sp. nov., holotype ZIN Cuped 002 (Lower/Upper Cretaceous: Upper Albian/Lower Cenomanian; Myanmar, Kachin, Burmese amber): A—beetle, dorsal, B-same, ventral, C-lateral part of elytral base, ventral; length of inclusion $14.8 \mathrm{~mm}$, scale bar for A and $\mathbf{B}=5.0 \mathrm{~mm}$, scale bar for $\mathbf{C}=2.0 \mathrm{~mm}$; original.

Notes. After the current studies of Jarzembowski et al. [118] the position of this group became rather clarified. This genus is characterized by the elongate body with finely and diffusely microreticulated integument, comparatively long head with rather small eyes and slightly expressed neck, prothorax subspherical with incarinate sides, elytra somewhat explanate at sides and their lateral edges smooth (not densely serate) and without clear veins or at most reduction or lack of cell development on the elytra, abdominal ventrites co-planar (abutting). The polygonal (to subquadrate) cells are apparently located along the elytral lateral edges and arranged in weakly expressed longitudinal rows. The prothorax of some species of Cionocoleus seems to have no or apparently only weak remnants of lateral carinae.

Cionocoleus ommamimus does not fit with other congeners as its head has prominent temples, its elytra are extremely narrowly explanate at the sides, and its abdominal ventrites could be overlapping. The descriptor drawing ([105]: 54, Figure 13) shows a prothorax different from his photograph ([105]: Pl. VI, 16), but it seems that the prothorax of Cionocoleus ommamimus is indeed incarinate. Jarzembowski et al. [118] placed Cionocoleus punctatus in the genus Cionocoleus, although its longitudinal seriation in the elytral sculpture and apparently extremely narrowly explanate sides of the elytra give reasons to doubt of this attribution (some longitudinal seriation is also visible in the photograph of 
Cionocoleus ommamimus). At the same time Cionocoleus tanae looks like a quite typical member of this genus despite strongly reduced explanate sides of the elytra.

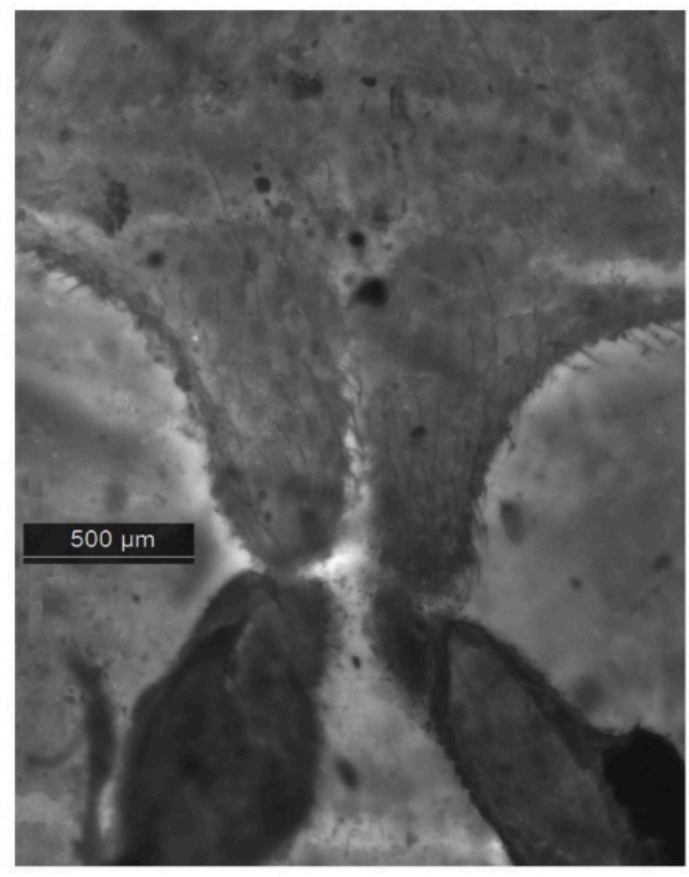

A

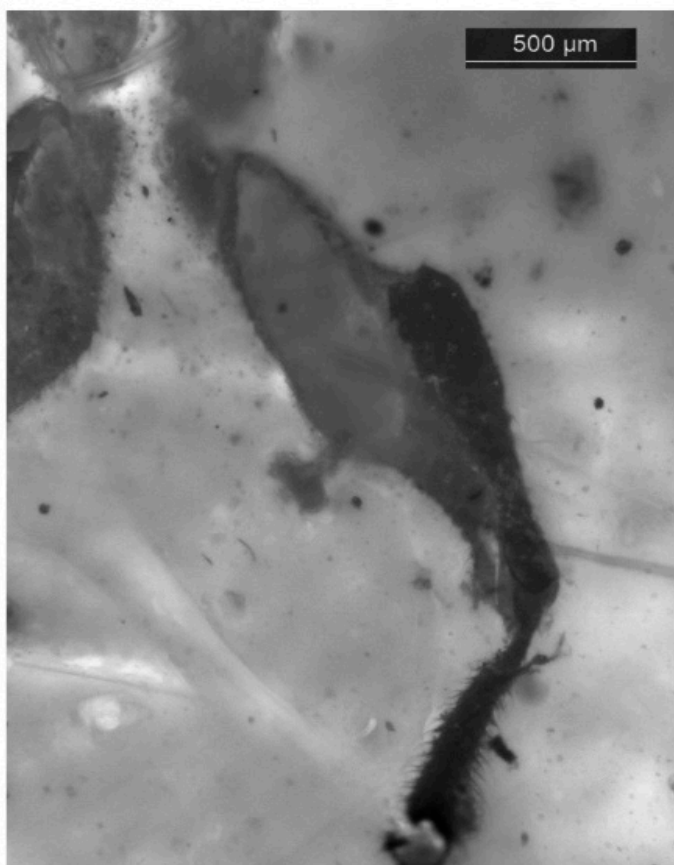

C

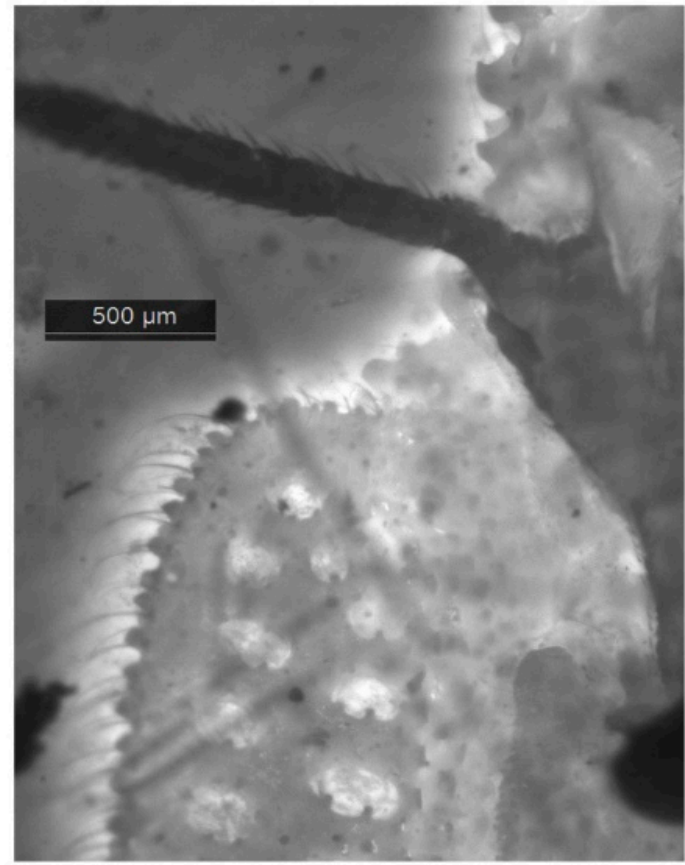

B

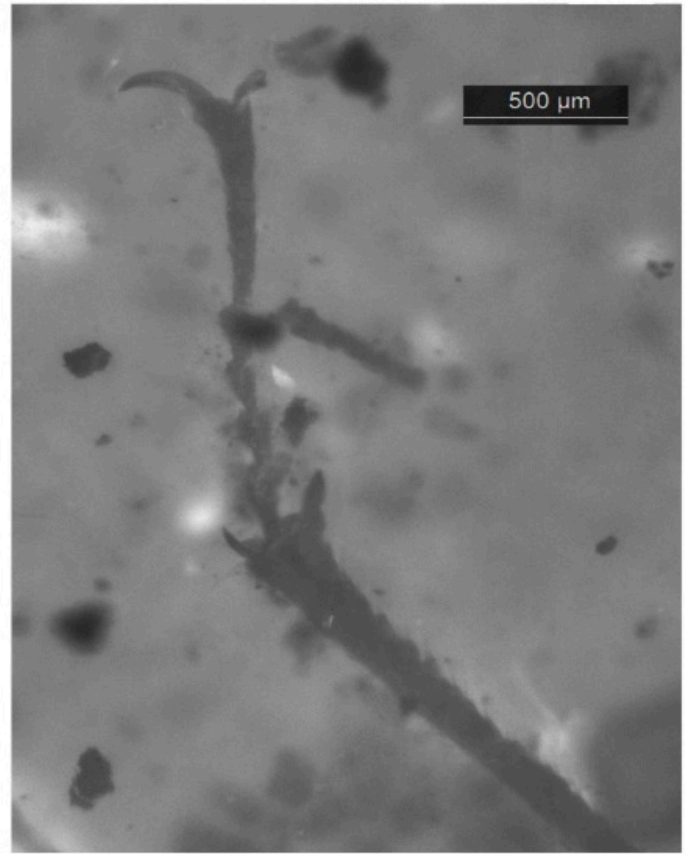

D

Figure 6. Ommatinae (Cupedidae): Burmocoleus prisnyi sp. nov., holotype ZIN Cuped 002 (Lower/Upper Cretaceous: Upper Albian/Lower Cenomanian; Myanmar, Kachin, Burmese amber); fluorescent microscopy with filter set N21: A-metacoxa, B-lateral part of elytral base, ventral, C-metafemur and metatibia, ventral, D-protibia and protarsus; length of inclusion $14.8 \mathrm{~mm}$; scale for each picture provided; original. 

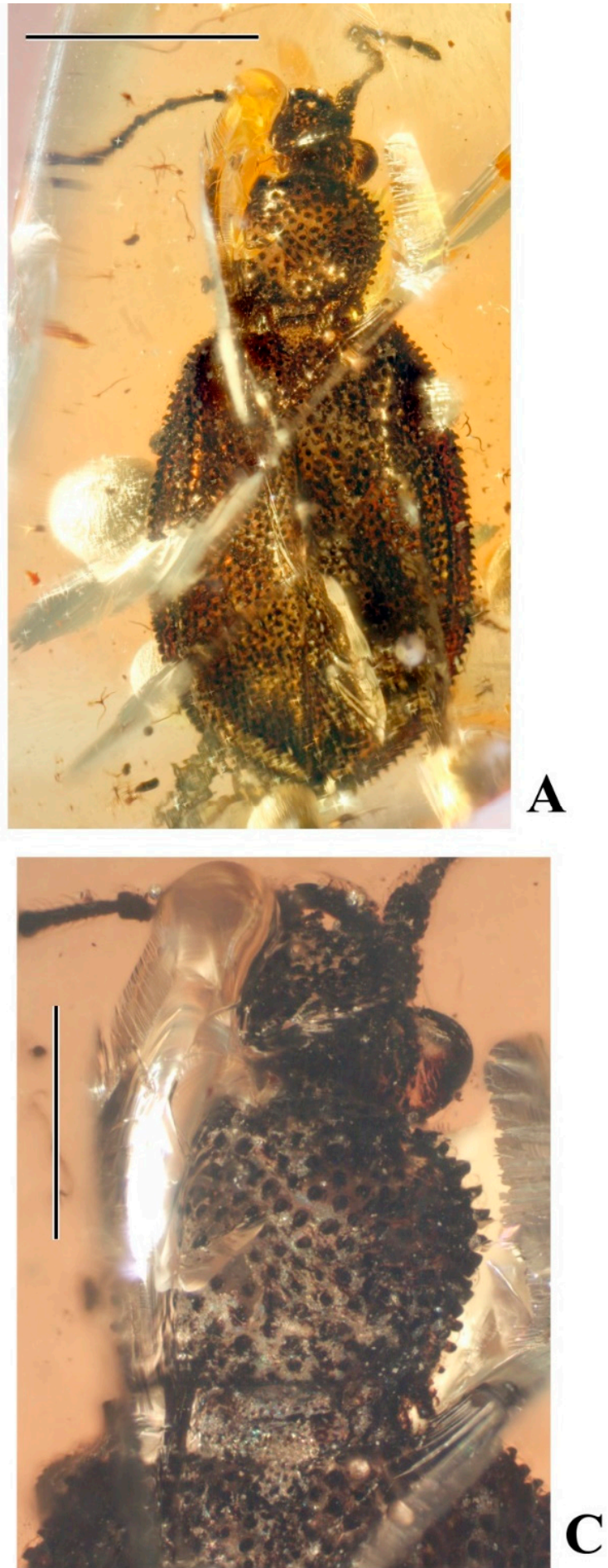

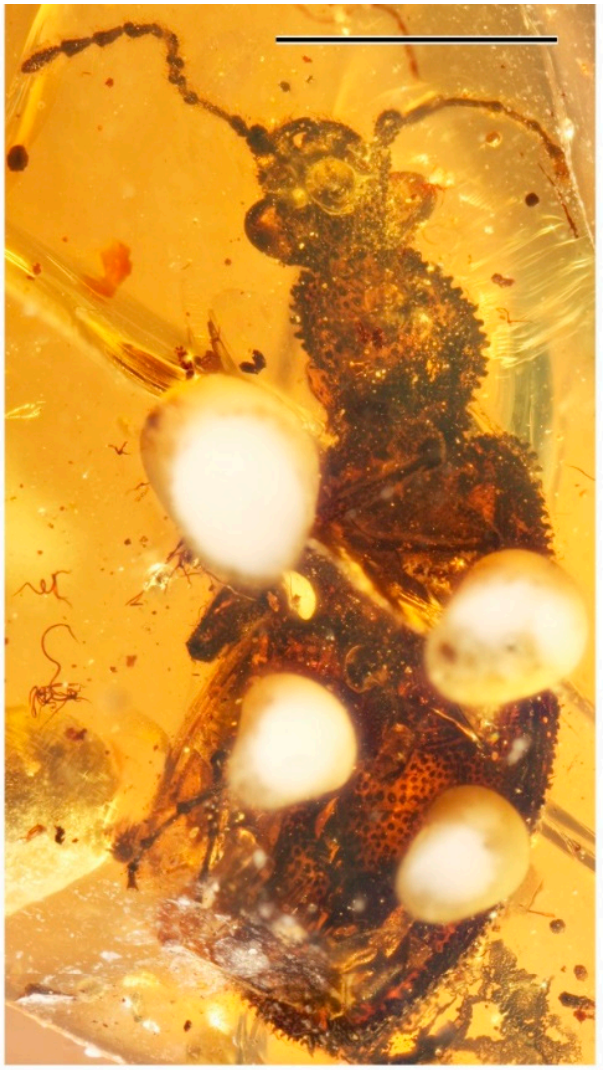

B

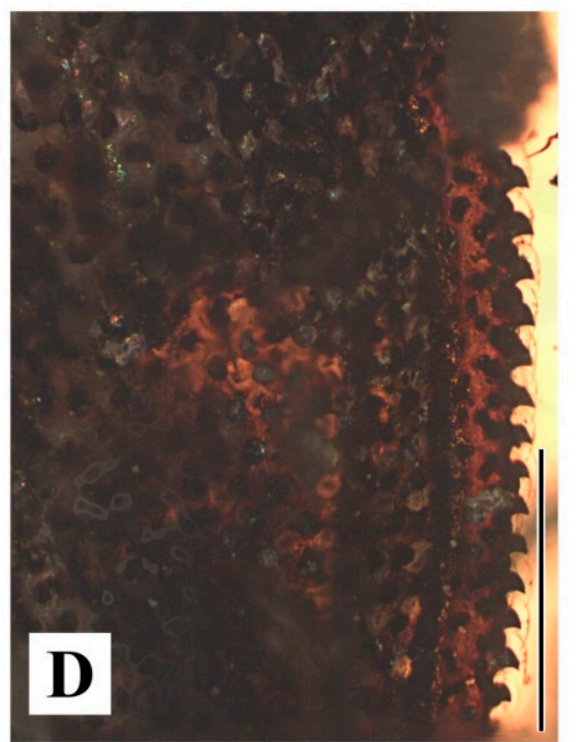

Figure 7. Ommatinae (Cupedidae): Cionoccups manukyani sp. nov., holotype GPIH 4984, coll. C. Gröhn 11186 (Lower/Upper Cretaceous: Upper Albian/Lower Cenomanian; Myanmar, Kachin, Burmese amber): A-beetle, dorsal, B-same, ventral, C-head and prothorax, dorsal; D-elytral side, dorsal; length of inclusion $7.3 \mathrm{~mm}$, scale bar for $A$ and $B=2.5 \mathrm{~mm}$, scale bar for $C=1.4 \mathrm{~mm}$, scale for $\mathrm{D}=0.8 \mathrm{~mm}$; original. 

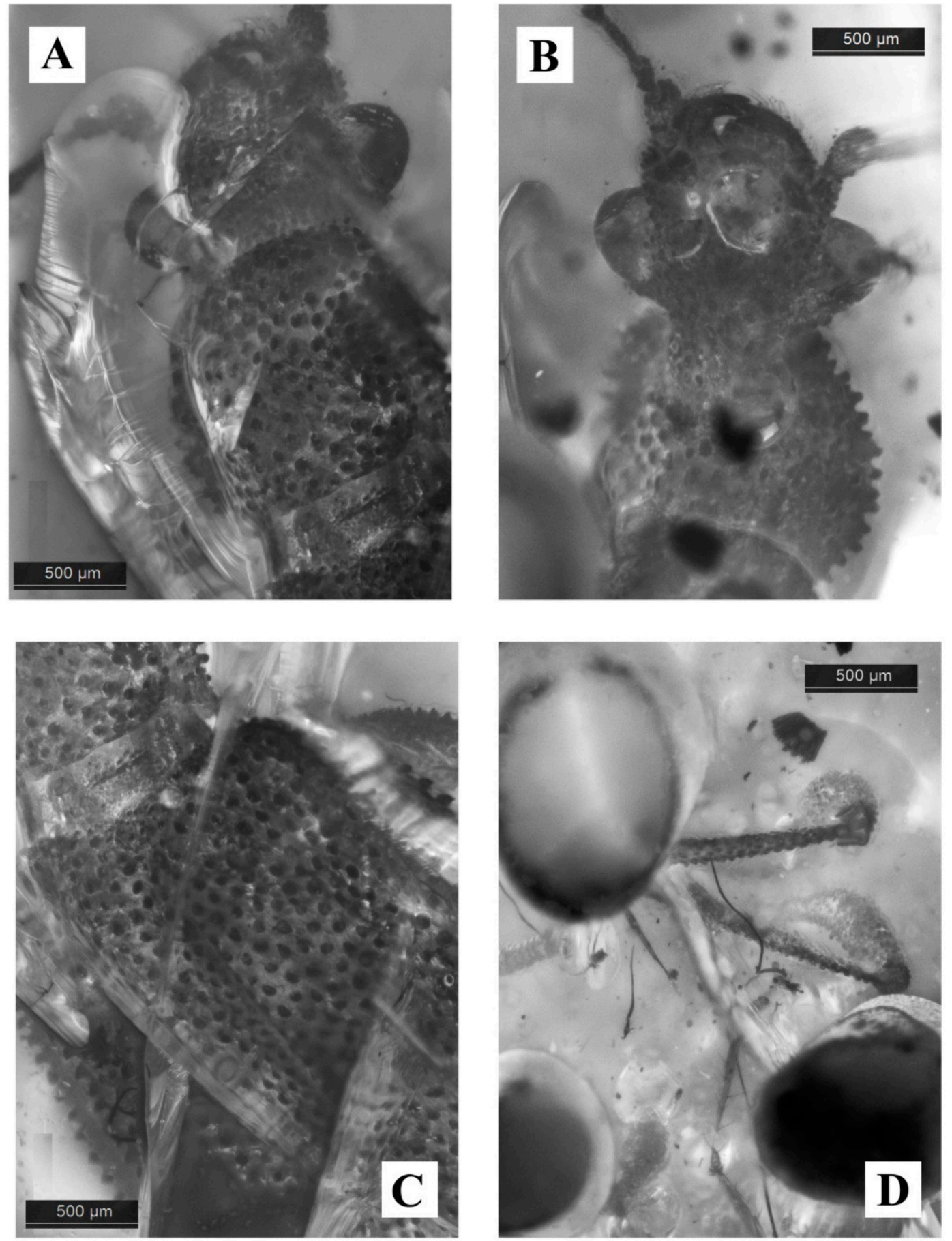

Figure 8. Ommatinae (Cupedidae): Cionocups manukyani sp. nov., holotype GPIH 4984, coll. C. Gröhn 11,186 (Lower/Upper Cretaceous: Upper Albian/Lower Cenomanian; Myanmar, Kachin, Burmese amber); fluorescent microscopy with filter set N21: A-head and prothorax, dorsal, B—same, ventral, C-prothoracic and elytral bases, dorsal, D-intermediate and posterior legs; length of inclusion $7.3 \mathrm{~mm}$; scale for each picture provided; original. 

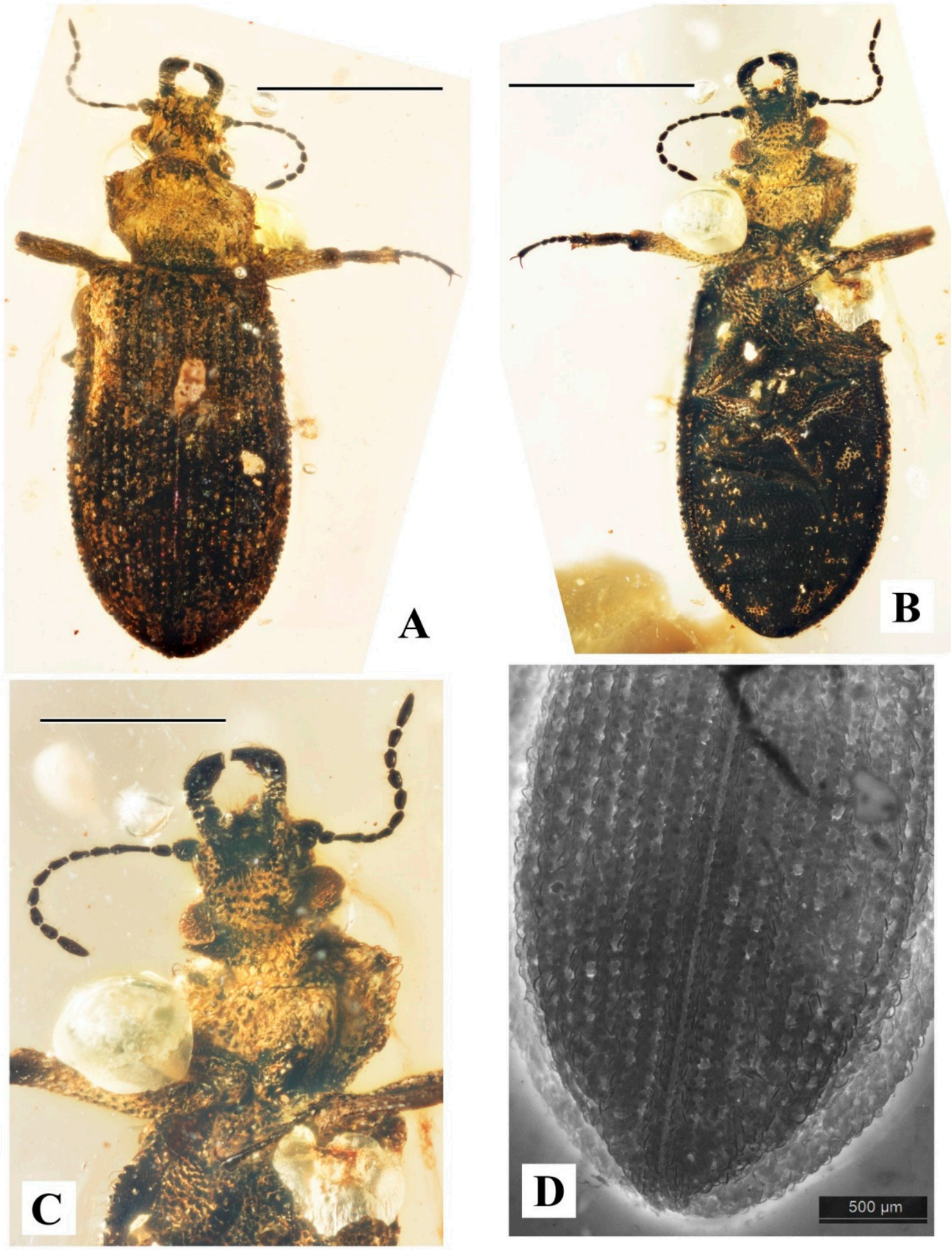

Figure 9. Ommatinae (Cupedidae): Clessidromma zengi sp. nov., holotype ZIN Cuped 003 (Lower/Upper Cretaceous: Upper Albian/Lower Cenomanian; Myanmar, Kachin, Burmese amber): A-beetle, dorsal, B-same, ventral, C - anterior part of body, ventral; D-elytra, dorsal (fluorescent microscopy with filter set L5); length of inclusion $6.2 \mathrm{~mm}$ of, scale bar for A and B = $2.0 \mathrm{~mm}$, scale bar for C $=1.0 \mathrm{~mm}$, scale for $\mathrm{D}$ shown with indication $\mathrm{mm}$; original. 

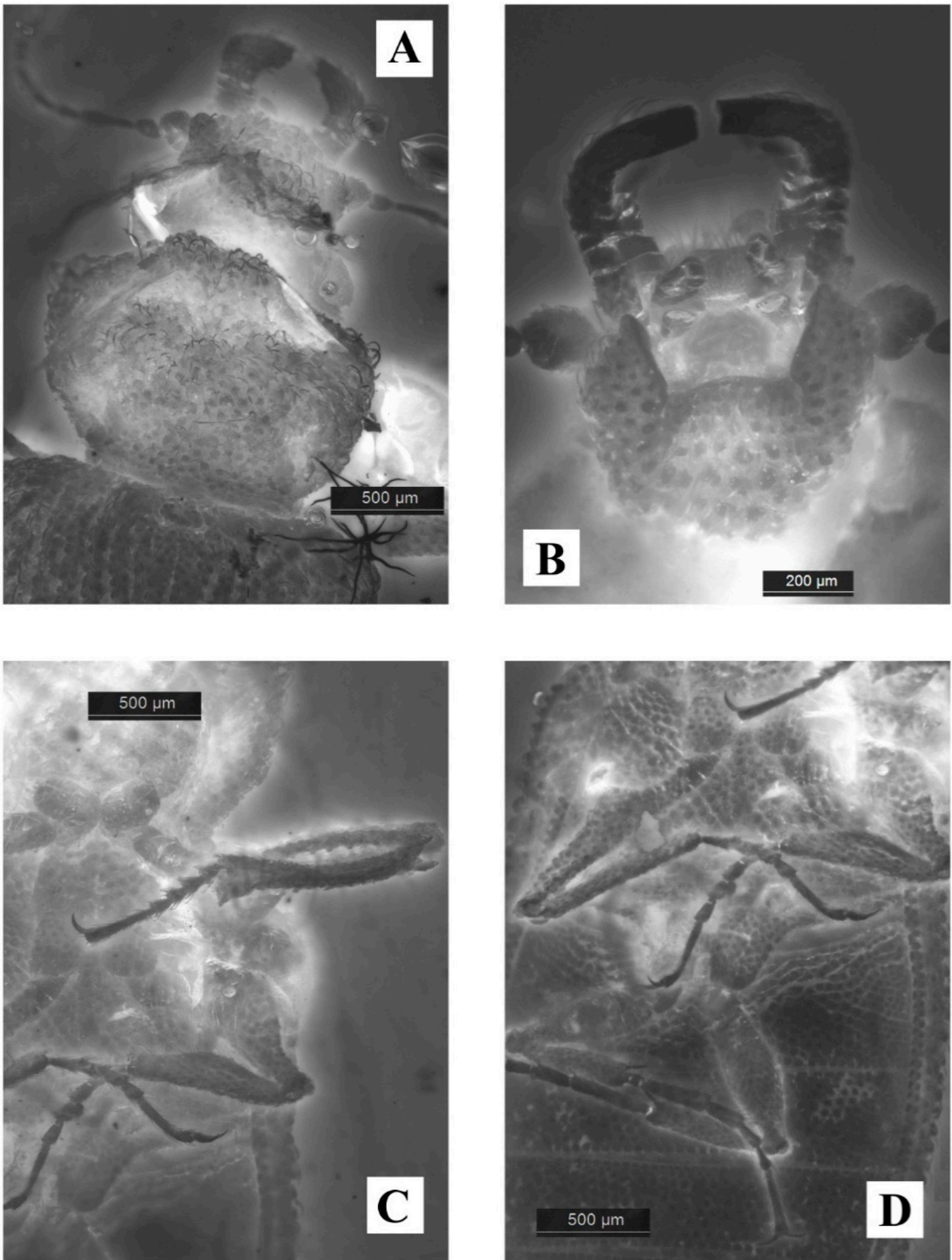

Figure 10. Ommatinae (Cupedidae): Clessidromma zengi sp. nov., holotype ZIN Cuped 003 (Lower/Upper Cretaceous: Upper Albian/Lower Cenomanian; Myanmar, Kachin, Burmese amber): A-beetle, dorsal, B-same, ventral, C - anterior part of body, ventral; D-elytra, dorsal; fluorescent microscopy with filter set L5 for A and B, and also filter set N21 for C and E; length of inclusion $6.2 \mathrm{~mm}$, scale for each picture provided; original.

Genus Cionocups Kirejtshuk, gen. nov. Type species Cionocups manukyani Kirejtshuk, sp. nov. One species.

Myanmar: Kachin (Hukawng Valley, Burmese amber), Lower/Upper Cretaceous, Albian/Cenomanian, -99.7-94.3 Ma. 
Note. This new genus is rather similar to Cionocoleus, but, in contrast to the latter, has the peculiar shape of the head with very large eyes and rather narrow neck, much longer antennae, dorsal integument with dense and high coarse microtubercles, on the elytra microtubercles are intermixed with small oval cells (primary window punctures) apparently comparable in size with microtubercles, and elytral sides with distinctly serrate lateral edges (Figures 7 and 8) (see below the Description of the subgenus Cianocups subgen. nov).

Genus Clessidromma Jarzembowski, Wang et Zheng, 2017 [101] (Figures 9 and 10). Type species Clessidromma palmeri Jarzembowski, Wang et Zheng, 2017 [101], by monotypy (=Lepidomma Jarzembowski, Wang et Zheng, 2019 [120], syn. nov., type species: Lepidomma tianae Jarzembowski, Wang et Zheng, 2019 [120], by monotypy. Three species.

Congeners: Clessidromma palmeri, Clessidromma tianae comb. nov., Clessidromma zengi sp. nov.

Myanmar: Kachin (Hukawng Valley, Burmese amber); Lower/Upper Cretaceous, Albian/Cenomanian, -99.7-94.3 Ma.

Notes. This genus is variable in body shape, but characterized by the more or less expressed "neck-like" base and projecting and explanate anterior portion of the pronotum, most or at least middle part of the pronotal sides subflattened and serrate (distinctly carinate), long mesoventrite, very short metaventrite, shoulders strongly projecting anteriorly, elytral microtuberculation well developed (passing into serration), elytral striation less so, cells small (obscured), metafemur and metatibia markedly shorter than the corresponding sclerites of the anterior and intermediate legs, metatarsus considerably longer than pro-and mesotarsi, flat (co-planar) abdominal ventrites.

Clessidromma palmeri is very similar to Lepidomma tianae and differs from the latter only in the outlines of body sclerites giving an impression that the first is the second, which was strongly extended in length. The third species recovered during the recent studies looks like somehow intermediate between the first and second species described before, although every of these three species has some additional specific diagnostic features $[101,120]$ (see below the Descriptions of new taxa of the subfamily Ommatinae).

Genus Diluticupes Ren, 1995 [98], ! distinct genus. Type species Diluticupes impressus Ren, 1995 [98], by monotypy. Seven species.

Other congeners: (?) Diluticupes applanatus (Tan et Ren, 2009) [121], comb. nov. [Brochocoleus], Diluticupes crowsonae (Jarzembowski, Yan, Wang et Zhang. 2013) [112], comb. nov. [Brochocoleus], (?) Diluticupes magnus (Tan et Ren, 2009) [121], comb. nov. [Brochocoleus], Diluticupes minor (Ponomarenko, 2000) [73], comb. nov. [Brochocoleus], Diluticupes validus (Tan et Ren, 2009) [121], comb. nov. [Brochocoleus], Diluticupes yangshuwanziensis (Jarzembowski, Yan, Wang et Zhang. 2013) [112], comb. nov. [Brochocoleus].

United Kingdom: England (Smokejacks Brickworks), Lower Cretaceous, Lower Barremian, $-130.0-125.5 \mathrm{Ma}$.

Russia: Chita Region (Semen Creek), Lower Cretaceous, Lower Aptian, -125.5-122.5 Ma.

China: Nei Mongol (Daohugou), Middle/Upper Jurassic, Callovian/Oxfordian, -164.7-155.7 Ma; Nei Mongol (Yangshuwanzi, Ningcheng County), Lower Cretaceous, Lower Aptian, -125.5-122.5 Ma; Beijing Shi (Chongqing Reservoir), Lower Cretaceous, Upper Aptian, -122.5-112.6 Ma.

Note. See the above Notes to the genus Brochocoleus. "Brochocoleus" applanatus and "B." magnus were initially treated by the descriptors as members of the punctatus-series [121], i.e., Brochocoleus sensu stricto. These authors mentioned that the "epipleura" of these species have rows of cells. At the same time, their photographs show the rather fine sculpture of these parts of elytra, which is different from that in genuine Brochocoleus species [121]. Moreover, despite both holotypes being represented by the prints of the beetles' underside, the descriptors drew the traced elements of the upper surface of "Brochocoleus" applanatus with veins on elytra, including the distal fusion of $\mathrm{Cu}$ and $\mathrm{M}$ (may be erroneous instead of fusion of $\mathrm{A} 1$ and $\mathrm{Cu}$ ). However such fusion is characteristic of Diluticupes but not 
Brochocoleus. Nevertheless the final conclusion on the generic attribution of "Brochocoleus" applanatus and "B." magnus will be possible after a further re-examination of the type specimens of both species and checking their current interpretations in the composition of Diluticupes.

Genus Eurydictyon Ponomarenko, 1969 [26]. Type species Eurydictyon conspicuum Ponomarenko, 1969 [26], by monotypy. One species.

Kyrgyzstan: Osh Region (Kyzyl-Kiya); Lower Jurassic, Pliensbachian, -189.6-183.0 Ma.

Notes. This genus is characterised by the wide robust body with the elongate head having the scape longest and thickest among the antennomeres, very short and very wide prothorax having the distinct lateral carinae, elytra having fused $\mathrm{A} 1$ and $\mathrm{Cu}$ independently ending on the suture (as well as all other veins), radial field with two rows of cells only at base but most of the length of this field with one row of cells and explanate sides also with one row of cells, abdominal ventrites apparently overlapping.

Genus Jarzembowskops Kirejtshuk, gen. nov. Type species: Brochocoleus caseyi Jarzembowski, Wang et Zheng, 2016 [122], by monotypy. One species.

Myanmar: Kachin (Hukawng Valley, Burmese amber): Lower/Upper Cretaceous, Albian/Cenomanian, -99.7-94.3 Ma.

Note. See below the Descriptions of new taxa of the subfamily Ommatinae.

Genus Liassocupes Zeuner, 1962 [123]. Type species Liassocupes parous Zeuner, 1962 [123], by monotypy. One species.

United Kingdom: England (Charmouth, Dorset); Lower Jurassic, Upper Sinemurian, -196.5-189.6 Ma.

Notes. This genus has a rather long head with long frons before the eyes (and with very short temples), eyes displaced dorsally, so that interocular distance is less than eye diameter; rounded sides of pronotum, elytron with parallel rows of cells and veins apparently ending on Sc, and abdominal ventrites co-planar (abutting). It is impossible to make a conclusion on presence or absence of the lateral carinae of the prothorax without re-examination of the type specimen and especially the abnormal disposition of the eyes.

Whalley [112] described another species, Liassocupes (?) maculatus Whalley, 1985 [112] (United Kingdom: England (Charmouth, Dorset), Lower Jurassic, Upper Sinemurian, -196.5-189.6 Ma), which could be a member of this genus; however Ponomarenko [112] considered that this species is a member of "Omma" or "Tetraphalerus" rather than Liassocupes. Also Whalley [112] described another species, Liassocupes (?) giganteus Whalley, 1985 [112] (United Kingdom: England (Charmouth, Dorset); Lower Jurassic, Upper Sinemurian, -196.5-189.6 Ma), which according to Ponomarenko (2006) could be better assigned to the genus Mimema Handlirsch, 1906 [1] (Schizocoleidae Rohdendorf, 1961).

Genus Lithocupes Ponomarenko, 1966 [102]. Type species Lithocupes incertus Ponomarenko, 1966 [102], by monotypy. Three species.

Other congeners: Lithocupes gigas Ponomarenko, 1969 [26], Lithocupes punctatus Ponomarenko, 1969 [26].

Kyrgyzstan: Osh Region (Kyzyl-Kiya), Lower Jurassic, Pliensbachian, -189.6-183.0 Ma.

Notes. This genus is distinct due to its head having very short temples, pronotum transverse and widest at base, prothorax with clear lateral carinae, elytra with weakly expressed veins and subparallel longitudinal rows of cells independently ending along the lateral elytral edge. The abdominal ventrites in species of this genus are overlapping.

Genus Monticupes Ren, 1995 [98] (Figure 11). Type species: Monticupes surrectus Ren, 1995 [98], by original designation. Four species. 

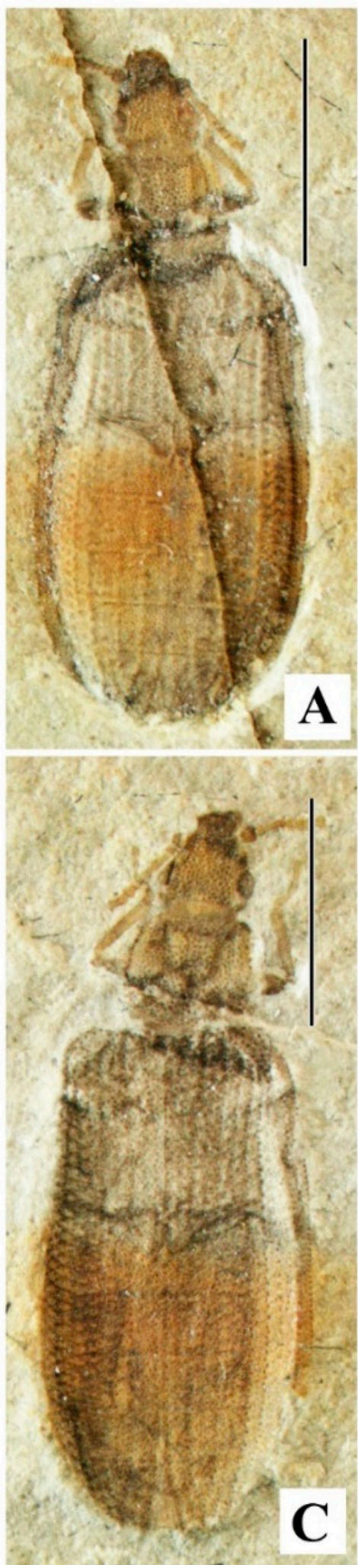
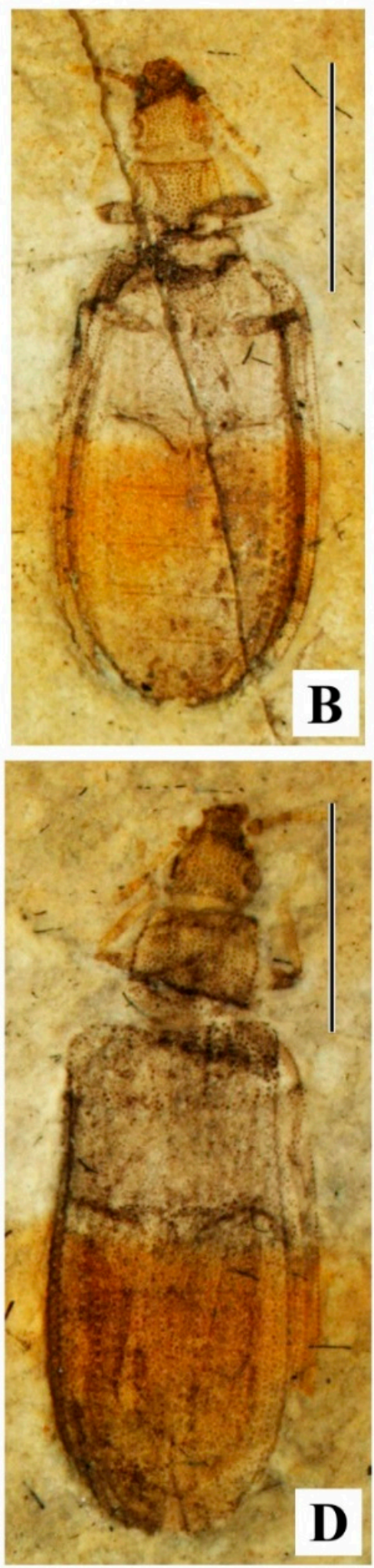

Figure 11. Ommatinae (Cupedidae): A-D-Monticupes curtinervis comb. nov. [Tetraphalerus], holotype CNU-C-LB2006006-1, part, CNU-C-LB2006006-2, counterpart (Lower Cretaceous, Lower Aptian Liaoning, Chaomidian): A-part, dry, B-same, wettened by alcohol; C-counterpart, dry and D-same, wettened by alcohol; length of print $11.5 \mathrm{~mm}$, scale bar $=3.9 \mathrm{~mm}$; original. 
Other congeners: Monticupes curtinervis (Tan, Ren et Shih, 2007) [106], comb. nov. [Tetraphalerus] (Figure 11), Monticupes decorosus (Tan, Wang, Ren et Yang, 2012) [124], comb. nov. [Tetraphalerus], Monticupes fentaiensis Ren, 1995 [98].

China: Beijing Shi (Chongqing Reservoir), Lower Cretaceous, Late/Upper Aptian, -122.5-112.6 Ma; Liaoning Province (Huangbanjigou, Chaomidian Village), Lower Cretaceous, Lower Aptian, -125.5-122.5 Ma; Nei Mongol (Daohugou), Middle/Upper Jurassic, Callovian/Oxfordian, -164.7-155.7 Ma.

Notes. The drawing reconstructions of the type species ([98]: 76, Figures 3-34) are different from its photographs in the main diagnostic character ([98]: Pl. 10, Figures 4 and 5); nevertheless, it is clear that the elytra of the holotype have a fused A1 and $\mathrm{Cu}$ at the apex. The head of the type species also has differences in the author's illustrations mentioned above and is needs to be checked by a re-examination of the type specimen. Thus, Monticupes is characterized by the moderately oval body, subtriangular or long (subparallelsided) head with large eyes and well raised temples, pronotum carinate and with subexplanate sides, veins well expressed with fused A1 and $\mathrm{Cu}$ at apex and their common vein ending on Sc, explanate elytral sides moderately wide and with diffuse small microtubercles, and abdominal ventrites co-planar (abutting). The head of the type species also has differences in the author's illustrations mentioned above and also needs to be checked by a re-examination of the type specimen. The members of this genus, in contrast to those of Allophalerus gen. nov., demonstrate the fusion of $\mathrm{A} 1$ and $\mathrm{CuA}$ at the elytral apex and different shape of their head (see below the comparison of Allophalerus gen. nov.)

Genus Notocupoides Ponomarenko, 1966 [102]. Type species Notocupoides triassicus Ponomarenko, 1966 [102], by original designation. Three species.

Other congeners: Notocupoides capitatus Ponomarenko, 1966 [102], Notocupoides fasciatus Ponomarenko, 1966 [102].

Kyrgyzstan: Osh Region (Madygen, Northern area and Dzhailoucho area); Middle/Upper Triassic, Ladinian/Carnian, -235.0-221.5 Ma.

Notes. The most peculiar feature of this genus is that the elytra of its species have well expressed veins and longitudinal rows of cells reaching the sutural edge without fusion. Besides, Notocupoides is characterized by the long head with short temples and long frons before the eyes, rather wide pronotum with widely explanate and carinate sides, intervenal stripes of the elytra with two cells in longitudinal rows, explanate sides with one row of rather large cells, rather short antennae, and abdominal ventrites overlapping.

Genus Odontomma Ren, Tan et Ge, 2006 [125] (Figure 12). Type species Odontomma trachylaenum Ren Tan et Ge, 2006 [125] (lapsus calami: "trachylaenus") (Figure 12A,B), by monotypy. Two species.

Another congener: Odontomma sulcatum (Tan, Ren et Shih, 2007) [115], comb. nov. [Brochocoleus] (Figure 12C-E).

China: Nei Mongol (Yangshuwanzi, Ningcheng County), Lower Cretaceous, Lower Aptian, -125.5-122.5 Ma; Liaoning Province (Huangbanjigou, Chaomidian Village), Lower Cretaceous, Lower Aptian, -125.5-122.5 Ma.

Notes. This genus is rather similar to Diluticupes, but the veins of Odontomma elytra are not fused at the apices and the head of its members, in contrast to species of Diluticupes, is longer and not narrowed anteriorly. Thus Odontomma is characterized by the moderately oval body, moderately more or less long and subparallel or oviform head with comparatively small eyes, rather wide pronotum with the widely explanate carinate sides, all veins ending on Sc along the lateral elytral edge, veins well expressed, explanate elytral sides with diffuse small microtubercles, and abdominal ventrites co-planar (abutting) or looking like bordered along the posterior edge.

Genus Omma Newman, 1839 [100] (Figures 13 and 14). Type species: Omma stanleyi Newman, 1839 [100], recent, by monotypy (=Chalepocarabus Handlirsch, 1906 [1], type species: Carabus elongatus 
Brodie, 1845 [126]; Pyrochroophana Handlirsch, 1906 [1]; type species: Pyrochroa brevipes Deichmüller, 1886 [127], by original designation, Ommamima Ponomarenko, 1964 [103]; type species: Ommamima pilosum Ponomarenko, 1964 [103], by monotypy); (?) Procarabus Oppenheim, 1888 [128], type species: Procarabus zitteli Openheim, 1888 [128], designated by Ponomarenko, 1971 [129]. 18 species.
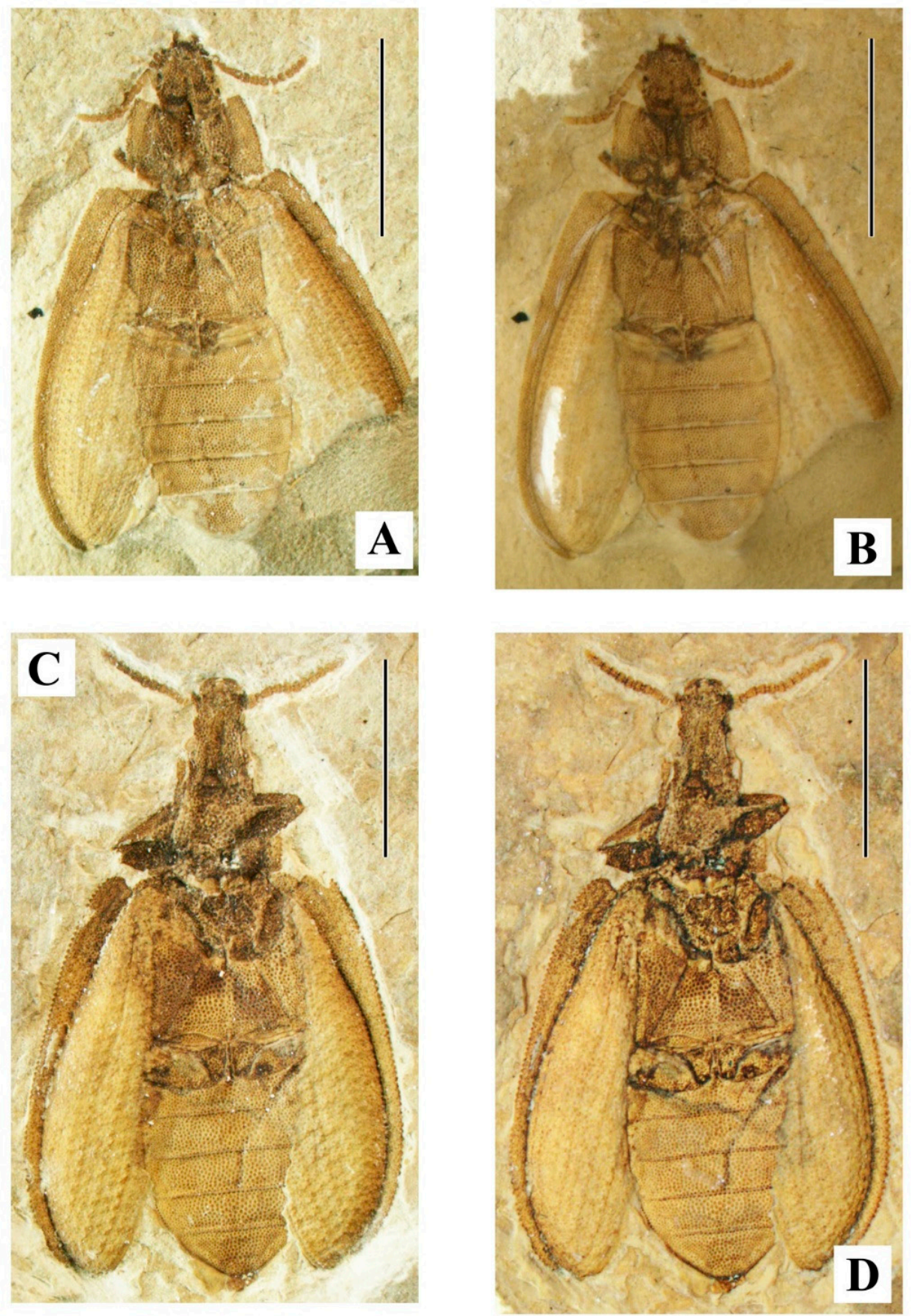

Figure 12. Ommatinae (Cupedidae): A-B-Odontomma sulcatum comb. nov. [Brochocoleus], holotype CNU -C-LB2006011-1, part (Lower Cretaceous, Lower Aptian Liaoning, Chaomidian): A-dry and B-wettened by alcohol; length of print $13.5 \mathrm{~mm}$, scale bar $=2.9 \mathrm{~mm}$; original. C-E-Odontomma trachylema, holotype, part CNU -C-LB2005009-1 (Lower Cretaceous, Lower Aptian Liaoning, Chaomidian): C-dry, D -part wettened by alcohol; length of print $19.0 \mathrm{~mm}$, scale bar $=6.3 \mathrm{~mm}$; original. 
Fossil congeners: Omma aberratum Ponomarenko, 1968 [107], (?) Omma altajense Ponomarenko, 1997 [105], Omma ancistrodontum (Tan, Wang, Ren et Yang, 2012) [124], comb. nov. [Pareuryomma] (lapsus calami: "ancistrodonta"), (?) Omma antennatum Ponomarenko, 1997 [105], Omma avus Ponomarenko, 1969 [26], Omma brevipes (Deichmüller, 1886) [127] [Pyrochroa, Pyrochroophana], (?) Omma daxishanense Cai et Huang, 2017 [130], Omma delicatum Tan, Wang, Ren et Yang, 2012 [124] (lapsus calami: "delicata"), (?) Omma elongatum (Brodie, 1845) [126] [Carabus, Chalepocarabus] (lapsus calami: "elongata"), (?) Omma gobiense Ponomarenko, 1997 [105], (?) Omma grande (Ponomarenko, 1964) [103], comb. nov. [Tetraphalerus] (Figures 13 and 14), Omma janetae sp. nov., Omma jurassicum Ponomarenko, 1968 [107], Omma liassicum Crowson, 1962 [131], Omma lii Jarzembowski, Wang et Zheng, 2016 [132], Omma longicolle (Ponomarenko, 1997) [105], comb. nov. [Tetraphalerus], Omma pilosum (Ponomarenko, 1964) [103] [Ommamima], Omma sibiricum Ponomarenko, 1966 [109], (?) Omma zitteli (Oppenheim, 1888) [128] [Procarabus].

United Kingdom: England (Flatstones, Charmouth), Lower Jurassic, Sinemurian, -196.5-189.6 Ma; England (Binton, Warwickshire), Upper Triassic/Lower Jurassic, Rhaetian/Hettangian, -201.6-196.5 Ma; England (Brown's Wood, Warwickshire), Upper Triassic, Rhaetian, -205.6-201.6 Ma; England (Hasfield), Upper Triassic, Rhaetian, -205.6-201.6 Ma; England (Norton), Upper Triassic, Rhaetian, -205.6-201.6 Ma; England, United Kingdom (Teffont, Vale of Wardour), Lower Cretaceous, Berriasian, -145.5-140.2 Ma.

Germany: Bavaria (Solnhofen), Upper Jurassic, Tithonian, -150.8-145.5 Ma.

Russia: Buryatia (Transbaikalia, Baissa), Lower Cretaceous, Aptian, -125.5-112.6 Ma.

Kazakhstan: Chimkent Region (Mikhailovka), Upper Jurassic, Callovian/Oxfordian, -164.7-155.7 Ma.

Kyrgyzstan: Tonskiy (Ak-Bulak-Say, Soguty, Issyk-Kul), Upper Triassic/Lower Jurassic, Rhaetanian/Hettangian, -201.6-189.6 Ma.

Mongolia: Bayan-Khongor Aimag (Bahar or Bakhar), Middle Jurassic, Bajocian/Bathonian, -171.6-164.7 Ma; Bayan-Khongor Aimag (Bon Tsagaan), Lower Cretaceous, Aptian, -125.5-112.6 Ma; Mongolia, Bayan-Khongor Aimag (Shar-Tolgoy), Lower Cretaceosu, Aptian, -125.5-112.6 Ma; Dund-Gov' Aimag (Khoutiyn-Khotgor), Upper Jurassic, Tithonian, -150.8-145.5 Ma.

China, Nei Mongol (Daohugou), Middle/Upper Jurassic, Callovian/Oxfordian, -164.7-155.7 Ma; Liaoning Province (Daxishan, Linglongta Township), Upper Cretaceous, Oxfordian/Kimmeridgian, -161.2-155.7 Ma.

Myanmar: Kachin (Hukawng Valley, Burmese amber), Lower/Upper Cretaceous, Albian/Cenomanian, -99.7-94.3 Ma.

Notes. This genus still remains rather problematic because of difficulties with analysis of the accessible characteristics in the descriptions and illustrations of its fossil members and comparison with the characteristics of the type species and other recent representatives. Therefore, most fossil species included here in this genus need to be re-examined. The extinct genus that is most closely related to Omma is Polyakius gen. nov., which differs from the extant genus mostly in some level of dorsoventral compression of the body, and also in the presence of one row of very large cells along the lateral elytral edges and very dense and fine dorsal vestiture.

Omma is characterized by the comparatively slender body; moderately long and subtriangular head, eyes located at base, extremely short temples; prothorax not or very slightly dorsoventrally compressed and incarinate at sides; weakly expressed elytral veins, regular longitudinal rows of moderately large cells between subparallel veins and terminating on Sc along the lateral elytral edge; narrowly explanate or not explanate elytral sides with diffuse small microtubercles or punctures on explanate parts, and abdominal ventrites co-planar (abutting). 

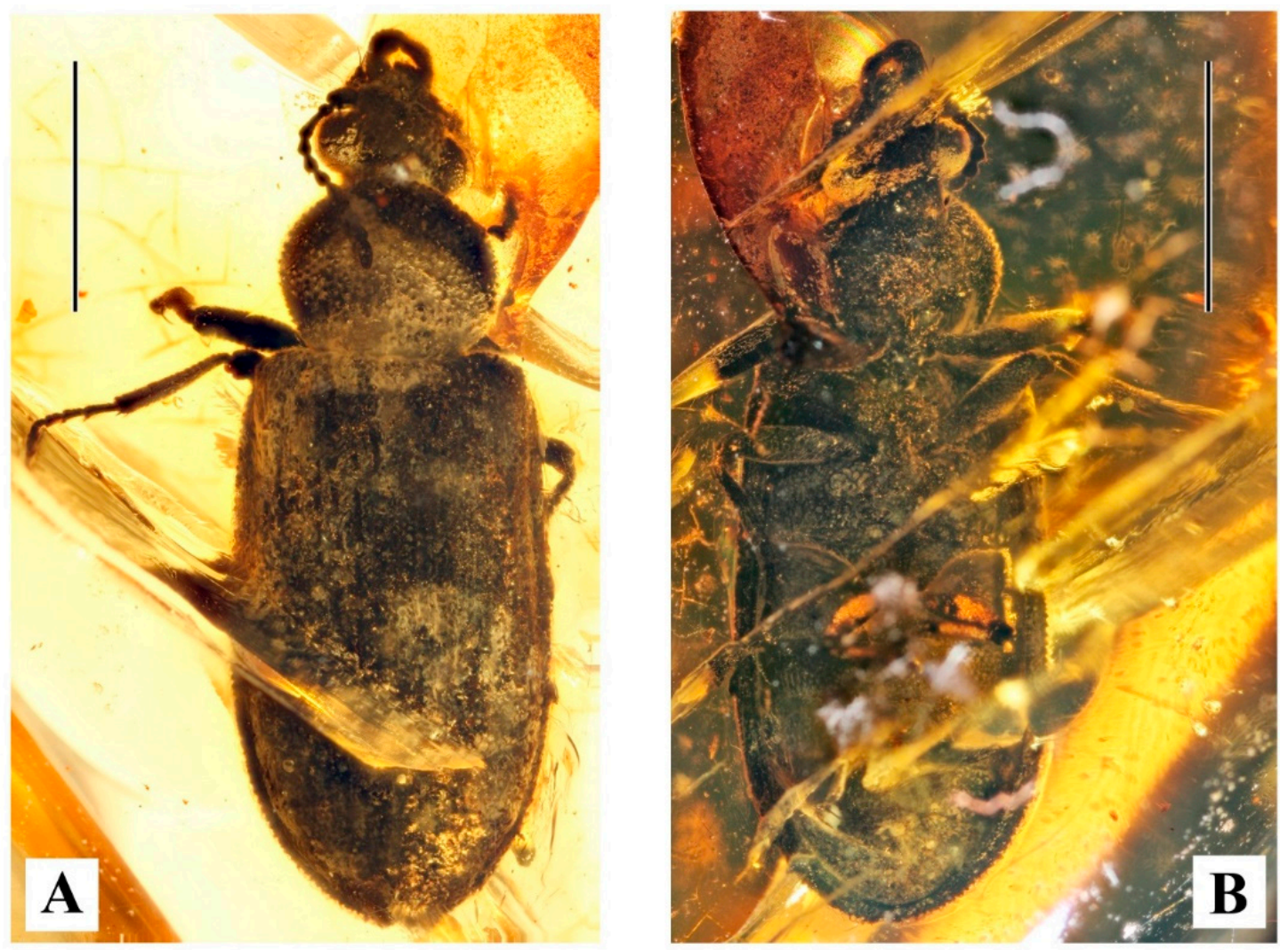

Figure 13. Ommatinae (Cupedidae): Omma janetae sp. nov., holotype ZIN Cuped 004 (Lower/Upper Cretaceous: Upper Albian/Lower Cenomanian; Myanmar, Kachin, Burmese amber): A—beetle, dorsal, B-same, ventral; length of inclusion $8.6 \mathrm{~mm}$, scale bar for $\mathbf{A}$ and $\mathbf{B}=2.4 \mathrm{~mm}$; original.

Thus, most species put in the above preliminary list of congeners can change their attribution after a detailed re-examination of their type specimens. For example, Omma altajense described after study on the underside of the metathorax and abdomen with narrow epipleura bearing a longitudinal row of "cells" but without visible elytral discs in the photograph ([105]: Pl VI, Figure 9) could be a member of Polyakius gen. nov. The same could also apply to (?) Omma gobiense having only the prothorax and head testable in its holotype. Omma antennatum has the subquadrate pronotum (very different from that in the species of Omma with subglobose (prothorax) and outlines of other sclerites of this species do not fit with the corresponding characteristics in the genuine species of Omma.

Ponomarenko [129] put Procarabus zitteli in Omma, but in his redescription of this species there are no reliable characteristics to support such an attribution. According to the original descriptions, Omma aberrantum has explanate elytral sides, while O. jurassicum demonstrates the narrowly explanate elytral sides; besides, O. antennarum Ponomarenko, 1997 [105] has the narrow and quadrangular prothorax (apparently with lateral carinae) and the very narrowly explanate elytral sides.

On the other hand, "Pareuryomma" ancistrodontum shows all the diagnostic characteristics to be transferred to Omma (characteristics of its head and elytra), although its pronotum has a rather large anterior orifice. Omma daxishanense was temporally placed in Omma, but at least its head with very wide frons, very prominent temples and distinct antennal grooves provide evidence to put it in Allophalerus gen. nov. rather than to another ommatine genus. Probably the same pertains to Omma brevipes, whose attribution can be clarified only after re-examination of the type of this species. Omma elongatum was initially described in the genus Carabus [126], however later Handlirsch [1] proposed to put it in a separate genus [Chalepocarabus], Crowson [131] transferred it to Omma and Ponomarenko [110] restored the genus Chalepocarabus for this unique species ("elongatus") in the subfamily Cupedinae and prepared the incorrect drawing with the prosternal process and separated procoxae in the holotype of 
Omma elongatum ([110]: 97, Figure 5). Kirejtshuk et al. [33] followed the latter opinion of Ponomarenko. The current assessment of the last two redescriptions and illustrations of this species [110,128] make it possible to find only the characteristics that can be interpreted as ommatine ones (the outlines of the body sclerites (particularly, subglobular prothorax and shape of head), also, the venation and cells of elytra in the photograph of Crowson ([131]: Pl. IV, Figure 9) fit better with those of the genuine members of Omma in comparison with the photograph in Ponomarenko ([110]: Pl. 10, Figure 7)). "Tetraphalerus" grandis better fits with Omma by the outlines of its body sclerites, than with Tetraphalerus or Allophalerus gen. nov. and, therefore, it is preliminarily put in the genus under consideration, and also "Tetraphalerus" longicollis apparently like Omma has the very narrow explanate elytral sides and prothorax clearly without lateral carinae.
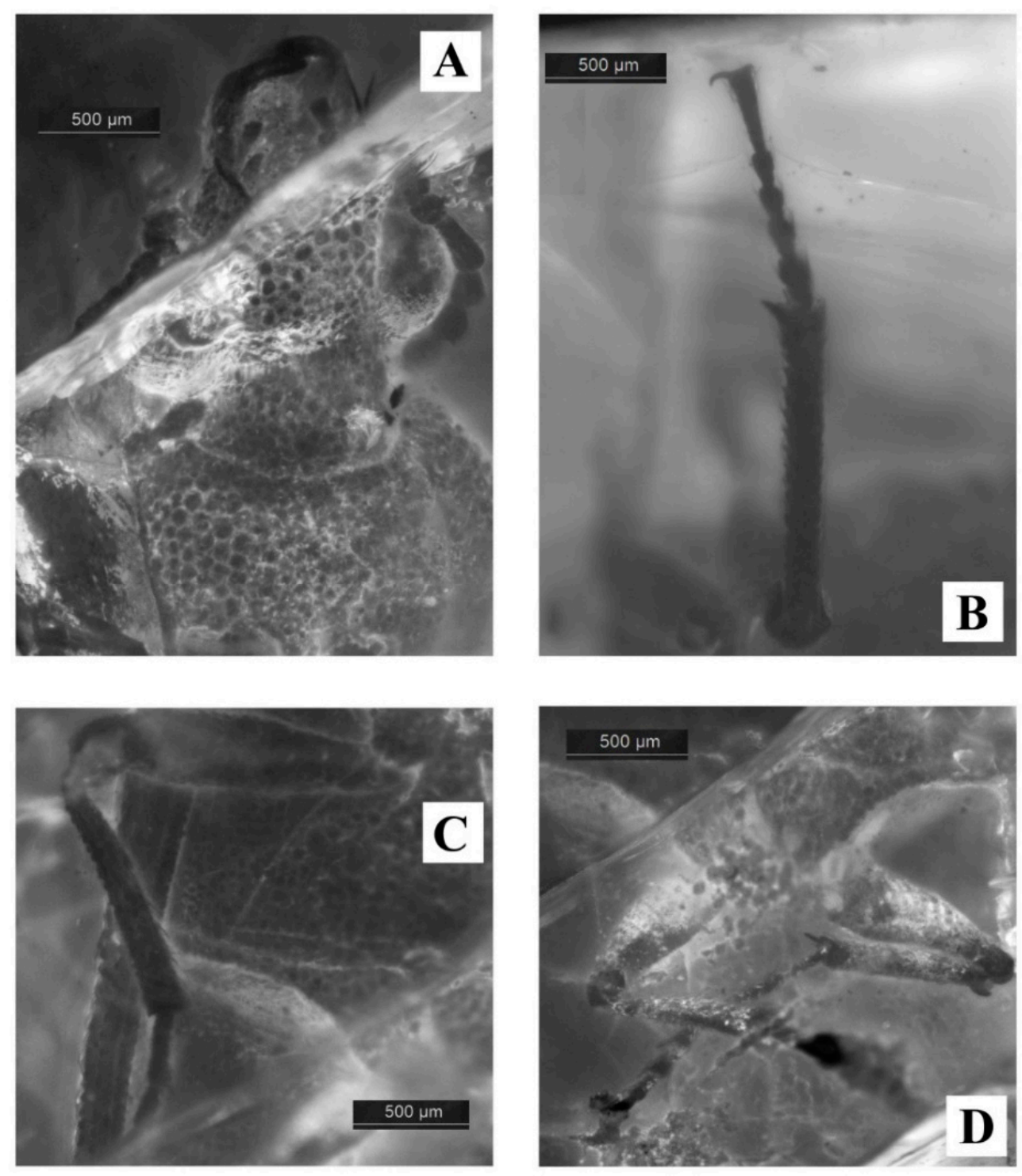

Figure 14. Ommatinae (Cupedidae): Omma janetae sp. nov., holotype ZIN Cuped 004 (Lower/Upper Cretaceous: Upper Albian/Lower Cenomanian; Myanmar, Kachin, Burmese amber); fluorescent microscopy with filter set N21: A-head and prothorax, dorsal, B-protibia and protarsus, lateral, C-intermediate leg and metacoxa, ventral, D-metacoxae and posterior legs, ventral; length of inclusion $8.6 \mathrm{~mm}$; scale for each picture provided; original. 

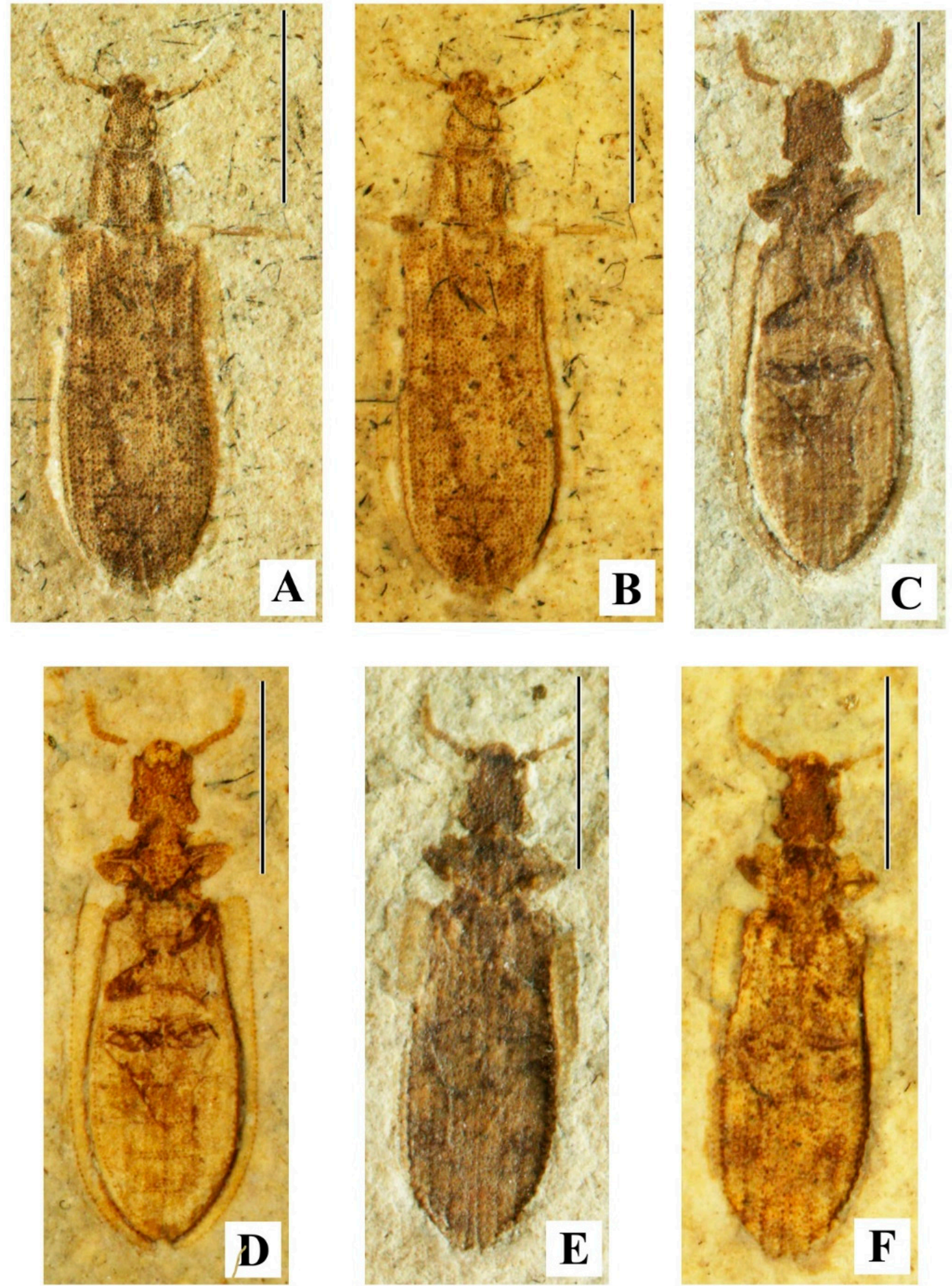

Figure 15. Ommatinae (Cupedidae): A-B-(?) Pareuryomma angustum comb. nov. [Brochocoleus], holotype CNU_C-LB2006009 (Lower Cretaceous, Lower Aptian; Liaoning, Chaomidian): A-dry and B-wettened by alcohol; length of print $14.0 \mathrm{~mm}$, scale bar $=5.3 \mathrm{~mm}$; original. C-F-Pareuryomma tylodes, holotype, CNU_C-LB2005003-1, part and CNU_C-LB2005003-2, counterpart (Lower Cretaceous, Lower Aptian Liaoning, Chaomidian); C-part, dry, D—same, wettened by alcohol; E-counterpart, dry, F-same, wettened by alcohol; length of print $6.3 \mathrm{~mm}$, scale bar $=2.5 \mathrm{~mm}$; original. 

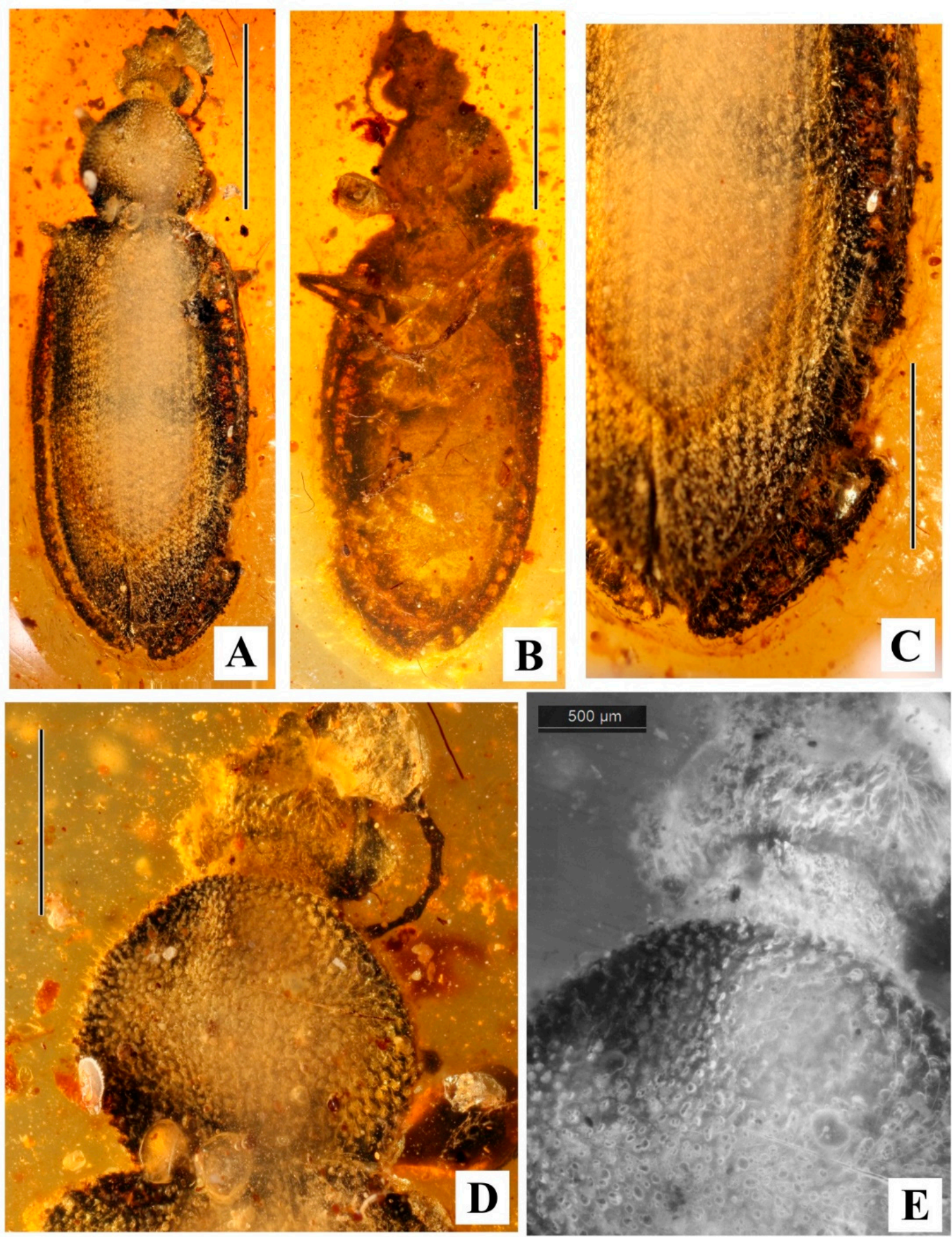

Figure 16. Ommatinae (Cupedidae): Polykius alberti sp. nov., holotype ZIN Cuped 003 (Lower/Upper Cretaceous: Upper Albian/Lower Cenomanian; Myanmar, Kachin, Burmese amber): A—beetle, dorsal, B-same, ventral, C—right elytron, dorsal; D-anterior part of body, dorsal; E-base of head and apex of pronotum, dorsal (fluorescent microscopy with filter set N21); length of inclusion $6.2 \mathrm{~mm}$, scale bar for $\mathbf{A}$ and $\mathbf{B}=2.0 \mathrm{~mm}$, scale bar for $\mathbf{C}=1.0 \mathrm{~mm}$, scale for $\mathbf{D}$ shown with mention of $\mathrm{mm}$; original. 

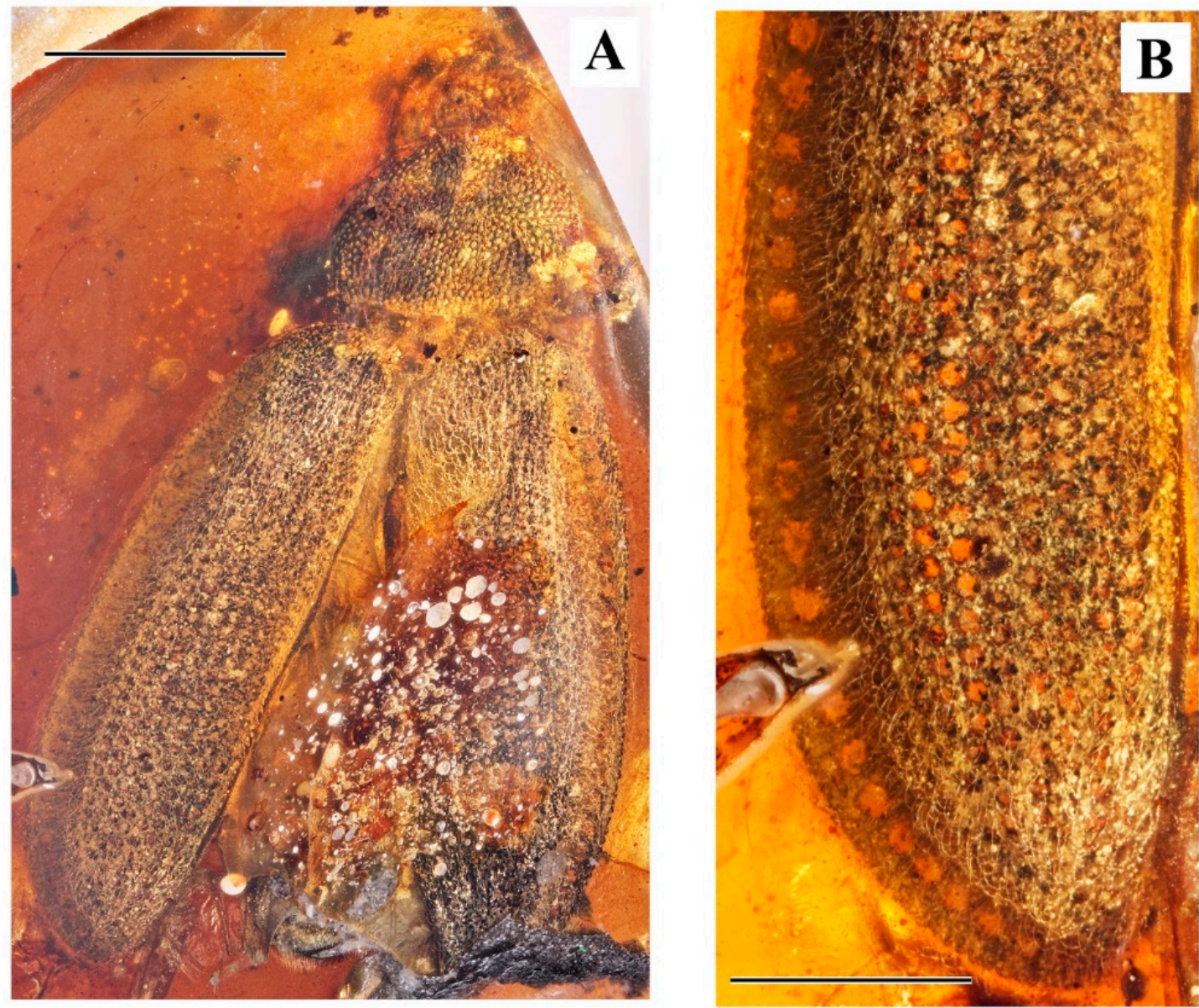

Figure 17. Ommatinae (Cupedidae): Polyakius pubescens sp. nov., holotype ZIN Cuped 003 (Lower/Upper Cretaceous: Upper Albian/Lower Cenomanian; Myanmar, Kachin, Burmese amber); A-beetle, dorsal, B-left elytron, dorsal; length of inclusion $21.0 \mathrm{~mm}$, scale bar for $\mathbf{A}=7.2 \mathrm{~mm}$ for and $\mathbf{B}=3.6 \mathrm{~mm}$; original.

The recent photograph of the holotype of Omma zitteli ([129]: Pl. VII, 1) shows the remnants of a specimen similar to Allophalerus gen. nov. rather than to any other genus, although because of a lack of reliable character for generic diagnostics it can be regarded as attributed to genus incertus. See also below the description of this new genus and comments on it.

Genus Paraodontomma Yamamoto, 2017 [133]. Type species: Paraodontomma burmitica, Yamamoto, 2017 [133], by monotypy. Two species.

Another congener: Paraodontomma szwedoi Jarzembowski, Wang, et Zheng, 2018 [134].

Myanmar: Kachin (Hukawng Valley, Burmese amber), Lower/Upper Cretaceous, Albian/Cenomanian, -99.7-94.3 Ma.

Notes. This genus is characterized by the wide, long and subparallelsided head, but with prominent large eyes and with moderate long temples, and also by the narrow pronotum with serrate lateral carinae, very wide elytra with the veins highlighted by microtuberculation and rows of large cells, explanate elytral sides with 3-4 rows of large cells, abdominal ventrites co-planar (abutting).

Genus Pareuryomma Tan, Wang, Ren et Yang, 2012 [124] (Figure 15). Type species Euryomma tylodes Tan, Ren, Shih et Ge., 2006 [125] (Figure 15C-F), by monotypy (=Euryomma Tan, Ren, Shih et Ge., 2006 [125], non Stein, 1899 [135] (Diptera)). Four species. 
Other congeners: (?) Pareuryomma angustum (Tan, Ren et Shich, 2007) [115], comb. nov. [Brochocoleus] (Figure 15A,B), Pareuryomma cardiobasis Tan, Wang, Ren et Yang, 2012 [124], Pareuryomma magnum (Tan et Ren, 2009) [121], comb. nov. [Brochocoleus],

China: Liaoning Province (Huangbanjigou, Chaomidian Village), Lower Cretaceous, Lower Aptian, -125.5-122.5 Ma; Nei Mongol (Daohugou), Middle/Upper Jurassic, Callovian/Oxfordian, $-164.7-155.7 \mathrm{Ma}$.

Notes. This genus is easily recognized by its slender body, long and subparallelsided or slightly narrowed head with moderately prominent eyes and more or less prominent temples, narrow pronotum with more or less explanate lateral carinae, elytra with the veins more or less well expressed and independently ending on Sc, large cells more or less arranged in rows on disc and moderately widely explanate sides of the elytra, and abdominal ventrites co-planar (abutting). Pareuryomma angustum comb. nov. differs from other congeners by the shorter and rather narrowing head and seems to be able to be considered as a separate genus.

The generic name Euryomma was erroneously synonymyzed with Notocupes by Kirejtshuk et al. in 2010 [11]. Later Tan et al. in 2012 [124] proposed a new name Pareuryomma for the mentioned junior homonym.

Genus Polyakius Kirejtshuk, gen. nov. (Figures 16 and 17).

Type species: Polyakius alberti sp. nov.

Another congener: Polyakius pubescens Kirejtshuk, sp. nov.

Myanmar: Kachin (Hukawng Valley, Burmese amber), Lower/Upper Cretaceous, Albian/Cenomanian, -99.7-94.3 Ma.

Note. See below the Descriptions of new taxa of the subfamily Ommatinae.

Genus Rhabdocupes Ponomarenko, 1966 [102]. Type species: Rhabdocupes longus Ponomarenko, 1966 [102], by original designation. Three species.

Other congeners: Rhabdocupes baculatus Ponomarenko, 1969 [26], Rhabdocupes minor Ponomarenko, 1966 [102].

Kyrgyzstan: Osh Region (Madygen, Madygen area and Dzhailoucho area), Middle/Upper Triassic, Ladinian/Carnian, -235.0-221.5 Ma.

Notes. This genus is characterized by the rather elongate body, very long but subtriangular head with moderately raised eyes and long temples, pronotum wide and slightly narrowing anteriorly with widely explanate lateral carinae and widely excised anterior edge, veins better expressed than other interspaces between longitudinal rows of cells and all fusing together at apex, explanate elytral sides moderately wide and with one row of cells, and abdominal ventrites overlapping.

Genus Rhopalomma Ashman, Oberprieler et Ślipiński, 2015 [136]. Type species: Rhopalomma stefaniae Ashman, Oberprieler et Ślipiński, 2015 [136], by monotypy. One species.

Australia: New South Wales, (Talbragar Fossil Fish Bed), Upper Jurassic, Tithonian, $-150.8-145.5 \mathrm{Ma}$.

Notes. This genus seems to have the prothorax arcuate (subglobose) and incarinate at the sides. Besides, it is characterized by the moderately elongate oval body, rather long and subtriangular head slightly narrowed anteriorly, elytra with well expressed veins and fused A1 and $\mathrm{Cu}$ at apex, elytral disc with moderately large cells, moderately widely explanate elytral sides which are smoothly microtuberculate. The descriptors of this genus indicated as diagnostic character "clubbed antennae" ("club of right antenna (left side of $\mathrm{CP}$ ) 3-segmented"), however their numbering of antennomeres seems to be incorrect. It is necessary also to take into consideration that some thickening of subapical antennomeres was not infrequent in Mesozoic cupedids. 
Genus Stegocoleus Jarzembowski et Wang, 2016 [137]. Type species: Stegocoleus caii Jarzembowski et Wang, 2016 [137], by monotypy. Three species.

Another congeners: Stegocoleus arkonus Tihelka, Huang et Cai, 2019 [138], Stegocoleus lawrencei Tihelka, Huang et Cai, 2019 [138].

Myanmar: Kachin (Hukawng Valley, Burmese amber), Lower/Upper Cretaceous, Albian/Cenomanian, -99.7-94.3 Ma.

Notes. This genus with its wide elytral explanate sides is similar to Brochocoleus and Jarzembowskiops gen. nov., but quite different from them in its prothorax. It is characterized by the very wide body in the elytra, moderately long and subtriangular head with slightly prominent eyes and very prominent temples, comparatively narrow to moderately wide and sharply carinate prothorax, elytral veins not expressed, more or less irregular cells of the elytral disc and explanate elytral sides with four or more rows of very large cells (more or less visible at least at the elytral base), and abdominal ventrites apparently co-planar (abutting).

Genus Tetraphalerites Crowson, 1962 [131]. Type species: Tetraphalerites oligocenicus Crowson, 1962 [131], by monotypy. One species.

United Kingdom: England (Isle of Wight, Bembridge Marls), Upper Eocene, Priabonian, -37.2-33.9 Ma.

Notes. According to the described holotype of the type species, this genus is represented in the positive and negative print and counterprint only showing the metatorax and abdomen with the most part of the elytra and characterized by an elongate oval body with the elytra finely and diffusely punctured as on disc as on explanate sides, very weakly traced veins and co-planar (abutting) abdominal ventrites. To clarify other characteristics of this genus it is necessary to find any Cenozoic congener with a better preservation.

Genus Tetraphalerus Waterhouse, 1901 [104]. Type species Tetraphalerus wagneri Waterhouse, 1901 [104], recent. Five fossil species somewhat similar to the modern ones.

Probable congeners: (?) Tetraphalerus brevis Ponomarenko, 1964 [103], (?) Tetraphalerus collaris Ponomarenko, 1997 [105], (?) Tetraphalerus glabratus Ponomarenko 1997 [105], (?) Tetraphalerus mongolicus Ponomarenko, 1986 [139], (?) Tetraphalerus notatus Ponomarenko, 1997 [105].

Kazakhstan: Chimkent Region (Mikhailovka); Upper Jurassic, Callovian/Oxfordian, -164.7-155.7 Ma.

Mongolia: Gobi-Altai Aimag (Gurvan-Ereny-Nuruu), Lower Cretaceous, Aptian, -125.5-112.6 Ma; Bayan-Khongor Aimag (Bahar or Bakhar), Middle Jurassic, Bajocian/Bathonian, -171.6-164.7 Ma; Bayan-Khongor Aimag (Bon Tsagaan); Lower Cretaceous, Aptian, -125.5-112.6 Ma.

Notes. If the characteristics used in this publication for other generic diagnoses of fossils are applied to the modern species, this genus can be characterized by the elongate body, elongate and slightly anteriorly narrowed head with small eyes or eyes covered with processes of the frons, very long and prominent temples, narrow prothorax without sharp lateral carinae (modern species of Tetraphalerus have lateral carinae on the prothorax, although they are obscured by the microtubercles), elytra with more or less expressed veins (A1 and $\mathrm{Cu}$ fused at apex or independently ending on $\mathrm{Sc}$ ), explanate elytral sides which are very narrow and without cells, and abdominal ventrites co-planar (abutting). At the same time, it is scarcely reasonable to expect fossil relatives of the modern South American species of Tetraphalerus sensu stricto to be found among Mesozoic cupedids and most species which were formerly put in this genus are here considered in the composition of Allophalerus gen. nov. (see below the Description of the latter genus). Some Mesozoic species are still temporally remain in this genus with a question mark and their attribution needs to be checked by a further re-examination of type material.

According to the original description, (?) Tetraphalerus brevis has the pronotum shorter than head, flattened and with sharp lateral edges ([103]: 53: “переднеспинка короче головы, поперечная, ее боковой край уплощенный и острый") and, on the other hand, a rather narrow epipleuron 
(“эпипплевра довольно узкая"), although its photograph makes it possible to suppose that prothorax seems to have rounded sides ([103]: Pl.VI, 3) but not subquadrangular as drawn in the original description ([103]: 52, 2b). (?) Tetraphalerus collaris has the characteristics of the modern species in its head, its pronotum and elytral base fit better with the modern species than those in other Mesozoic species. However in order to be sure of its attribution it is necessary to study similar fossil representative with a better preservation. (?) Tetraphalerus glabratus somewhat corresponds to Tetraphalerites oligocenicus, but in the original description it was mentioned that its elytral "cells" (not punctures) are scarcely observable. The holotype of (?) Tetraphalerus mongolicus has its body outlines like those in other "? Tetraphalerus" species, but it shows no peculiar important character for a reliable generic diagnostics, although the descriptor compared it with "T. verrucosus" [139]. The type series of (?) Tetraphalerus notatus includes different imprints. The descriptor did not indicate the holotype in the list of the examined specimens, but in the caption to "Figure 6" there is mentioned as "the holotype" the number which was not included in the list of the examined specimens. The description and illustrations of (?) Tetraphalerus notatus contain characteristics from different imprints which do not give any reason to assign this species to any precise genus. Thus, this species name should be reasonably considered without generic attribution.

Genus Zygadenia Handlirsch, 1906 [1] (Figures 18 and 19). Type species: Curculionites tuberculatus Giebel, 1856 [140], by monotypy (=Curculionites Giebel, 1856 [140], non Heer, 1847 [141], type species: Curculionites tuberculatus Giebel, 1856 [140]; Kakozelia Handlirsch, 1906 [1], type species: Camptodonthus angliae Giebel, 1856 [140], by monotypy; Notocupes Ponomarenko, 1964 [103], type species: Notocupes picturatus Ponomarenko, 1964 [103], by monotypy; Sinocupes Lin, 1976 [142], type species: Sinocupes validus Lin, 1976 [142], by monotypy; Chengdecupes Hong 1983 [143], type species: Chengdecupes jurassicus Hong 1983 [143], by monotypy; Conexicoxa Lin, 1986 [144], type species: Conexicoxa homora Lin, 1986 [144], by monotypy; Forticupes Hong et Wang, 1990 [145], type species: Forticupes laiyangensis Hong et Wang, 1990 [145], by monotypy; Picticupes Hong et Wang, 1990 [145], type species: Picticupes tuanwangensis Hong et Wang, 1990 [145], by monotypy; Amblomma Tan, Ren et Liu, 2005 [146], type species: Amblomma psilata Tan, Ren et Liu, 2005 [146], by original designation; Ovatocupes Tan et Ren, 2006 [147], type species: Ovatocupes alienus Tan et Ren, 2006 [147], by monotypy). 71 Species.

Congeners: Zygadenia aliena (Tan et Ren, 2006) [147], comb. nov. [Ovatocupes] (Figure 18A,B), Zygadenia angliae (Giebel, 1856) [140] [Camptodonthus, Kakozelia], Zygadenia baojiatunensis (Hong 1992) [148], comb. nov. [Chengdecupes], Zygadenia brachycephala (Ponomarenko, 1994) [111], comb. nov. [Notocupes], Zygadenia caduca (Ponomarenko, 1969) [26], comb. nov. [Notocupes], Zygadenia caudata (Ponomarenko, 1966) [121], comb. nov. [Notocupes], Zygadenia cellulosa (Ponomarenko, 1969) [26], comb. nov. [Notocupes], Zygadenia crassa (Ponomarenko, 1969) [26], comb. nov. [Notocupes], Zygadenia cyclodontus (Tan, Ren, Shih et Ge, 2006) [125], comb. nov. [Amblomma, Notocupes], Zygadenia diazromerali Soriano et Declós, 2006 [116], Zygadenia dischdes (Zhang, 1986) [149], comb. nov. [Notocupes], Notocupes dundulaensis (Ponomarenko, 1994) [111], comb. nov. [Notocupes], Zygadenia elegans (Ponomarenko, 1994) [111], comb. nov. [Notocupes], Zygadenia epicharis (Tan, Ren et Liu, 2005) [147], comb. nov. [Amblomma, Notocupes], Zygadenia eumeura (Tan, Ren et Liu, 2005) [147], comb. nov. [Amblomma, Notocupes], Zygadenia excellens (Ponomarenko, 1966) [102], comb. nov. [Notocupes], Zygadenia exigua (Ponomarenko, 1994) [111], comb. nov. [Notocupes], Zygadenia foersteri (Ponomarenko, 1971) [133], comb. nov. (=reticulatus Ponomarenko, 1968 [107], non reticulatus Oppenheim, 1888 [128]) [Procarabus, Notocupes], Zygadenia floodpagei Jarzembowski, Wang, Zhang et Fang, 2015 [150], Zygadenia giebeli Ponomarenko, 2014 [151], Zygadenia handlirschi Ponomarenko, 2014 [151], Zygadenia homora (Lin, 1986) [144], comb. nov. [Conexicoxa, Notocupes], Zygadenia issykkulensis (Ponomarenko, 1969) [26], comb. nov. [Notocupes], Zygadenia jurassica (Hong 1983) [143], comb. nov. [Chengdecupes], Zygadenia kezuoensis (Hong 1987) [152], comb. nov. [Chengdecupes], Zygadenia khasurtuiensis (Strelnikova, 2019) [153], comb. nov. [Notocupes], Zygadenia khetanensis (Ponomarenko, 1993) [108], comb. nov. [Notocupes], Zygadenia kirghizica (Ponomarenko, 1969) [26], comb. nov. [Notocupes], Zygadenia laeta (Lin, 1976) [142], [Tetraphalerus], Zygadenia laiyangensis (Hong et Wang, 1990) [145], comb. nov. [Forticupes, 
Notocupes], (?) Zygadenia lapidaria (Ponomarenko, 1968) [107], comb. nov. [Notocupes], Zygadenia laticella (Ponomarenko, 1969) [26], comb. nov. [Notocupes], Zygadenia lata (Ponomarenko, 1969) [26], comb. nov. [Notocupes], Zygadenia lenta (Ren, Lu, Guo et Ji, 1995) [96], comb. nov. [Tetraphalerus], Zygadenia lini (Ponomarenko, Yan, Wang et Zhang, 2012) [96], comb. nov. [Notocupes], Zygadenia liui Jarzembowski, Wang, Zhang et Fang, 2015 [150], Zygadenia longicollis (Ponomarenko, 1994) [111], comb. nov. [Notocupes], Zygadenia longicoxa Soriano et Declós, 2006 [117], Zygadenia ludongensis (Wang et Liu, 1996) [154], comb. nov. [Notocupes], Zygadenia martinae Jarzembowski, Wang, Zhang et Fang, 2015 [150], Zygadenia martinclosas Soriano et Declós, 2006 [116], Zygadenia minuscula (Tan, Ren, Shih et Ge, 2006) [155], comb. nov. [Amblomma, Notocupes] (Figure 18C-F), Zygadenia mongolica (Ponomarenko, 1994) [111], comb. nov. [Notocupes], Zygadenia nigrimonticola (Ponomarenko, 1968) [107], comb. nov. [Notocupes], Zygadenia oculata Soriano et Declós, 2006 [116], Zygadenia oxypyga (Ponomarenko, 1969) [26], comb. nov. [Notocupes], Zygadenia patula (Ponomarenko, 1985) [156], comb. nov. [Notocupes], Zygadenia pingi (Ponomarenko et Ren, 2010) [157], comb. nov. [Notocupes], Zygadenia porrecta (Tan, Ren, Shih et Ge, 2006) [155], comb. nov. [Amblomma, Notocupes] (Figure 19A-C), Zygadenia protensa (Tan, Ren, Shih at Ge, 2006) [155], comb. nov. [Amblomma, Notocupes] (Figure 19D,E), Zygodenia psilata (Tan, Ren et Liu, 2005) [146], comb. nov. [Amblomma, Notocupes], (?) Zygadenia pulchra Ponomarenko, 1968 [107], comb. nov. [Notocupes], Zygadenia reticulata (Oppenheim, 1888) [128], comb. nov. [Procarabus, Notocupes], Notocupes rostrata (Ponomarenko, 1969) [26], comb. nov. [Notocupes], Zygadenia rudis (Tan, Ren et Liu, 2005) [146], comb. nov. [Amblomma, Notocupes], (?) Zygadenia semen Ponomarenko, 2000 [73], Zygadenia shiluoensis (Hong 1984) [158], comb. nov. [Chengdecupes], (?) Zygadenia sibirica Ponomarenko, 2000 [73], Zygadenia simpsoni Jarzembowski, Wang, Zhang et Fang, 2015 [150], Zygadenia siniestri Jarzembowski, Wang, Zhang et Fang, 2015 [150], (?) Zygadenia sinitzae Ponomarenko, 2000 [73], Zygadenia sogutensis (Ponomarenko, 1969) [26], comb. nov. [Notocupes], Zygadenia stabilis (Tan, Ren et Liu, 2005) [146], comb. nov. [Amblomma, Notocupes], Zygadenia tenuis (Ponomarenko, 1969) [26], comb. nov. [Notocupes], Zygadenia tripartita (Oppenheim, 1888) [128], comb. nov. [Procarabus, Notocupes], Zygadenia tuanwangensis (Hong et Wang, 1990) [145], comb. nov. [Picticupes, Notocupes], Zygadenia tuberculata (Giebel, 1856) [140] [Curculionites, Notocupes], Zygadenia valida (Lin, 1976) [142], comb. nov. [Sinocupes, Notocupes], Zygadenia viridis Jarzembowski, Wang, Zhang et Fang, 2015 [150], Zygadenia vitimensis (Ponomarenko, 1966) [109], comb. nov. [Notocupes], Zygadenia westraliensis (Riek, 1968) [159] [Mesothoris].

United Kingdom: England (Smokejacks Brickworks and Beare Green Brickworks), Lower Cretaceous, Barremian, -130.0-125.5 Ma; England (Durlston Bay), Lower Cretaceous, Upper Berriasian, -145.5-140.2 Ma; England (Dinton, Vale of Wardour, Middle Purbeck), Lower Cretaceous, Middle Berriasian, -145.5-140.2 Ma; Surrey, (Clockhouse Brickworks), Lower Cretaceous, Valanginian/Hauterivian, -136.4-130.0 Ma.

Spain: Cuenca Province, (Las Hoyas), Lower Cretaceous, Upper Barremian, -130.0-125.5 Ma; Sierra del Montsec (La Cabrua outcrop), Lower Cretaceous, Early/Lower Barremian, -130.0-125.5 Ma.

Germany: Bavaria (Solnhofen); Upper Jurassic, Tithonian, $-150.8-145.5 \mathrm{Ma}$.

Russia: Tyumen' Region (Layma); Middle Jurassic, Callovian, -164.7-161.2 Ma; Chita Region (Semen Creek); Lower Cretaceous, Early/Lower Aptian, -125.5-122.5 Ma; Chita Region (Unda); Upper Jurassic, Tithonian, -150.8-145.5 Ma; Buryatia (Khasurty); Lower Cretaceous, Aptian, -125.5-112.6 Ma; Buryatia (Baissa); Lower Cretaceous, Aptian, -125.5-112.6 Ma; Khabarovsk Krai (Khetana River); Upper Cretaceous, Cenomanian/Turonian, -94.3-89.3 Ma.

Kazakhstan: Chimkent Region (Mikhailovka); Upper Jurassic, Callovian/Oxfordian, -164.7-155.7 Ma; Kzyl-Ordinskaya Region (Kzyl-Zhar or Kzyl-Dzhar); Upper Cretaceous, Turonian, -(94.3-89.3 Ma; Kysyltam (Ketmen Mountains); Middle/Upper Triassic, Ladinian/Carnian, $-235.0-221.5$ Ma. 


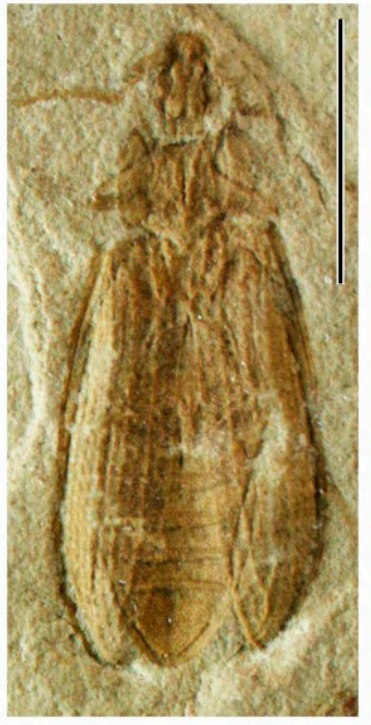

A

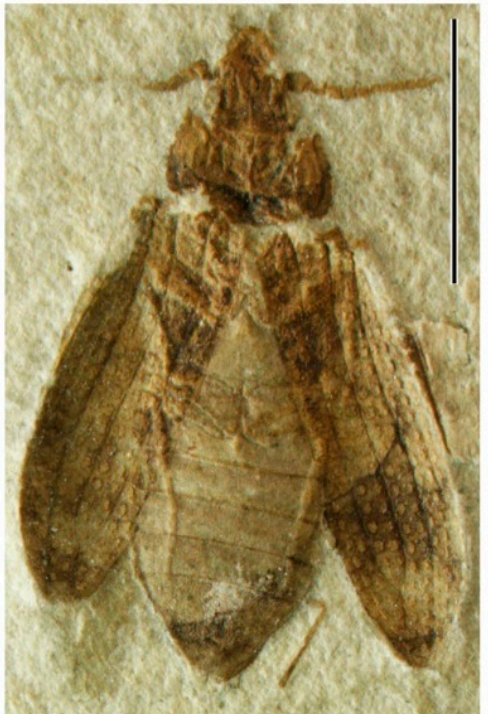

C

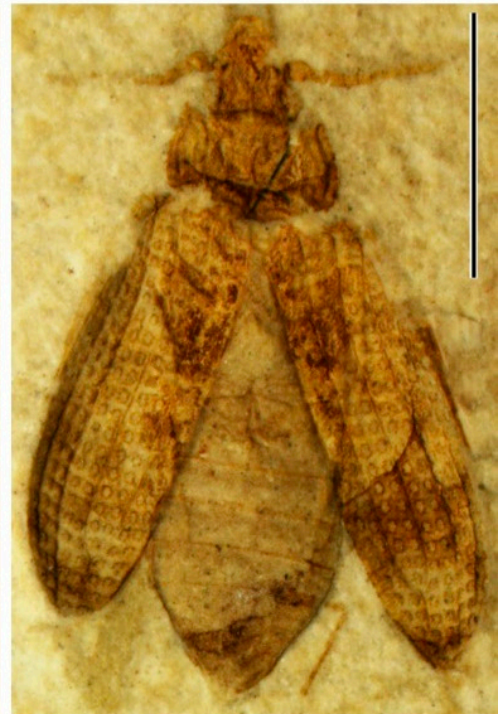

D

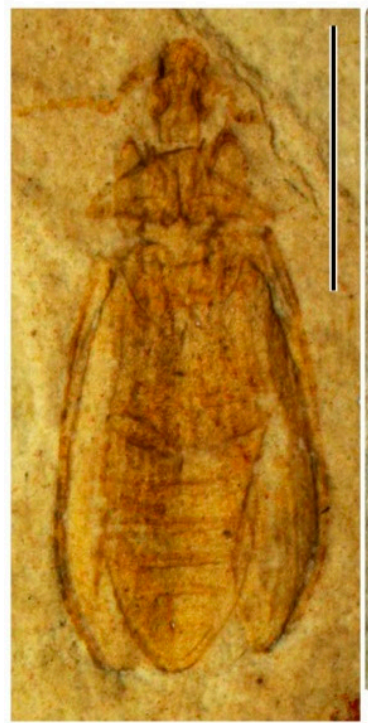

B

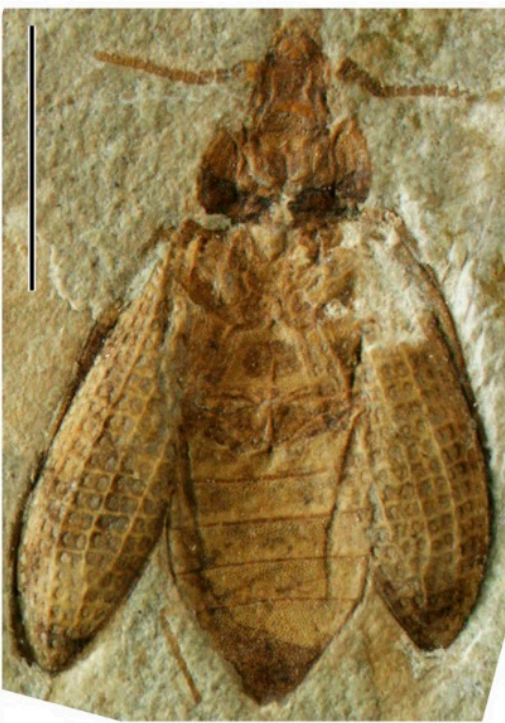

$\mathbf{E}$

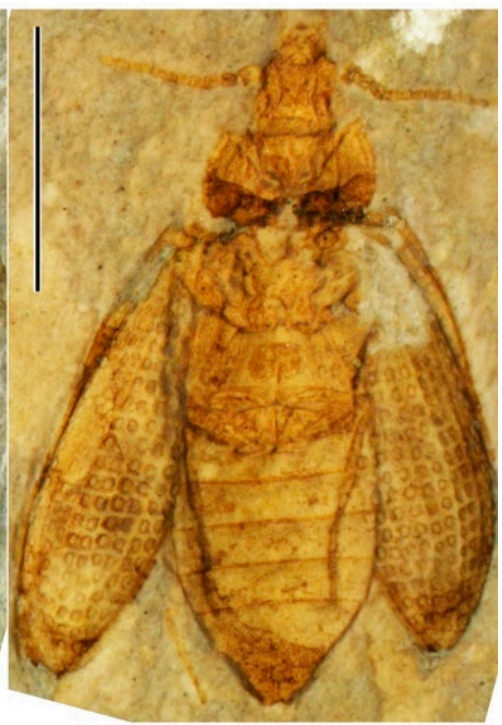

$\mathbf{F}$

Figure 18. Ommatinae (Cupedidae): A-B Zygadenia aliena comb. nov. [Ovatocupes], holotype CNU-C-LBC2005001(Lower Cretaceous, Lower Aptian; Liaoning, Chaomidian): A-dry, B-wettened by alcohol; length of print $9.5 \mathrm{~mm}$, scale bar $=4.0 \mathrm{~mm}$; original. $\mathbf{C}-\mathbf{F}-$ Zygadenia minuscula comb. nov. [Amblomma, Notocupes], holotype, CNU-C-LB2005005-1, part and CNU-C-LB2005005-2, counterpart (Lower Cretaceous, Lower Aptian Liaoning, Chaomidian); C—part, dry, D—same, wettened by alcohol; E-counterpart, dry, F-same, wettened by alcohol; length of print $10.0 \mathrm{~mm}$, scale bar $=4.0 \mathrm{~mm}$; original.

Kyrgyzstan: Osh Region (Madygen, Dzhailoucho area); Middle/Upper Triassic, Ladinian/Carnian, -235.0-221.5 Ma; Osh Region (Kyzyl-Kiya); Lower Jurassic, Pliensbachian, -189.6-183.0 Ma; Tonskiy (Ak-Bulak-Say, Sogjuta, Issyk-Kul); Upper Triassic/Lower Jurassic, Rhaetanian/Hettangian, -201.6-189.6 Ma.

Tajikistan (Shurab II, Ditch); Lower Jurassic, Pliensbachian, -189.6-183.0 Ma.

Mongolia: Bayan-Khongor Aimag (Shar-Tolgoy); Lower Cretaceosu, Aptian, -125.5-112.6 Ma; Bayan-Khongor Aimag (Bon Tsagaan); Lower Cretaceous, Aptian, -125.5-112.6 Ma; Bayan-Khongor Aimag (Bahar or Bakhar); Middle Jurassic, Bajocian/Bathonian -171.6-164.7 Ma; Bayan-Khongor 
Aimag (Khurilt and Bon Tsagaan); LowerCretaceous, Aptian, -125.45-112.6 Ma; Gobi-Altay Aimag (Shar-Teg); Upper Jurassic, Tithonian, -150.8-145.5 Ma; Bayan-Khongor (Bakhar); Middele Jurassic, Bajocian/Bathonian, -171.6-164.7 Ma.

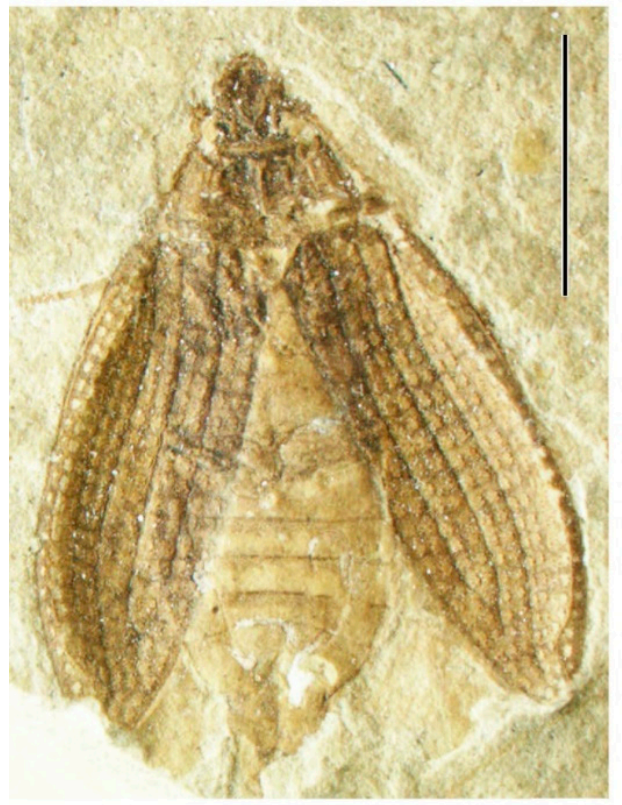

A

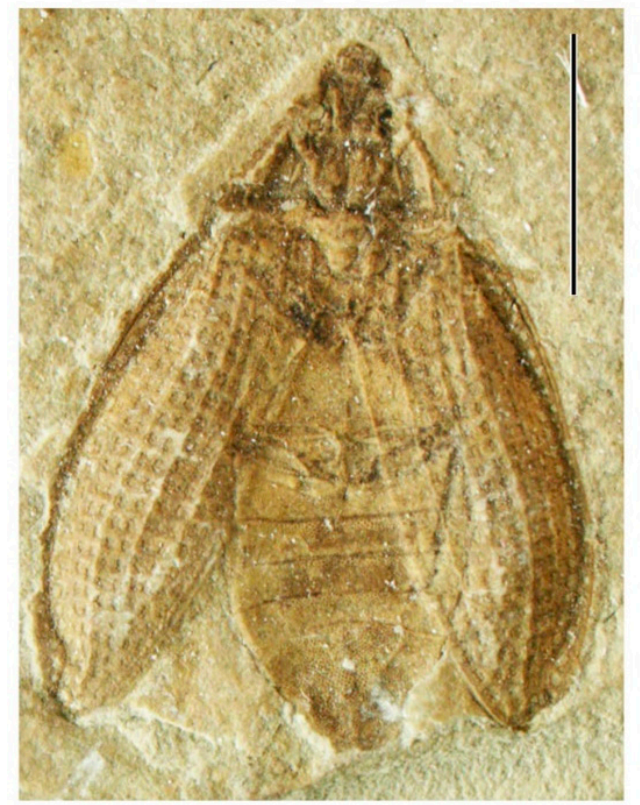

C

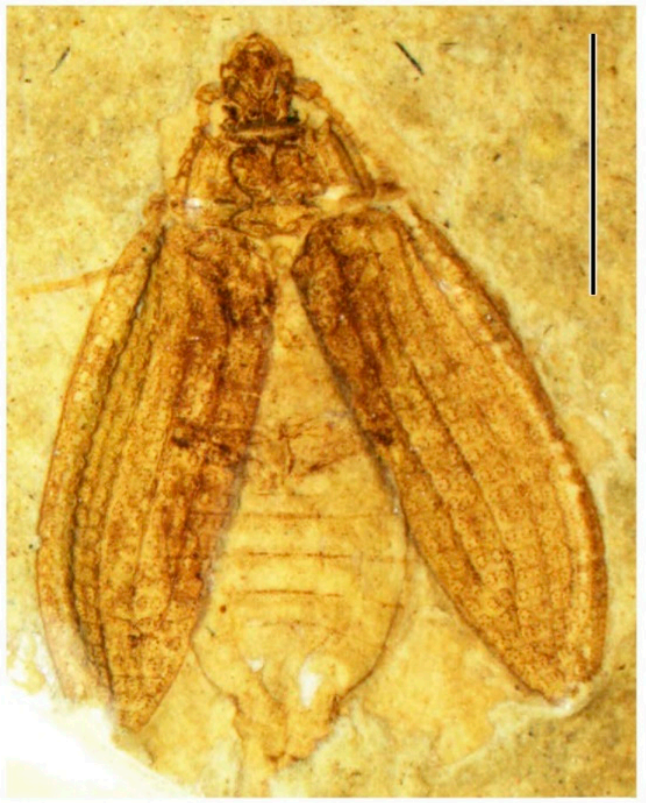

B

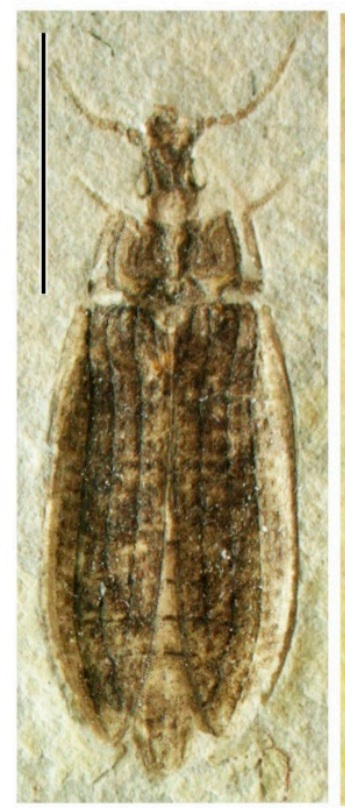

D

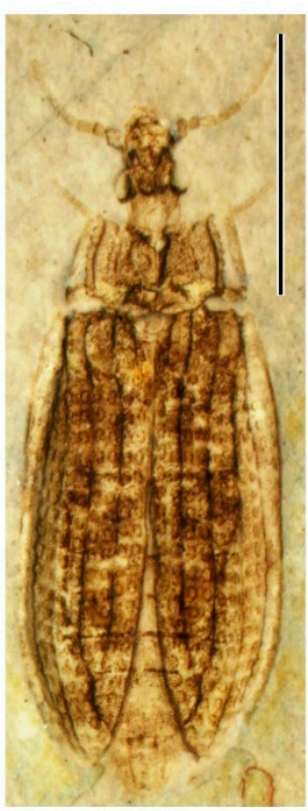

E

Figure 19. Ommatinae (Cupedidae): A-C-Zygadenia porrecta comb. nov. [Amblomma, Notocupes], holotype, CNU-C-LBC2005006-1, part and CNU-C-LBC2005006-2, counterpart (Lower Cretaceous, Lower Aptian; Liaoning, Chaomidian): A-part, dry; B-same, wettened by alcohol; C-counterpart, dry; length of print $12.0 \mathrm{~mm}$, scale bar $=4.3 \mathrm{~mm}$; original. D-E-Zygadenia protensa comb. nov. [Amblomma, Notocupes], holotype, CNU-C-LB2005008-1, part (Lower Cretaceous, Lower Aptian Liaoning, Chaomidian): D—dry; E-wettened by alcohol; length of print $10.0 \mathrm{~mm}$, scale bar $=3.7 \mathrm{~mm}$; original. 
China: Liaoning Province (Huangbanjigou, Chaomidian Village); Lower Cretaceous, Lower Aptian, -125.5-122.5 Ma; Liaoning Province (Changbodianzi, Shangyuan); Lower Cretaceous, Barremian, -130.0-125.5 Ma; Liaoning Province (Xiwan village, Meileyingzi, Kezuo); Lower Cretaceous, Aptian, -125.5-112.6 Ma; Nei Mongol (Xisanjia), Lower Cretaceous, Lower Aptian, -125.5-122.5 Ma; Nei Mongol (Daohugou); Middle/Upper Jurassic, Callovian/Oxfordian, -164.7-155.7 Ma; Shandong (Huangyadi, Muyudianxiang, Laiyang City); Lower Cretaceous, Aptian, -125.5-112.6 Ma; Hunan (Meitian, Yuanzhu, Lanshan County); Upper Triassic/Lower Jurassic, Rhaetian/Hettangian, -201.6-196.5 Ma; Hebei (Zhouyingzi, Luoping County); Middle/Upper Jurassic, Callovian/Oxfordian, -164.7-155.7 Ma; Hebei (Xiaofanzhangzi, Chengde City); Middle/Upper Jurassic, Callovian/Oxfordian, -164.7-155.7 Ma;Hunan (Guanyintan, Qiyang County); Lower/Middle Jurassic, Toarcian/Aalenian, -183.0-171.6 Ma; Zhejiang Province (Laozhu, Lishui); Lower Cretaceous, Early/Lower Aptian, -125.5-122.5 Ma; Jilin (Luozigou, Wangqing County); Lower Cretaceous, Aptian, -125.5-112.6 Ma; Jilin Province (Baojiatun, Jiaohe County); Lower Cretaceous, Aptian, -125.5-112.6 Ma; Shanxi Province (Mengjiachang, Shilou County); Middle Triassic, Ladinian, -242.0-235.0 Ma.

Democratic People's Republic of Korea: North Pyongan Province (Sinuiju City Paektodong, 97 DPRK, Lower Cretaceous, Sinuiju Formation (Won et al., 2019).

Australia, Western Australia (Mintaja 1 outcrop, Hill River), Lower Jurassic, Toarcian -183.0-175.6 Ma; Western Australia (Hill River, grid reference), Lower Jurassic, Toarcian $-183.0-175.6 \mathrm{Ma}$.

Notes. This genus is diagnosed based on the following characteristics: head elongate, with longitudinal grooves and slightly narrowing anteriorly (frons before eyes more or less long); antennae short and scape usually longest among antennomeres; pronotum wide and distinctly carinate at sides, its anterior and posterior angles with distinct top; elytra with explanate sides bearing one long row of large cells along Sc, A1 and $\mathrm{Cu}$ fused before apex and common vein ending on suture, intervenal stripes with two rows of cells. The group with this diagnosis is most abundant and rather variable in Mesozoic deposits and, therefore, it acquired so many synonyms. However, its variability is so great that it is a reasonable to expect that a detailed revision of this group in the current sense will make it possible to find some groups of close relatives with expressed hiatus, for which some clear diagnostic characteristics can be found to propose new generic taxa or restore some names treated here as synonyms. In particular, the Australian members of Zygadenia (Z. martinae and Z. westraliensis) have peculiar cells of the elytra and seem to be enough separated from Eurasian ones [160] to propose for them a new palaeoendemic Australian genus.

The junior homonym Curculionites Giebel, 1856 [140], non Heer, 1847 [141] was proposed for the group with four species proposed together with the genus (syrichtus, westwoodi, tuberculatus and marginatus) and, Curculionites tuberculatus Giebel, 1856, which has enough the more or less distinct characteristics for a reliable taxonomic interpretation, was chosen by Handlirsch as the type species of Zygadenia. The same was made for the generic name Procarabus including three species names proposed together with the generic one (reticulatus, tripartitus and zitteli), which were put in Omma (zitteli) and Notocupes (reticulatus, tripartitus) [129].

The generic name Forticupes is based on the description of a badly preserved specimen (Forticupes laiyangensis) which was put in the subfamily Ommatinae, although the characteristics making such supposition really true are not clearly expressed (nevertheless the elytral apex looks ommatine rather than cupedine). The name Conexicoxa was proposed for the description of a species (Conexicoxa homora) interpreted as a member of Trachypachidae and represented only by the underside of the metathorax with posterior legs and abdomen. It was transferred at first to Zygadenia [110] and later automatically to the restored Notocupes [96], however the imprint of the holotype of Conexicoxa homora can scarcely be considered as Notocupes or Zygadenia. The synonymization of these names is also here recognized as proposed by Ponomarenko et al. [96].

The genus Chengdecupes with the type species Chengdecupes jurassicus was preliminarily synonymized with Notocupes by Kirejtshuk et al. [11] and later it was also assigned to Ommatinae [33]. 
To this genus after its proposal other three members were added by Hong: Chengdecupes baojiatunensis, C. kezuoense and C. shiluoense. The additional estimation of the characteristics of the above mentioned species made it possible to specify some details visible in the photograph of the holotypes of all members of this genus and to support the previous synonymization of this name with Zygadenia by Kirejtshuk et al. [11], although four species described as members of Chengdecupes could belong to different generic groups.

Zygadenia laeta comb. nov. [Tetraphalerus] has the structure of pronotum and elytra certainly characteristic of Notocupes but not Tetraphalerus. Both species described as "Notocupes" undatabdominus Lin, 1980 [161] and "N." (?) multituberatus Lin, 1980 [161] (China: Zhejiang (Laozhu, Lishui); Lower Cretaceous, Lower Aptian, -125.5-122.5 Ma) have no characterictics making it possible to assign them to archostematans and, therefore, these two species are regarded without subordinal, family and generic attribution (incertae sedis). Both species (?) Zygadenia semen and (?) Z. sibirica were described after study of the underside sclerites of pterothorax, abdomen and elytral epipleura as members of Zygadenia. However, in the original descriptions of both these species a very narrow epipleuron is pointed out, but there is no mention any diagnostic character. Therefore, the attribution of these species is also used here with question mark. In other cases the question mark was put if any described member of Zygadenia (=Notocupes) has no characteristics for a reliable generic diagnostics.

Nevertheless, the large taxon Zygadenia in sense here accepted, on the one hand, is rather variable and, on the other hand, includes some members, which seem to be enough different, to consider them as a member of another genus. In particular, the drawing of the distal part of the elytron designated as the holotype of Zygadenia tuberculata (type species of the genus) [1] shows the obscure fusion A1 and $\mathrm{CuA}$ and strongly approached to the elytral apex. The description of the type species of Notocupes (N. picturalis) [103] was described with mention on the elytral venation in the text and with unclear picture and drawing of the holotype. Besides, Ponomarenko described Zygadenia sinitzae [73] with completely different elytral venation (according to the drawing), and some congeners were described without information on elytral venation at all. Finally, Ponomarenko gave a general scheme of the elytral venation of the genus Zygadenia [110] which is rather different different from that in known congeners. Thus, the many species of this taxon need to be revised to clarify their attribution.

\section{New Taxa of the Subfamily Ommatinae}

Genus Allophalerus Kirejtshuk, gen. nov.

urn:1sid:zoobank.org:act:8F8C2DE9-86B4-4FE6-9BE2-058BF2729DD5

Type species: Tetraphalerus aphaleratus Ponomarenko, 1969 [26]; fossil; Lower Jurassic, Pliensbachian (Pliensbachian/Toarcian), Osh Region, Kyzyl-Kiya.

Composition: In addition to the type species (Allophalerus aphaleratus comb. nov.), also Allophalerus antiquus comb. nov. [Tetraphalerus], Allophalerus bontsaganensis comb. nov. [Tetraphalerus], (?) Allophalerus incertus comb. nov. [Tetraphalerus], Allophalerus latus comb. nov. [Tetraphalerus] (Figure 4A,B), (?) Allophalerus maximus comb. nov. [Tetraphalerus], Allophalerus okhotensis comb. nov. [Tetraphalerus], Allophalerus verrucosus comb. nov. [Tetraphalerus]. See more details above.

Diagnosis. Body elongate; head long and usually subparallelsided, eyes located at middle level, temples very long; prothorax rather narrow with sides explanate and distinctly carinate; veins more or less expressed (including A2), subparallelly terminated on Sc along lateral elytral edge; cells variable but usually expressed; explanate elytral sides moderately to rather wide and with diffuse microtubercles or small punctures; abdominal ventrites co-planar (abutting). 

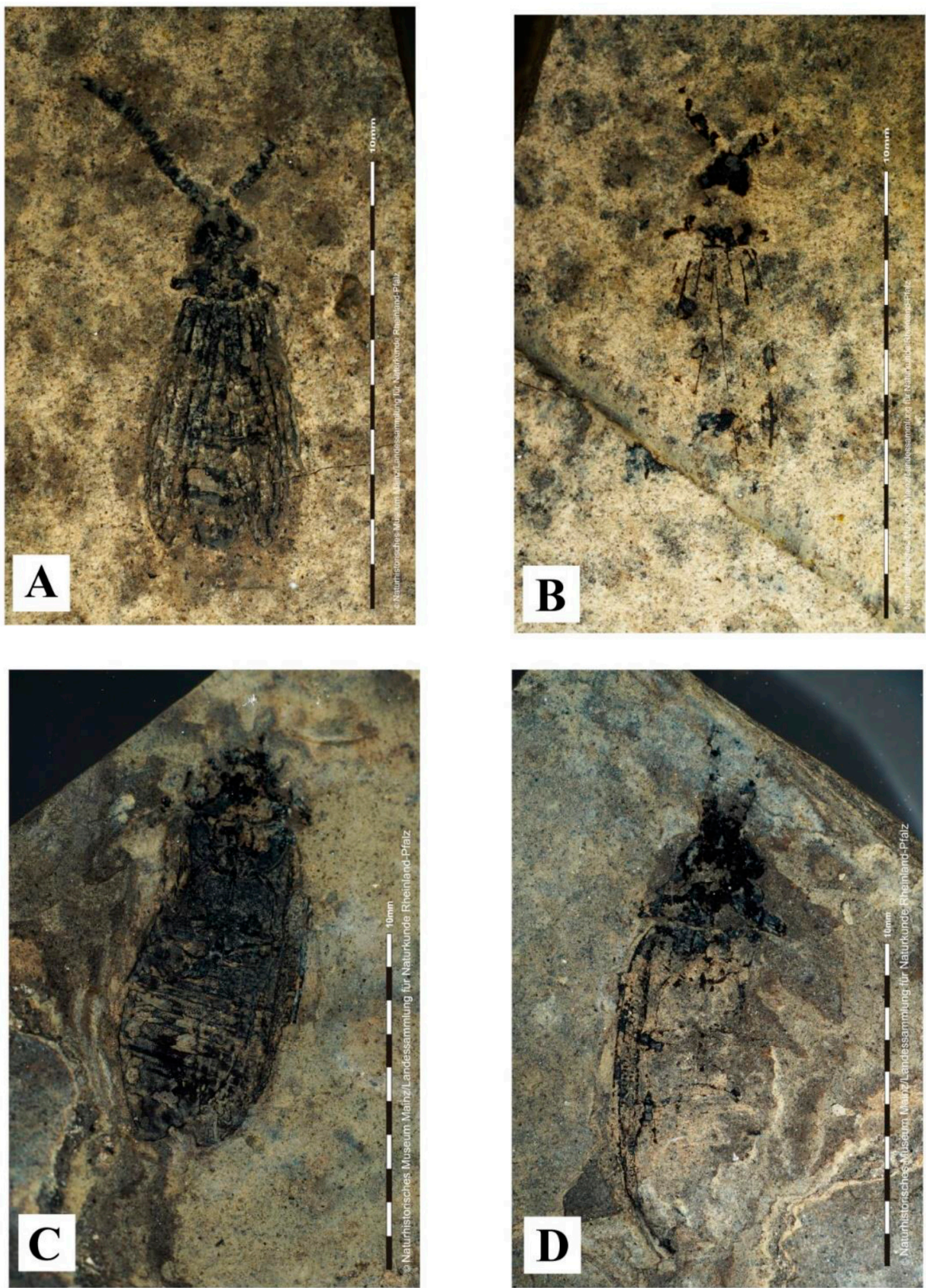

Figure 20. Cupedinae (Cupedidae). species of Cupes from Eckfeld (Palaeogene, Eocene, Lutetian; Eifel, Eckfeld Maar). A-B-Cupes golovatchi sp. nov., holotype, PE 200001146 a (LNNR), part (A) and PE 200001146-b (LNNR), counterpart (B). C-D_Cupes legalovi sp. nov., holotype, PE 1992000522-a (LNNR), part and PE 1992000522-b (LNNR), counterpart. Scale for each picture provided. Original.

Notes. Usually this genus is associated with Tetraphalerus, although the species of this genus in the modern fauna are distributed in South America (Tetraphalerus bruchi Heller, 1913 [162] and 
T. wagneri [104] and at the moment it is scarcely possible to explain their phyletic links with Asian Mesozoic species. Moreover, the modern species of the mentioned group sharing some external similarity with some extinct Mesozoic ones differ from the latter groups in the lateral elytral sides not being explanate or very narrowly explanate, prothorax without sharp lateral carinae and scutellum widened apically (although the prothorax of the modern representatives slightly dorsoventrally compressed). The two mentioned recent species of Tetraphalerus have different elytral venation and it makes it possible to suppose that their phylogenetic separation happened rather long ago. It is here supposed that a considerable similarity of the mentioned modern species and Mesozoic ones are mostly convergent and the Asian Mesozoic species of Allophalerus gen. nov. have not close relationship with the modern representatives of Tetraphalerus.

Comparison. This new genus is somewhat similar to other genera including slender ommatines with comparatively narrow prothorax, namely: Omma, Pareuryomma, Polyakius gen. nov. and Rhabdocupes; however the unique combination of the diagnostic characteristics can make easy recognition of the new genus which was frequently described as "Tetraphalerus". Besides, the elytra and general appearance of congeners of this genus are similar to those in Monticupes, but the elytral veins of species of Allophalerus gen. nov. are separately ended to Sc, while A1 and CuA of congeners of Monticupes are fused in distal part. In addition to this diagnostic feature, the head of both groups is different (longer and subparallelsided in Allophalerus gen. nov. and shorter and subtriangular in Monticupes).

Etymology. The name of this genus is formed from the Greek $\alpha \ddot{\lambda} \lambda \lambda_{\mathrm{o}} \varsigma$ (another) and stem of the generic name "Tetraphalerus". Gender masculine.

Genus Burmocoleus Kirejtshuk, gen. nov.

urn:lsid:zoobank.org:act:93949FD2-09B3-49B7-84D8-B486F79C56E6

Type species: Burmocoleus prisnyi Kirejtshuk, sp. nov. (Figures 5 and 6), fossil, Lower/Upper Cretaceous, Upper Albian/Lower Cenomanian; Myanmar: Kachin (Burmese amber).

Diagnosis. Body wide; head subquadrate and subparallelsided or subtriangular and moderately long, eyes located at base, temples very short; prothorax subspherical with incarinate sides; veins scarcely expressed, longitudinal rows of cells not quite regular and subparallelly terminated on Sc along lateral elytral edge; cells variable but more or less expressed; explanate elytral sides rather wide and with very large cells arranged in more or less expressed 2-3 longitudinal rows (two complete rows and one short row between them at elytral base), abdominal ventrites co-planar (abutting).

Notes. A certain similarity of the elytral structure of the first described species of this new genus and that of the elytron described by Hong [71] as "Brochocoleus punctatus" was a reason to join them in one genus but the elytra of these species have only a sketchy similarity, while the difference in other organs between two groups here considered as two genera, Brochocoleus and Burmocoleus gen. nov. is rather great (see the comparison below).

Comparison. This new genus has the elytra similar to those in Brochocoleus, Jarzembowskiops gen. nov. and Stegocoleus (with widely explanate elytral sides bearing very large cells); however Burmocoleus gen. nov. differs from them in the subglobular (subspherical) prothorax without lateral carinae (not explanate and incarinate at sides), and also from:

- Brochocoleus in the very large and almost irregular cells and lack of trace of veins on elytral disk, very narrow "neck" and very short temples and subquadrate scutellum;

- Jarzembowskiops gen. nov. in the irregular cells and lack of trace of veins on elytral disk, seriate large cells on explanate elytral sides;

- Stegocoleus in the irregular cells and lack of trace of veins on the elytral disc (not indistinctly striate and not with small cells between striae), seriate large cells on explanate elytral sides, and subquadrate scutellum. 
The prothorax of the new genus subglobular and uncarinate, reminiscent of that in species of Bukhkalius gen. nov., Cionocoleus, Cionocups gen. nov., Omma, Polyakius gen. nov. and Rhopalomma whose elytra, however, are completely different from that in Burmocoleus gen. nov. (see above notes to the mentioned genera and the diagnosis of Polyakius gen. nov.).

Composition. Type species and Burmocoleus zhiyuani (Liu, Tan, Ślipiński, Jarzembowski, Wang, Ren, et Pang, 2017) [117], comb. nov. [Brochocoleus].

Etymology. The name of this new genus is formed from the ancient name of the country (Burma) and

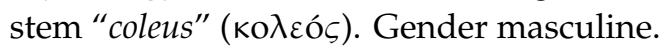

Burmocoleus prisnyi Kirejtshuk, sp. nov. (Figures 5 and 6)

urn: lsid:zoobank.org:act:164F4C0B-0F43-4DF3-90BA-89E17C7AD276

Holotype. ZIN Cuped 002. The specimen with removed posterior parts of elytra and abdomen, also with a missing part of the right mesotarsus, and part of the metatibiae and metatarsi is included in a flattened piece of amber (rectilinearly cut from one side $(26 \mathrm{~mm}$ ) and with suboval outline from another side with diameter $15 \mathrm{~mm}$ ). Also, the part of the underside of the prothoracic and head integument is also missing. The beetle is located along the oval edge of the amber piece with the broken posterior part near to the oval edge of the amber piece and beyond. Because of optical reason the sculpture of the integument is poorly visible, particularly from above. The piece of amber with the beetle also includes spores and pollen grains, many pieces of litter and organic matter different in shape and size, and also the chitinized fragments of insect bodies, including one separate mandible. The amber piece has also some cracks from the surface plane, from where the upper side of the beetle body accessible for observation.

Locality and age. Myanmar: Kachin (Hukawng Valley, Burmese amber), Lower/Upper Cretaceous, Upper Albian/Lower Cenomanian, -99.7-94.3 Ma.

Diagnosis. This new species is distinct from Burmocoleus zhiyuani comb. nov. in the clearly projecting part of the anterior edge of the elytra at the middle (but not the shoulder angle as in its congener), and also in the much narrower (subtriangular) frons, other proportions in the antennomeres, widely rounded anterior edge of the pronotum (like that in species of Omma) and only two long rows of large cells on the explanate elytral sides (without a short row of cells between them).

Notes. The name Burmocoleus zhiyuani comb. nov. was proposed for the holotype which can be compared with the holotype of the new species. Another specimen was used for the description of this species as a paratype. However this paratype is markedly slenderer than the holotype and has the structure of the head, antennae, pronotum, elytral outline and cells rather different from those in the holotype. The latter specimen certainly is a third congener of this new genus. Nevertheless, the head and pronotum of this paratype is somewhat similar to those in Burmocoleus prisnyi sp. nov., but not in B. zhiyuani comb. nov.

Description (holotype). Length without missing posterior part of body 14.8, width $6.2 \mathrm{~mm}$. Body slightly to moderately convex dorsally and subflattened ventrally, dark brownish; sclerites of dorsal surface and thoracic underside with very dense and uniform small microtubercles and with long and very fine hairs, forming ciliation along elytral sides (visible at high magnification).

Head subtriangular and rather narrowed apically, eyes located at base of head near distinctly isolated "neck", temples very short. Mandibles rather stout and rather developed and tridentate at apex. Antennae very thin, slightly shorter than head and prothorax together; their scape moderately long and thick (much thicker than tibial apex), antennomere 2 (pedicel) small (slightly longer than thick), antennomere 3 longest (about four time as long as antennomere 2 and twice as long as antennomere 4), antennomeres 4-10 subtriangularly widened apically and gradually becoming shorter, ultimate antennomere lanceolate and about as long as antennomere 7. Prothorax subglobular, wide basal orifice 
and narrow apical one from above, anterior and lateral outline forming contiguous contour with subuniform serration. Scutellum subquadrangular, slightly longer than wide and with slightly convex posterior edge. Elytra moderately convex along body and steeply sloping at widely explanate sides; lateral edge densely serrate, anterior edge with projection at middle; elytral disk apparently with almost irregular large cells (but markedly smaller than those on explanate sides) and without trace of veins, but explanate sides with two longitudinal rows of particularly large cells; anterior and lateral edges densely serrate.

Thoracic underside sclerites with somewhat obliterated microtubercles, and also with coarse and rather dense punctures having diameter about $3-5$ times as great as eye facets. Procoxae and metacoxae subcontiguous, mesocoxae very narrowly separated. Metaventrite slightly longer than mesoventrite, medially depressed, with discrimen and parametacoxal sutures. Metacoxae with mesal parts strongly projecting posteriorly. Abdomen with abutting junction of ventrites, ventrite 1 slightly extending behind apices of mesal part of metacoxae and about 1.5 times as long as each of ventrites 2-4 and ventrite 5 considerably longest (even its basal part without missing apical one).

Legs moderately long and with comparatively narrow tibiae and tarsi. Pro- and metafemora thickened at middle (nearly three times as thick as scape) and rather thin in distal third, mesofemur of usual shape, about twice as thick as scape. All tibiae very thin and gradually thickening apically, and well developed spur. Protibia with long and thin process at outer apical angle. Meso- and metatarsi with tarsomeres 1-4 slightly subconical and gradually shortening distally, tarsomere 5 longest. Protarsus about $3 / 4$ as long as protibia, protarsomere 1 slightly longer than each of protarsomeres 2-4, protarsomere 5 about as long as protarsomeres 1-4 together. Claws simple and thin, very long.

Etymology. The epithet of the new species is dedicated to entomologist Alexander Vladimirovich Prisny, who graduated from the Kharkov State University together with the author of this paper and who passed away in the summer of 2019.

Genus Cionocups Kirejtshuk, gen. nov.

urn:lsid:zoobank.org:act:23DCB581-2AD1-419C-9D2F-B71D9581461C

Type species Cionocups manukyani sp. nov. (Figures 7 and 8), fossil, Lower/Upper Cretaceous, Upper Albian/Lower Cenomanian; Myanmar: Kachin (Burmese amber).

Diagnosis. Body elongate oval; head about as wide as long, subtriangular and strongly narrowed at base (neck), eyes very large and located at base, temples very short; prothorax subspherical with incarinate sides; dorsal integument with diffuse, dense and comparatively coarse microtubercles; elytra with microtubercles intermixed by small oval cells comparable in size with microtubercles; explanate elytral sides moderately and with densely serrate along edges, abdominal ventrites apparently co-planar (abutting).

Comparison. This new genus is rather similar to Cionocoleus, but, in contrast to the latter, has the peculiar shape of the head with very large eyes and rather narrow neck, much longer antennae, dorsal integument with dense and high coarse microtubercles, on the elytra microtubercles are intermixed with small oval cells apparently, and elytral sides with distinctly serrate lateral edges

Composition. Type species (Cionocups manukyani sp. nov.) only.

Etymology. The name of this new genus is formed from the name of the closest taxon "Cionocoleus" and stem of the generic name "Cupes". Gender masculine.

Cionocups manukyani Kirejtshuk, sp. nov. (Figures 7 and 8)

urn:lsid:zoobank.org:act:014722E5-D1DE-4A55-95A2-D1D7FA8A90A7

Holotype. GPIH 4984, coll. C. Gröhn 11,186. The complete beetle is included in a flat amber piece of elliptic shape with the greater diameter $20.0 \mathrm{~mm}$ and smaller one $8.0 \mathrm{~mm}$ and height $3.3 \mathrm{~mm}$. The 
beetle is obliquely located on one side of this piece. Besides, this amber piece also has many transparent and mat gas bubbles (most of them below the beetle), some cracks in different directions and size (some of them passing through the beetle), and also some spores and pieces of organic matter of different size.

Notes. Some dorsoventral compression of the prothorax of this holotype examined could be at least partly lifetime, but mostly appeared as a sequence of postmortem deformation (it is clearly visible in on somewhat depressed pronotal base and irregularly subflattened elytra). The current careful observation showed that the prothoracic sides of this specimen are certainly incarinate, but the serration along the lateral edges of the pronotum looks like that along lateral the elytral sides rather than microtuberculation on the upper body sclerites.

Locality and age. Myanmar: Kachin (Hukawng Valley, Burmese amber), Lower/Upper Cretaceous, Upper Albian/Lower Cenomanian, -99.7-94.3 Ma.

Description (holotype). Length 7.3, width 2.7, height $0.8 \mathrm{~mm}$. Body subflattened dorsally (partly postmortem) and subflattened ventrally, dark chestnut brownish; sclerites of dorsal surface and thoracic underside with dense subuniform microtubercles and with dense rather conspicuous hairs, forming also short ciliation along elytral sides.

Head transversely subtriangular and rather narrowed apically, eyes strongly projecting and located at base of head near moderately expressed "neck", temples very short; transversely elevated at level of eyes and depressed before anterior edge, with slight covering over antennal insertion. Mandibles moderately long and gently curved to bidentate apices. Antennae very thin, somewhat longer than head and prothorax together; their scape moderately long and thick (much thicker than tibial apex), antennomere 2 (pedicel) moderately small (about twice longer than thick), antennomere 3 longest (about 2.5 times as long as each of antennomeres 2 and 4), antennomeres 4-10 subconical, ultimate antennomere lanceolate and about one and one quarter as long as each of antennomeres 4-10. Pronotum subflattened (partly as postmortem event) and with anterior edge forming line continuing arcuate lateral outlines, sides arcuately widening anteriorly, visible lateral contour with subuniform crenellation, base nearly straight. Scutellum apparently subquadrangular and with slightly convex posterior edge. Elytra moderately convex along body and apparently gently sloping to narrowly explanate sides; about 1.5 times as long as wide combined; lateral edge densely and sharply serrate, anterior edge almost straight; elytral disc apparently with diffuse microtubercles (without remnants of cells) and without veins, explanate sides with finer punctures; anterior and lateral edges densely serrate.

Genal processes of head rather wide, far projecting and exposed over level of mouthparts. Thoracic underside sclerites with somewhat obliterated microtubercles and also with coarse and moderately dense punctures having diameter somewhat greater than eye facets. Procoxae and metacoxae subcontiguous, mesocoxae very narrowly separated. Abdomen with abutting ventrites, ventrite 5 (hypopygidium) about 1.5 times as long as each of ventrites $2-4$ and apparently only slightly longer than ventrite 1.

All femora and tibiae of more or les usual shape, but very long and extremely narrow, every femur seemingly comparable in length with corresponding tibia. Tarsi very thin and very long, ultimate tarsomere longer than combined length of antennomeres 2-4; claws simple and thin, moderately long.

Etymology. The epithet of this new species is dedicated to Andranik Rafaelievich Manukyan for friendly professional communication and cooperation during many years, particularly for his help in preparation of many inclusions of fossil beetles.

Clessidromma zengi Kirejtshuk, sp. nov. (Figures 9 and 10)

urn:lsid:zoobank.org:act:2A59B74F-A5C4-415C-8C2D-40B169F2039D

Holotype. ZIN Cuped 003. The complete specimen is included in the amber piece with a shape of parallepiped (with facets about $10.0 \times 6.0 \times 2.1 \mathrm{~mm}$ ) having one facet (upper surface of the beetle) 
not completely flattened. This amber piece also includes some gas bubbles and some pieces of organic matter and litter with different size and shape.

Locality and age. Myanmar: Kachin (Hukawng Valley, Burmese amber), Lower/Upper Cretaceous, Upper Albian/Lower Cenomanian, -99.7-94.3 Ma.

Diagnosis. This new species in the general outlines of its body sclerites has a somehow intermediate position between two other congeners (Clessidromma palmeri and C. tianae comb. nov.) demonstrating also the mandibles being longer than those in both these species, peculiar shape of the pronotum, peculiar proportions of the antennomeres, smaller scales on the dorsal surface and along the pronotal and elytral sides. Clessidromma zengi sp. nov. differs from the slenderer member of the genus (Clessidromma palmeri) in the shorter head, "neck"-shaped pronotal base and elytra, and, on the other hand, differs from the more robust species (C. tianae comb. nov.) in the longer head, pronotum and elytra.

Description (holotype). Length 6.2, width 1.9 , height $0.9 \mathrm{~mm}$. Body slightly to moderately convex dorsally and subflattened ventrally, dark brownish; sclerites of dorsal surface and thoracic underside with very dense uniform and small microtubercles, and also with thick and very conspicuous hairs of different colouration (yellowish, brownish and blackish), intermixed by thinner hairs; dense and conspicuous pubescence masking integument and forming also ciliation along pronotal and elytral sides; dorsal vestiture on head, prothorax, mesoventrite and partly on base of elytra and profemora yellowish to reddish, while that on other parts markedly darker.

Head subtriangular and slightly narrowed apically, eyes strongly projecting and located at base of head near moderately expressed "neck", temples very short; upper surface rather transversely elevated at level of eyes and with elevated tubercle over place of each antennal insertion. Mandibles very long and sharply curved at blunt apices. Antennae very thin, somewhat longer than head and prothorax together; their scape moderately long and thick (much thicker than tibial apex), antennomere 2 (pedicel) moderately small (about twice longer than thick), antennomere 3 longest (nearly three times as long as each of antennomeres 2 and 4), antennomeres 4-10 gradually becoming thicker, ultimate antennomere lanceolate and almost twice as long as each of antennomeres 4-10. Pronotum subflattened and with short "neck"-shaped base, anterior edge rather convex and explanate at middle and with slight median emargination of explanate portion, sides widening anteriorly, rounded anterior angles and very stump posterior ones, contour with subuniform serration. Scutellum rather widened apically, slightly shorter than wide and with widely rounded posterior edge. Elytra moderately convex along body and gently sloping to moderately explanate sides; almost twice as long as wide combined and broadly arcuate at sides; anterior edge almost straight; elytral disk apparently with regular medium-sized cells and scarcely expressed veins, masked by dense vestiture, explanate sides with one longitudinal row of medium-sized cells; anterior and lateral edges densely and finely serrate.

Genal processes of head rather wide, far projecting and exposed over level of mouthparts. Labrum moderately exposed and with dense setae along transverse anterior edge. Mentum transverse, suboval to subpentagonal. Ultimate maxillary palpomere subconical and slightly narrowing apically, about 2.5 times as long as thick. Thoracic underside sclerites with somewhat smoothed microtubercles and also with coarse and rather dense punctures having diameter somewhat greater than eye facets. Procoxae and metacoxae subcontiguous, mesocoxae very narrowly separated. Metaventrite slightly longer than mesoventrite, medially depressed and apparently with parametacoxal sutures. Mesal processes of metacoxae very moderately extending posteriorly. Abdomen with abutting ventrites, ventrite 5 (hypopygidium) about 1.5 times as long as each of ventrites $2-4$ and slightly shorter than ventrite 1 .

Anterior legs very long and significantly longer than posterior ones, intermediate legs somewhat shorter than anterior ones and markedly longer than posterior ones. Pro- and mesofemora long and narrow, rather thicker in proximal half and very narrow at apex, profemur about 0.8 and mesofemur about 0.6 as long as antenna; metafemur moderately thickened in proximal half and about half as long as antenna. All tibiae narrow and comparable in length with corresponding femora, gradually 
thickening to apex, and with small spur. Protibia with moderately prominent and acute outer apical angle. Pro- and mesotarsi slightly longer and metatarsus markedly longer than corresponding tibiae; tarsomere 1 markedly longer than each of tarsomeres 2-4 and tarsomere 5 longer than tarsomeres 2-4 together; claws simple and thin, moderately long.

Etymology. The epithet of the new species is dedicated to Zeng Xiantai (Zhengzhou, Henan, China) for friendly relation in cooperation with the author, particularly for his help in receipt of inclusions of fossil beetles for the collection of ZIN.

Genus Jarzembowskiops Kirejtshuk, gen. nov.

\section{Zoobank}

Type species: Brochocoleus caseyi Jarzembowski, Wang et Zheng, 2016 [122], fossil; Lower/Upper Cretaceous, Albian/Cenomanian; Myanmar: Kachin (Burmese amber).

Composition. Only Jarzembowskiops caseyi comb. nov.

Diagnosis. Body wide oval; head long and subparallelsided, eyes located at base, temples very short; prothorax dorsoventrally compressed and widely subexplanate at carinate sides; elytra with shoulder angle slightly projecting anteriorly, veins very weakly expressed, longitudinal rows of rather small regular cells between veins and subparallelly terminated on Sc along lateral elytral edge; explanate elytral sides rather wide and with very large irregular cells, abdominal ventrites co-planar (abutting).

Comparison. This new genus has the charactertistic very widely explanate elytral sides with large cells, more or less similar to those in Brochocoleus, Burmocoleus gen. nov., Polyakius gen. nov. and Stegocoleus, however Jarzembowskiops gen. nov. differs from all mentioned genera in the very widely subexplanate pronotum and strongly projecting eyes, and also from:

- Brochocoleus in the finer cells and more expressed trace of veins on the elytral disc, diffuse very large cells on explanate elytral sides, very narrow "neck" and very short temples and subquadrate scutellum;

- Burmocoleus gen. nov. in the regular cells and exposed trace of veins on the elytral disc, diffuse large cells on explanate elytral sides;

- $\quad$ Polyakius gen. nov. in the more exposed trace of veins on the elytral disc, diffuse large cells on more widely explanate elytral sides, very narrow "neck", very short temples and subquadrate scutellum;

- $\quad$ Stegocoleus in the long head (not subtriangular) with very short temples, narrower explanate part of elytra, diffuse large cells on explanate elytral sides, and subquadrate scutellum.

Etymology. The name of this generic taxon is dedicated to Edmund Aleksander Jarzembowski, who made many discoveries of fossil archostematans and other fossil insects. Gender feminine.

Omma janetae Kirejtshuk, sp. nov. (Figures 13 and 14)

urn:1sid:zoobank.org:act:C60194E1-D91B-4764-856C-2A39CC1ACF34

Holotype. ZIN Cuped 004. The complete specimen is included into the amber piece with shape of parallepiped (with facets about $12.7 \times 7.3 \times 2.8 \mathrm{~mm}$ ) having one facet (at side of the underside of the beetle) not flattened and spherically curved. This amber piece also includes the remnants of leaves (one of them on the right part of the beetle body), many small gas bubbles and some small pieces of organic matter of different size and shape. This amber piece has some cracks of different size, obliquely oriented to the beetle body and one crack along the lower plane of the beetle.

Locality and age. Myanmar: Kachin (Hukawng Valley, Burmese amber), Early/Lower Cenomanian, -99.7-94.3 Ma.

Diagnosis. Omma janetae sp. nov. differs from: 
- O. aberratum in the somewhat smaller body, much larger eyes, shorter antennae but with comparatively longer antennomere 3 , comparatively shorter elytra, shorter ventrite 1 , narrower profemur;

- O. ancistrodontum comb. nov. in the transverse head with more prominent eyes, shape of pronotum, longer anterior and intermediate legs;

- $\quad$ O. avus in the shorter and transverse head with more prominent eyes, and shorter antennae;

- $\quad$ O. daxishanense in the shorter and triangular head with more prominent eyes and lack of both prominent temples and grooves, and less arcuate elytral sides;

- $\quad$ O. delicatum in the shorter head with more prominent eyes, and transverse pronotum;

- $\quad$ O. elongatum in the triangular transverse head with shorter antennae;

- $\quad$ O. jurassicum in the much shorter subtriangular head with very short temples and narrower elytra;

- O. liassicum in the markedly smaller body, somewhat smaller and shorter head, rounded anterior edge of pronotum;

- $\quad$ O. lii in the much slenderer body with more narrowly explanate elytral sides, shorter head more narrow anteriorly, rounded anterior edge of prothorax, longer antennomere 3

- O. pilosum in the shorter head with larger eyes, more rounded prothorax, narrower anterior femur;

- $\quad$ O. sibiricum in the much smaller body, somewhat arcuate elytral sides, narrow anterior femur.

The species regarded as questional members of Omma and marked in the above list with mark (?), including also $O$. brevipes are not mentioned in this comparison (see also the above Notes to the genus Omma).

Description (holotype). Length 8.6 , width 2.6 , height $1.1 \mathrm{~mm}$. Body moderately convex dorsally and ventrally, dark brownish; sclerites of dorsal surface and thoracic underside with very dense and subuniform microtubercles, and also with hairs of different thickness, colouration and conspicuousness, masking integument (particularly on elytra) and forming also ciliation along elytral sides; underside vestiture darker, with less raised and less conspicuous pubescence.

Head subtriangular and rather narrow apically, eyes strongly projecting and located near well expressed "neck", temples extremely short; upper surface rather transversely elevated at level of eyes and this elevation extending to level above place of antennal insertion, and slightly depressed frons. Labrum well exposed and far projecting anteriorly, its anterior edge transverse. Mandibles very long and arcuately curved at blunt apices. Antennae moderately thin, somewhat shorter than head and prothorax together; their scape moderately long and thick (somewhat thicker than tibial apex), antennomere 2 (pedicel) smallest and nearly globular, antennomere 3 longest (nearly three times as long as antennomere 2 and about 2.5 times as long as antennomere 4), antennomeres 4-10 subequal and subconical, ultimate antennomere lanceolate and almost twice as long as each of antennomeres 4-10. Pronotum nearly globular and incarinate, anterior outline rather convex and forming one continuous arc with lateral sides; posterior edge subrectilinear and posterior angles stumpy. Scutellum subtriangular, about as long as wide, with arcuate sides and rounded at apex. Elytra moderately convex along body and steeply sloping to narrowly explanate sides; somewhat more than 1.5 times as long as wide combined and very broadly arcuate at sides; anterior edge gently rounded; elytral disk apparently with almost regular sculpture (probably small suboval cells) and slightly expressed veins, masking by dense vestiture, narrow explanate sides with diffuse small microtubercles and small punctures; anterior and lateral edges finely and densely serrate.

Genal processes comparatively short and rather wide. Ultimate maxillary palpomere slightly thickening apically, about twice as long as thick. Thoracic underside sclerites with somewhat obliterated microtubercles and also with coarse and rather dense punctures having diameter markedly greater than eye facets. Procoxae and metacoxae subcontiguous, mesocoxae very narrowly separated. Metaventrite slightly longer than mesoventrite, medially depressed. Mesal processes of metacoxae very slightly extending posteriorly. Abdomen with abutting ventrites, ventrite 5 (hypopygidium) about 1.5 times as long as each of ventrites $2-4$ and only slightly longer than ventrite 1 . 
Anterior and intermediate legs rather long and significantly longer than posterior ones, intermediate legs somewhat shorter than anterior ones and markedly longer than posterior ones. Proand mesofemora long and narrow, profemur about 0.8 and mesofemur about 0.7 as long as antenna; moderately thick at base and moderately thin at apex. Metafemur rather thickened in proximal half and about half as long as antenna. All tibiae narrow and somewhat shorter than corresponding femora, with apical spur; protibia with rather prominent outer apical angle. Protarsus much shorter than protibia; protarsomeres 1-4 subcylindrical, moderately thick and with gradual shortening, protarsomere 5 about as long as protarsomeres 1 and 2 together. Meso- and metatarsi significantly longer than corresponding tibiae (metatarsus about 1.3 times as long as metatibia), meso- and metatarsomeres 1-4 rather narrow. Claws simple and thin, moderately long.

Notes. The sculpture and vestiture of this new species and the species of Omma, and also proportions of sclerites of different legs of Omma janetae sp. nov. are somewhat reminiscent of those in species of Clessidromma. These peculiarities could reflect some relationship of these ommatines.

Etymology. The epithet of this new species is dedicated to the wife (Janet) of Albert Allen who donated the holotypes of two new ommatine species described in this paper.

Genus Polyakius Kirejtshuk, gen. nov. (Figures 16 and 17)

1sid:zoobank.org:act:C60194E1-D91B-4764-856C-2A39CC1ACF34

Type species Polyakius alberti sp. nov. (Figure 16), fossil; Lower/Upper Cretaceous, Albian/Cenomanian; Myanmar: Kachin (Burmese amber).

Composition. Type species and Polyakius pubescens sp. nov.

Diagnosis. Body comparatively wide; head moderately long and subtriangular, eyes located at base, temples extremely short; prothorax slightly dorsoventrally compressed but incarinate at sides; elytra with shoulder angle slightly projecting anteriorly, veins apparently very weakly expressed, longitudinal rows of moderately large cells regular between veins and subparallelly terminated on Sc along lateral elytral edge; explanate elytral sides moderately wide and with large regular cells arranged in one row, abdominal ventrites co-planar (abutting).

Comparison. This new genus is similar and closely related to the genus Omma, differing from it mostly in some level of dorsoventral compression of the body, and also the presence of a regular row of large cells along the lateral elytral edge and very dense and comparatively long dorsal vestiture consisting of very thin hairs. Polyakius gen. nov. differs from Burmocoleus gen. nov., Cionocoleus, Cionocups gen. nov. and Bukhkalius gen. nov. in the regular cells on the elytral disc and only with one row of large cells along the lateral edge of the elytron; differs also from Rhopalomma in the short head with distinct neck and very short temples, independent ending of $\mathrm{A} 1$ and $\mathrm{Cu}$ (without fusion of $\mathrm{A} 1$ and $\mathrm{Cu}$ at elytral apex) and with one row of large cells along lateral edge of elytron (but not with diffuse microtubercles).

Etymology. The name of this new genus is devoted to my class mate, Vladimir Aronovich Polyak, with whom the author was in close and friendly relationship for more than than 50 years.

Polyakius alberti Kirejtshuk, sp. nov. (Figure 16)

urn:lsid:zoobank.org:act:0481DB85-ABBF-4B12-90EF-42F9561F343A

Holotype. ZIN-Cuped-01. The elliptic flat amber piece $(25.0 \times 16.0 \mathrm{~mm})$ with height of $3.6 \mathrm{~mm}$ includes the beetle with more or less good preservation of the upper surface and rather bad one of its underside. The beetle specimen is almost complete but with missing left antenna, preapical right antennomeres, distal parts of profemora, protibiae and protarsi. It looks somewhat dorsally compressed because some deformation is observable on the pronotum and probably of the elytral base, a part of the upper surface and most of the beetle underside has a "milky" cover and it is difficult to observe structural details. This amber piece has some cracks in different directions, including the 
largest one in the plane of the elytral lateral edges of the beetle, and contains many small pieces of organic matter different in colour, size and shape, and also many small gas bubbles.

Locality and age. Myanmar: Kachin (Hukawng Valley, Burmese amber), Early/Lower Cenomanian, -99.7-94.3 Ma.

Diagnosis. This new species differs from another congener (P. pubescens sp. nov.) in the smaller and slenderer body, shape of the pronotum and steeply sloping elytral sides, comparatively longer head, proportions of the basal antennomeres, shorter pubescence on the elytra, somewhat larger cells on disk and explanate sides of elytra.

Description (holotype). Length 14.6, width 4.9, height $1.1 \mathrm{~mm}$. Body slightly convex to subflattened dorsally and subflattened ventrally, dark brownish; sclerites of head and pronotum densely microtuberculate, prosternum distinctly and densely punctured; body integument with dense hairs masking sculpture and colouration, upper surface with much longer and more conspicuous hairs and with many small gas bubbles between them forming along elytral lateral edges distinct ciliation, underside with shorter hairs.

Head subtriangular, about 0.7 times as long as pronotum, slightly longer than wide and rather narrowed apically, eyes rather prominent and located at base of head, "neck" well expressed and moderately narrow, temples very short; upper surface rather transversely elevated at level of eye base and with tubercle above each antennal insertion. Mandibles moderately raised and sharply curved at apparently sharp apices. Antennae moderately long and moderately thin, somewhat shorter than head and prothorax together, their scape of usual proportion and thickness (poorly visible but probably thicker than tibial apex), antennomere 2 (pedicel) very small (about twice longer than thick), antennomere 3 longest (nearly five times as long as antennomere 2 and about 2.5 times as long as antennomere 4), antennomeres 4-7 (antennomeres 8-11 missing) subequal and slightly thickened apically. Prothorax apparently initially subglobular; pronotum about as wide as long, subflattened (in life more or less convex but postmortem deformed) and with uniformly arcuate anterior edge, subflattened at posterior angles. Scutellum subquadrate to subpentagonal, widest at apex, apparently somewhat longer than wide. Elytra subflattened above body and rather steeply sloping to widely explanate sides; slightly more than twice as long as wide combined and broadly arcuate at sides; anterior edge gently arcuate; elytral disc apparently with regular medium-sized cells and probably veins (not visible because of dense vestiture and extremely small gas bubbles between hairs), explanate sides with one longitudinal rows of large cells; anterior and lateral edges densely serrate.

Metaventrite significantly shorter than mesoventrite, medially subflattened and apparently with parametacoxal sutures. Abdomen with abutting ventrites, ventrite 5 (hypopygidium) about as long as ventrite 1 , ventrites $2-4$ subequal in length and each of them apparently almost twice as short as ventrite 1 or hypopygidium.

Procoxae and metacoxae subcontiguous, mesocoxae extremely narrowly separated. Intermediate legs markedly longer than posterior ones. Mesofemur thickened in proximal half, about 1.3 times as long as metafemur and about 1.3 times as long as head. Meso- and metatibiae comparable in length with corresponding femora. Mesotarsus slightly longer than mesotibia, mesotarsomere 1 about as long as mesotarsomere 5 and about as long as mesotarsomeres 2-4 together. Metatarsus about 1.5 times as long as metatibia, metatarsomere 5 about as long as metatarsomeres 3 and 4 . Claws simple and thin, moderately long.

Etymology. The epithet of this new species is dedicated to Albert Allen who donated the holotypes of two new ommatine species described in this paper.

Polyakius pubescens Kirejtshuk, sp. nov. (Figure 17)

urn:lsid:zoobank.org:act:4CFAA645-24DA-4C05-929C-FBC9D93FC000 
Holotype. ALDC0450/ALD.Bu.195 for deposition in ZMUC. Suboval to subtriangular flat unclear amber piece with one rectiliner facet $(24.0 \times 17.0 \mathrm{~mm})$ with height of $3.6 \mathrm{~mm}$ includes the beetle with more or less good preservation of upper surface and rather bad preservation of its underside, which is covered with mat and not transparent amber layer. The beetle specimen seems to be almost complete but only the upper integument can be observable, although many small gas bubbles over the abdomen and a considerable part of the right elytron make observation of these structures very complicated. The specimen could be somewhat postmortem compressed.

Locality and age. Myanmar: Kachin (Hukawng Valley, Burmese amber), Early/Lower Cenomanian, -99.7-94.3 Ma.

Diagnosis. See the above Diagnosis of another congener (Polyakius alberti sp. nov.).

Description (holotype). Length 21.0 , width $7.7 \mathrm{~mm}$. Body slightly convex dorsally and apparently subflattened ventrally, dark brownish; sclerites of head and pronotum densely microtuberculate, upper integument with dense straw reddish hairs masking sculpture and colouration, upper surface with much longer and more conspicuous hairs and with many small gass bubbles between them forming along elytral lateral edges distinct ciliation, underside with shorter hairs.

Head subtriangular, about 0.6 times as long as pronotum, slightly shorter than long and rather narrowed apically, eyes rather prominent and located at base of head near moderately narrow and well expressed "neck", temples almost absent; upper surface rather transversely elevated at level of eyes base. Antennae apparently moderately long and moderately thin, apparently much shorter than head and prothorax together, antennomere 3 longest (could be 1.5 times as long as antennomere 4), antennomeres 4-7 (antennomeres 8-11 missing) subequal and scarcely thickened apically. Prothorax apparently initially subglobular; pronotum transverse (more than 1.5 times as wide as long), somewhat subflattened (intravitally more or less convex but postmortally deformed) and with uniformly arcuate anterior edge, not subflattened at posterior angles. Scutellum, widest at rounded apex, apparently somewhat wider than long. Elytra subflattened above body and rather steeply sloping to widely explanate sides; slightly more than 1.5 times as long as wide combined and very broadly arcuate at sides; anterior edge gently arcuate; elytral disc apparently with regular medium-sized cells and veins and other interspaces between longitudinal rows of cells comparably raised), explanate sides with one longitudinal row of large cells; anterior and lateral edges densely serrate.

Etymology. The epithet of this new species means "haired", "hirsute".

\section{Notes on the Subfamily Ommatinae}

The genus Fuscicupes Hong and Wang 1990 [145] (type species: Fuscicupes parvus Hong et Wang, 1990 [145]; China: Shandong Province (Tuanwang Village, Laiyang City); Lower Cretaceous, Aptian/Albian, -125.5-112.6 Ma) was proposed after the description of one specimen with very poor preservation and lack of characteristics for supposition on a connecting it with any suborder or family, although a general body outline of the print is partly reminiscent of elateroids.

The holotype of "Tetraphalerus" brevicapitis Ponomarenko et Martinez-Delclòs, 2000 [163] (Spain, Sierra del Montsec (La Cabrua outcrop), Lower Cretaceous, Early/Lower Barremian, -130.0-125.5 Ma) has no character to identify the genus but the outlines of its underside sclerites are reminiscent of some ommatines (perhaps particularly species of Diluticupes).

\section{Subfamily Triadocupedinae Ponomarenko, 1966}

Type species: Triadocupes Ponomarenko, 1966 [109]; fossil; Middle/Upper Triassic; Kyrgyzstan. (five genera, 17 species)

Comments. Composition and position of this subfamily are discussed in Kirejtshuk et al. (2016). It differs from other subfamilies mostly in more or less widely separated procoxae (like those in cupedine genera Cretomerga A. Kirejtshuk, Nel et P. Kirejtshuk, 2016 [33] and Taxopsis A. Kirejtshuk, Nel et P. Kirejtshuk, 2016 [33]), also longitudinal rows of very large cells between weakly expressed 
interspaces (remains of veins) and widely explanate elytral sides. All these characteristics do not form a distinct hiatus of this group from Cupedinae and probably can be considered as a tribe of the subfamily Cupedinae.

Genus Cupesia Ponomarenko, 1966 [102]. Type species: Cupesia monilicornia Ponomarenko, 1966 [102], by monotypy. Three species.

Other congeners: Cupesia sepulta Ponomarenko, 1969 [26], Cupesia serricornia Ponomarenko, 1969 [26].

Kyrgyzstan: Osh Region (Madygen, Dzhailoucho area); Middle/Upper Triassic, Ladinian/Carnian, -235.0-221.5 Ma.

Genus Moltenocupes Zeuner, 1961 [123]. Type species: Moltenocupes townrowi Zeuner, 1961 [123], by monotypy. One species.

South Africa: Kwazulu-Natal (Umkomaas Valley (Umk 111), Middle/Upper Triassic, Ladinian/Carnian, -235.0-221.5 Ma; Eastern Cape (Konings Kroon (Rooipoort)), Middle/Upper Triassic, Ladinian/Carnian, -235.0-221.5 Ma; Burnera Water Fall (Upper Umkomaas), Middle/Upper Triassic, Ladinian/Carnian, -235.0-221.5 Ma.

Notes. This genus was preliminarily put into Triadocupedinae by Ponomarenko [26] and characterized by the free veins ending at the elytral apex, comparatively small ultimate abdominal segment and rather large mandibles.

Genus Platycupes Ponomarenko, 1966 [102]. Type species: Platycupes dolichocerus Ponomarenko, 1966 [102], by original designation. Four species.

Other congeners: Platycupes major Ponomarenko, 1966 [102], Platycupes pusillus Ponomarenko, 1966 [102], Platycupes reticulatus Ponomarenko, 1966 [102].

Kyrgyzstan: Osh Region (Madygen, Northern area and Dzhailoucho area); Middle/Upper Triassic, Ladinian/Carnian, -235.0-221.5 Ma.

Genus Procupes Ponomarenko, 1966 [102]. Type species: Procupes mandibularis Ponomarenko, 1966 [102], by monotypy. One species.

Kyrgyzstan: Osh Region (Madygen, Northern area); Middle/Upper Triassic, Ladinian/Carnian, $-235.0-221.5 \mathrm{Ma}$.

Genus Triadocupes Ponomarenko, 1966 [102]. Type species: Triadocupes ferghanensis Ponomarenko, 1966 [102], by original designation. Three species.

Other congeners: Triadocupes ellipticus Ponomarenko, 1966, Triadocupes latus Ponomarenko, 1966.

Kyrgyzstan: Osh Region (Madygen, Dzhailoucho area); Middle/Upper Triassic, Ladinian/Carnian, -235.0-221.5 Ma.

\section{Subfamily Cupedinae Laporte, 1836}

Type genus: Cupes Fabricius, 1801 [99] (= Priacmini Crowson, 1962; type genus: Priacma LeConte, 1861 [76]; Mesocupedini Ponomarenko, 1969; type genus: Mesocupes Martynov, 1926 [119])

(19 genera, 67 species)

Comments. The preliminary revision of this subfamily was recently published by Kirejtshuk et al. [33]. Some new discoveries brought very important additions to the systematics of this group (for examples, $[164,165]$; etc.). In this publication only results of the mentioned revision and papers are reviewed without partition into tribes because of absence of reliable diagnostic characteristics for their discrimination.

Genus Anaglyphites Ponomarenko, 1964 [103]. Type species: Anaglyphites clavatus Ponomarenko, 1964 [103], by original designation. Seven species. 
Other congeners: Anaglyphites admotus Ponomarenko, 1964 [103], Anaglyphites capitatus Ponomarenko, 1966 [109], (?) Anaglyphites crassipygus Ponomarenko, 2014 [151], Anaglyphites minimus (Ponomarenko, 1997) [105] [Priacmopsis], (?) Anaglyphites minutissimus Ponomarenko, 2014 [151], Anaglyphites mongolicus Ponomarenko, 1997 [105].

Russia: Buryatia (Transbaikalia, Baissa), Lower Cretaceous, Aptian, -125.5-112.6 Ma.

Kazakhstan: Chimkent Region (Mikhailovka), Middle/Upper Jurassic, Callovian Oxfordian, $-164.7-155.7$ Ma.

Mongolia: Gobi-Altay Aimag (Shar-Teg); Upper Jurassic, Tithonian, -150.8-145.5 Ma;

Bayan-Khongor Aimag (Bon Tsagaan), Lower Cretaceous, Barremian, -130.0-125.5 Ma; Bayan-Khongor Aimag (Khurilt and Bon Tsagaan), LowerCretaceous, Aptian, -125.45-112.6 Ma.

Notes. This taxon was joined with Mesocupes and Cainomerga by Kirejtshuk et al. [33] as one of the subgenera of Mesocupes. A closer relation of most members of Mesozoic Anaglyphites and Mesocupes to regard them as subgenera of one genus could be really reasonable, but the Cenozoic Cainomerga would be better considered as a separate genus. The hiati of the above-mentioned taxa look like quite comparable, although the Cenozoic group seems to have more ground to be considered separately from the two Mesozoic ones [33]. At the moment it is difficult to find a balanced decision for their placement and these related taxa are temporally treated as separate genera. The first of all it is necessary to re-examine again the holotype of the type species of Anaglyphites (A. clavatus) and to clarify its subfamily attribution. Also it would be advisable to check type materials of other members of both Anaglyphites and Mesocupes. Some of them do not demonstrate reliable characteristics for linking them with neither most members of Anaglyphites nor with the type species of this genus and, therefore, they are marked in the above list by "?".

Genus Apriacma A. Kirejtshuk, Nel et P. Kirejtshuk, 2016 [33]. Type species Priacma tuberculosa Tan, Ren et Shih, 2006, by original designation. Four species.

Congeners: Apriacma clavata (Tan, Ren et Shih, 2006) [166] [Priacma], (?) Apriacma latidentata (Tan, Ren et Shih, 2006) [166] [Priacma], Apriacma renaria (Tan, Ren et Shih, 2006) [166] [Priacma], Apriacma tuberculosa (Tan, Ren et Shih, 2006) [166] [Priacma].

China: Liaoning Province (Huangbanjigou, Chaomidian Village), Lower Cretaceous, Lower Aptian, -125.5-122.5 Ma.

Genus Barbaticupes Jarzembowski, Wang et Zheng, 2017 [165]. Type species: Barbaticupes cobertae Jarzembowski, Wang et Zheng, 2017 [165], by monotypy. One species.

Myanmar: Kachin (Hukawng Valley, Burmese amber), Early/Lower Cenomanian, -99.7-94.3 Ma.

Notes. This genus is distinguished by its very prominent tubercles on the upper surface of the head and pronotum. It is also characterized by the fused of $\mathrm{A} 1$ and $\mathrm{Cu}$ before the elytral apex, rather short metacoxae and lobed tarsomere 4. Meanwhile, the holotype and paratype of Barbaticupes cobertae seem to be different species and, therefore, a more detailed characteristics of this genus needs a revision of both.

Genus Cainomerga A. Kirejtshuk, Nel et P. Kirejtshuk, 2016 [33], stat. nov. Type species: Mesocupes (Cainomerga) brevicornis A. Kirejtshuk, Nel et P. Kirejtshuk, 2016 [33], by original designation. Five species.

Congeners: Cainomerga brevicornis (A. Kirejtshuk, Nel et P. Kirejtshuk, 2016) [33], comb. nov. [Mesocupes], Cainomerga fraterna (A. Kirejtshuk, Nel et P. Kirejtshuk, 2016) [33], comb. nov. [Mesocupes], Cainomerga immaculata (Piton, 1940: 194) [33], comb. nov. [Zonabris, Mesocupes], Cainomerga palaeocenica (A. Kirejtshuk, Nel et P. Kirejtshuk, 2016) [33], comb. nov. [Mesocupes], Cainomerga ponti (A. Kirejtshuk, Nel et P. Kirejtshuk, 2016) [33], comb. nov. [Mesocupes].

France: Auvergne (Menat), Palaeogene, Palaeocene, Thanetian, -58.7-55.8 Ma.

Note. See the above Notes to the genus Anaglyphites. 
Genus Cretomerga A. Kirejtshuk, Nel et P. Kirejtshuk, 2016 [33]. Type species: Priacmopsis subtilis Tan et Ren, 2006 [167], by monotypy. One species.

China: Liaoning Province (Huangbanjigou, Chaomidian Village), Lower Cretaceous, Lower Aptian, -125.5-122.5 Ma.

Genus Cupes Fabricius, 1801 [99] (Figures 20-22). Type species: Cupes capitatus Fabricius, 1801 [99], by monotypy, recent (=Cupoides Motschulsky, 1856 [168], type species: Cupoides tesselatus Motschulsky, 1856 [168], by monotypy, fossil; Tenomerga Neboiss, 1984 [169], type species: Cupes mucidus Chevrolat, 1829 [170], by original designation, recent; Distocupes Neboiss, 1984 [169], type species: Cupes varians Lea, 1902 [171], by original designation, recent). 20 species.

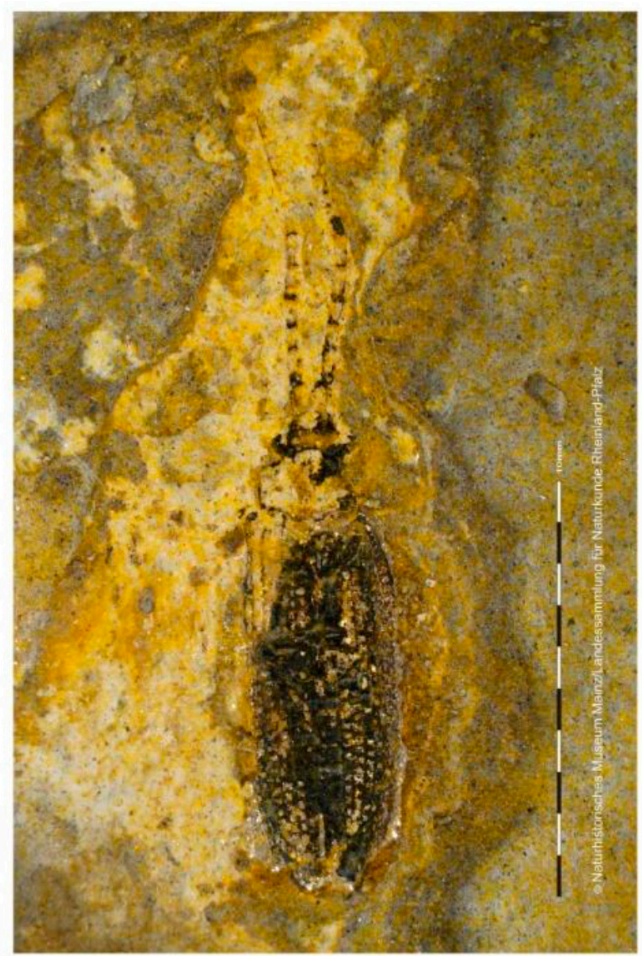

ma

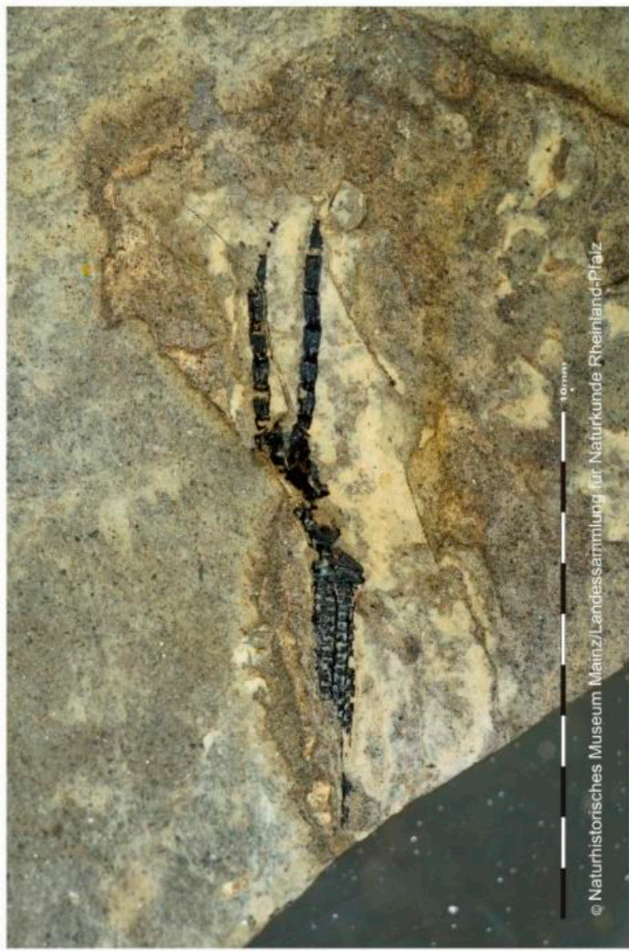

A

B

Figure 21. Cupedinae (Cupedidae). Cupes lutzi sp. nov. from Eckfeld (Palaeogene, Eocene, Lutetian; Eifel, Eckfeld Maar): A-B-holotype, PE 200001141-a (LNNR), part (A) and PE 200001141-b (LNNR), counterpart. Scale for each picture provided. Original.

Fossil congeners: Cupes distinctissimus A. Kirejtshuk, Nel et P. Kirejtshuk, 2016 [33], Cupes eckfeldensis (Tröster, 1993) [172] [Tenomerga], Cupes golovatchi sp. nov. (Figure 20A,B), Cupes groehni Kirejtshuk, 2005 [173], Cupes hoffeinsorum Kirejtshuk, 2005 [173], Cupes kerneggeri Kirejtshuk, 2005 [173], Cupes komissari Kirejtshuk, 2005 [173], Cupes legalovi sp. nov. (Figure 20C,D), Cupes longus Hong et Wang, 1987 [174], Cupes lutzi sp. nov. (Figure 21), Cupes manifestus Kirejtshuk, Nel et Collomb, 2010 [57], Cupes messelensis (Tröster, 1993) [172] [Tenomerga], Cupes ponomarenkoi Kirejtshuk, Nel et Collomb, 2010 [57], Cupes praeglacialis Gersdorf, 1976 [175], Cupes rohdendorfi Iablokoff-Khnzorian, 1960 [176], Cupes nabozhenkoi sp. nov. (Figure 22A,B), Cupes simillimus A. Kirejtshuk, Nel et P. Kirejtshuk, 2016 [33], Cupes tesselatus (Motschoulsky, 1856) [168] [Cupoides] (= tesselata Peierimhoff, 1909 [177] [Priacma]), Cupes wedmannae sp. nov. (Figure 22C,D), Cupes weitschati Kirejtshuk, 2005 [173]. 

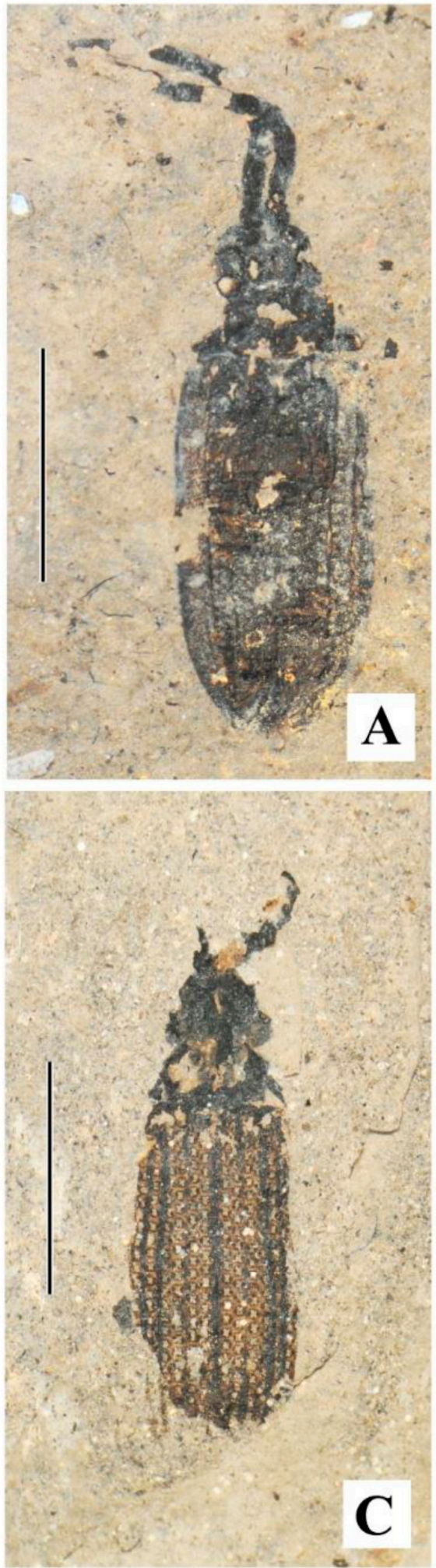
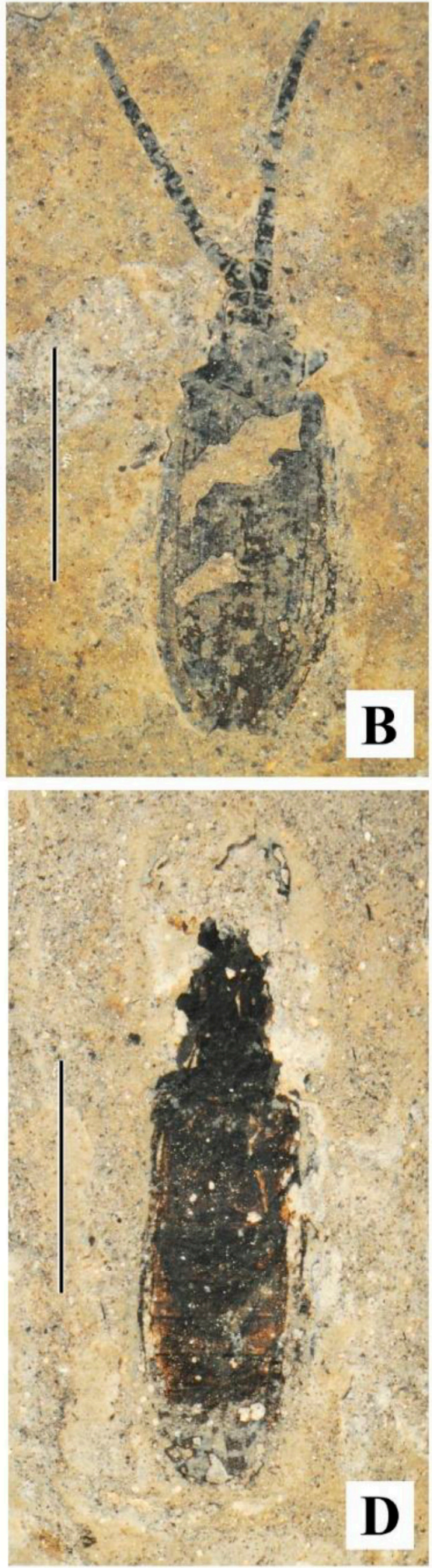

Figure 22. Cupedinae (Cupedidae). species of Cupes from Messel (Palaeogene, Eocene, Lutetian Hessen (Grube Messel Pit)): A-B-Cupes nabozhenkoi sp. nov.: A-holotype, MeI4010-01 (SFNFM), scale bar $=2.6 \mathrm{~mm}$; original. B-paratype, MeI11220-01 (SFNFM), scale bar $=6.2 \mathrm{~mm}$; original. C-D—Cupes wedmannae sp. nov., holotype, MeI4386A, part and MeI4386B, counterpart (SFNFM), scale bar for $\mathrm{C}=4.1 \mathrm{~mm}$, scale bar for $\mathrm{D}=2.6 \mathrm{~mm}$; original. 

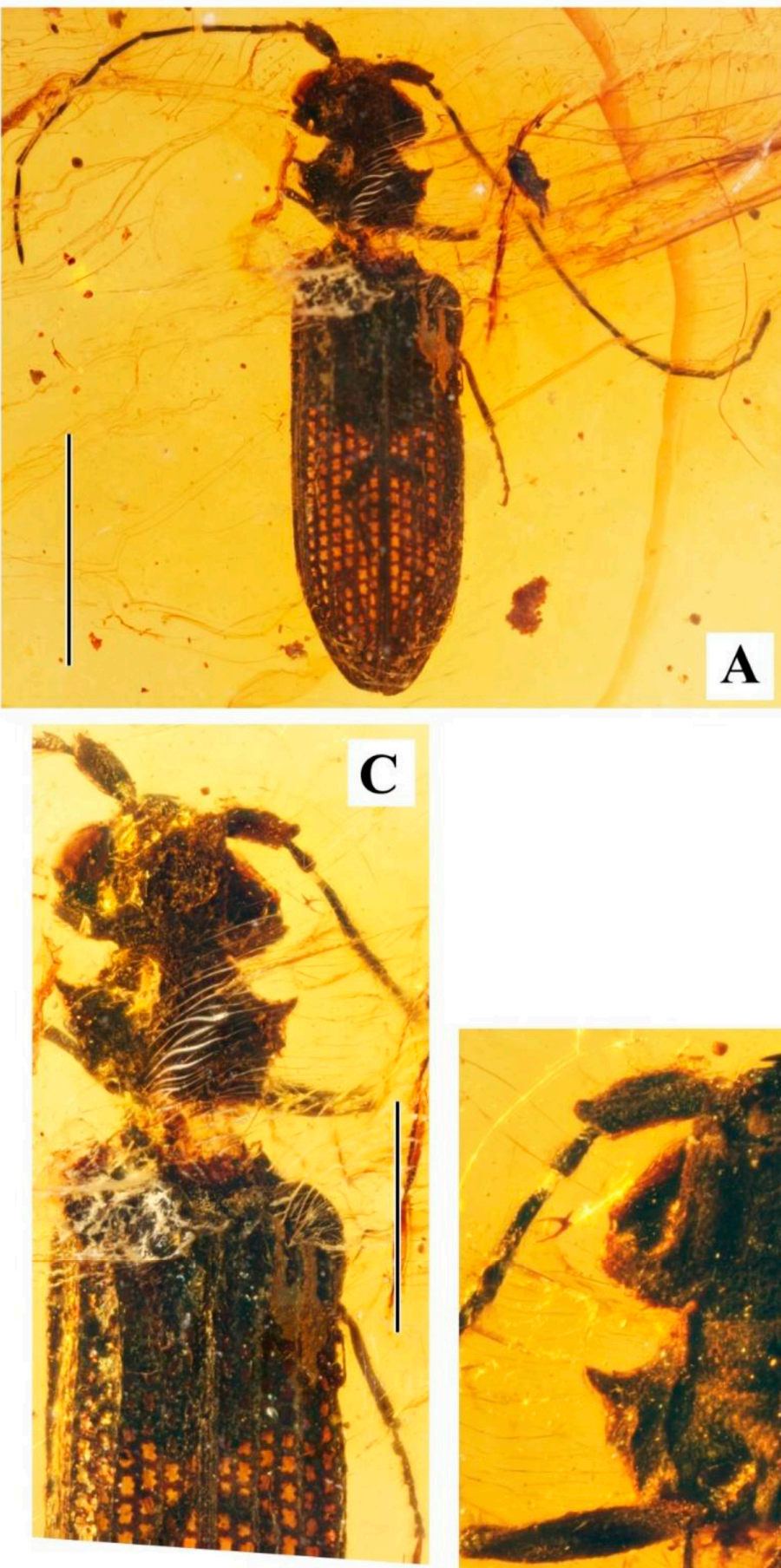
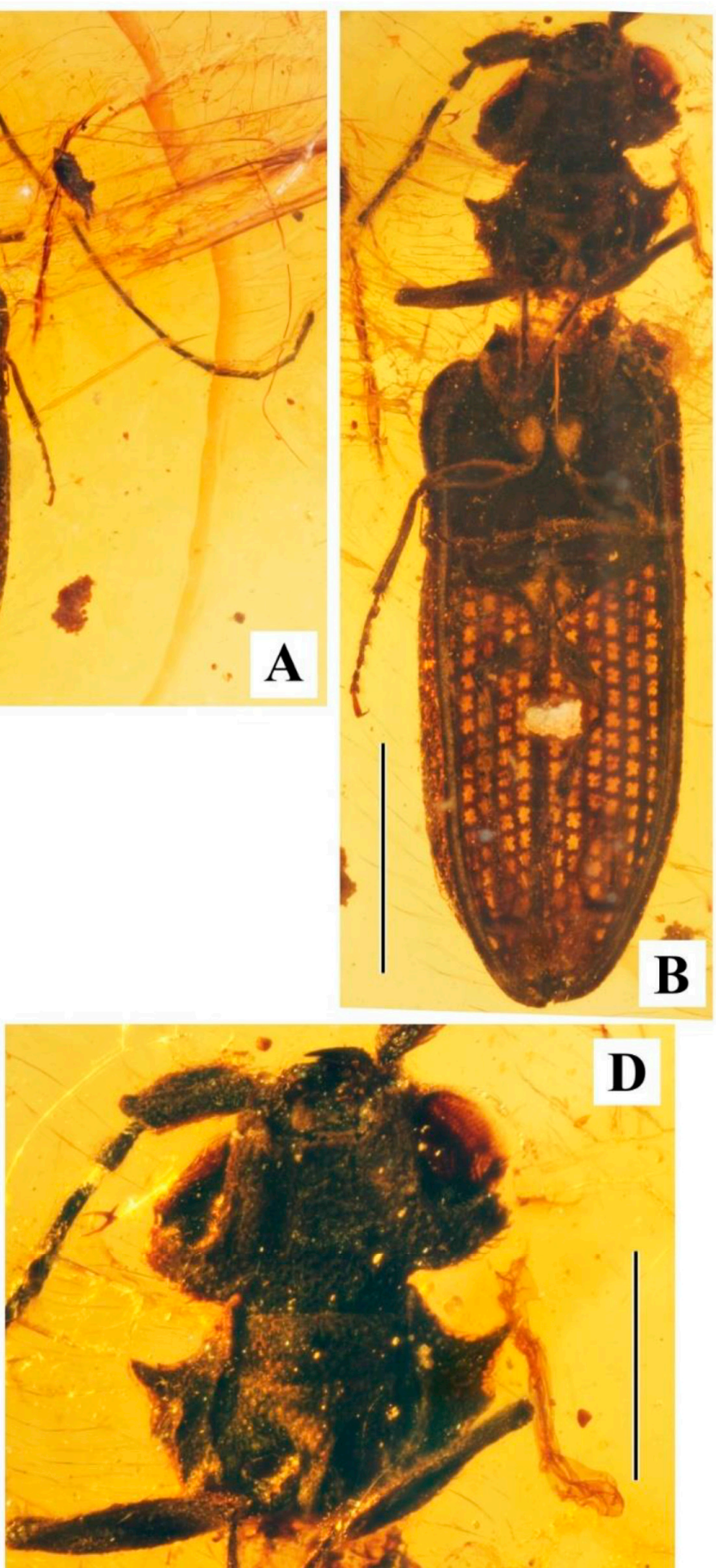

Figure 23. Cupedinae (Cupedidae). Mallecupes prokini sp. nov., holotype, GPIH 4985, coll. Gröhn 11192 (Lower/Upper Cretaceous: Upper Albian/Lower Cenomanian; Myanmar, Kachin, Burmese amber): A — body with antennae, dorsal; B — same without antennae, ventral, C — anterior part of body, dorsal; D-head and prothorax, ventral; length of inclusion $6.3 \mathrm{~mm}$, scale bar for $\mathbf{A}=1.9 \mathrm{~mm}$. scale bar for $\mathbf{B}=1.3 \mathrm{~mm}$, scale bar for $\mathbf{C}=1.1 \mathrm{~mm}$, scale bar for $\mathbf{D}=0.8 \mathrm{~mm}$; original. 

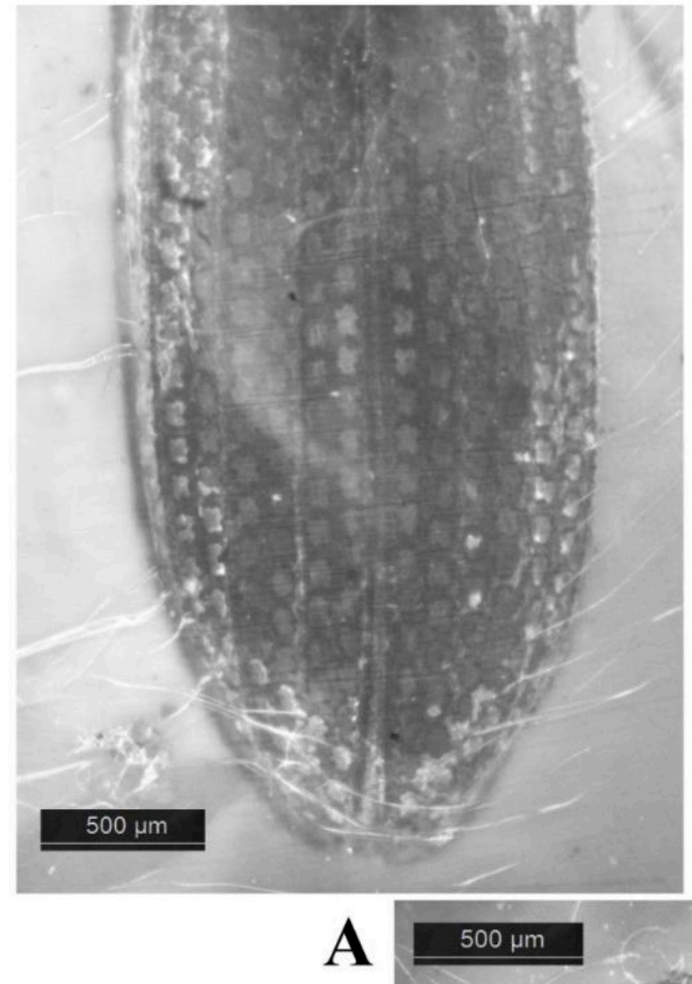

A

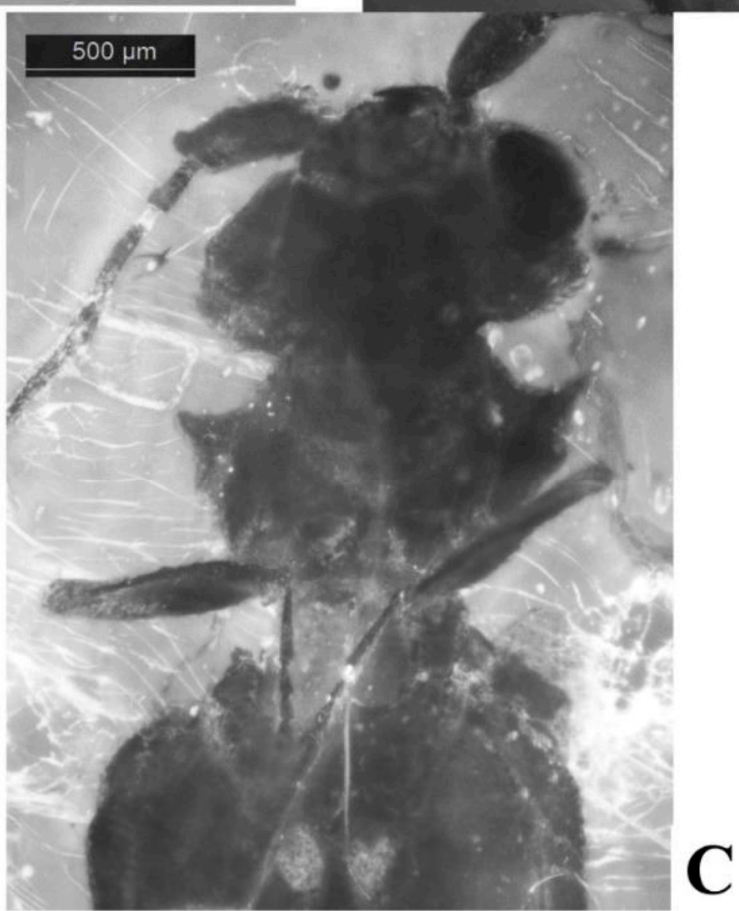

Figure 24. Cupedinae (Cupedidae). Mallecupes prokini sp. nov., holotype, GPIH 4985, coll. Gröhn 11192 (Lower/Upper Cretaceous: Upper Albian/Lower Cenomanian; Myanmar, Kachin, Burmese amber); fluorescent microscopy with filter set N21: A-elytra, dorsal; B-distal part of metaventrite, elytra, right mesotibia and mesotarsus, posterior legs, ventral; C-head, prothora and mesothorax with appendages, ventral; length of inclusion $6.3 \mathrm{~mm}$; scale for each picture provided; original.

France: Oise (Le Quesnoy, Oise amber), Palaeogene, Lowermost Eocene, Ypresian, -55.8-48.6 Ma; Auvergne (Menat), Palaeogene, Palaeocene, Thanetian, -58.7-55.8 Ma. Germany: Eifel (Eckfeld Maar), Palaeogene, Eocene, Lutetian -48.6-40.4 (44.3 +/- 0.4) Ma; Hessen (Grube Messel Pit, grid square E9), Palaeogene, Eocene, Lutetian, -48.6-40.4 Ma; Niedersachsen (Willershausen clay pit), Neogene, Pliocene, Piacenzian, -3.6-2.6 Ma.

Russia, Kaliningrad region (Baltic Amber), Palaeogene, Eocene, Priabonian, -37.2-33.9 Ma. 
China: Shandong Province (Shanwang, Linqu County), Neogene, Miocene, Burdigalian, -20.4-16.0 Ma.

Notes. The cupedines are absent in the Recent European fauna, however, there are some species of cupedines described from different Cenozoic palaeofaunas [33,57,172,173,175,178] till the Pliocene [175], and, therefore, the disappearance of cupedines in Europe was associated with last climatic and biotic changes in Europe. Most diversity of Cenozoic cupedines has been recorded in Eocene Baltic amber [174], and also in the outcrops of Messel and Eckefeld with the Lutetian age.

Unfortunately, many specimens from both last localities have bad preservation and cannot be described with characteristics acceptable for diagnostics and only few species are here described in addition to the species described by Tröster [173].

This genus in the here recognized interpretation could be a more or less heterogenous group including some monophyletic groups which would be better to consider as separate genera. The most Cupes species from Baltic amber [174] are more or less similar to those from the modern fauna and can be considered as genuine congeners, although one generic taxon was erected from the Baltic cupedines [57]. The some species from Eckfeld and Messel, including species here described as members of the genus Cupes, have, in contrast to most other "congeners", the comparatively wide elytral (sub) explanate sides and correspondingly epipleura and it is possible to expect some level of isolation making possible to propose for them a separate genus. The elytral sides of Cupes eckfeldensis and C. lutzi sp. nov. are somewhat explanate and with a row of large cells along the lateral edge. Besides, the elytral cells of the mentioned species are somewhat transverse and reminiscent of those in Taxopsis motschulskyi [33], but the prosternal process at least of C. eckfeldensis is narrow like that in other members of Cupes. Finally, Cupes nabozhenkoi sp. nov. have the somewhat (sub) explanate lateral sides of elytra with dense and diffuse microtubercles. Nevertheless, all species here joined in the genus Cupes share a very similar elytral venation and seem to be rather close relatives.

Cupes messelensis is included in the above list as a name for a separate species, however for now no character was found in the holotype which can be used as diagnostic one. See also below the Descriptions of new taxa of the subfamily Cupedinae.

Genus Cupidium Ponomarenko, 1968 [107]. Type species: Cupidium abavum Ponomarenko, 1968 [107], by monotypy. One species.

Kazakhstan: Chimkent Region (Mikhailovka); Upper Jurassic, Callovian/Oxfordian, -164.7-155.7 Ma.

Genus Cupopsis A. Kirejtshuk, Nel et P. Kirejtshuk, 2016 [33]. Type species: Paracupes svetkoi Lubkin, 2003 [179]. One species.

USA: New Jersey, Middlesex County (Old Crossman's Clay Pits), Upper Cretaceous, Cenomanian/Turonian, -94.3-89.3 Ma.

Genus Furcicupes Tan et Ren, 2006 [167]. Type species: Furcicupes raucus Tan et Ren, 2006 [167], by monotypy. One species.

China: Liaoning Province (Huangbanjigou, Chaomidian Village), Lower Cretaceous, Lower Aptian, -125.5-122.5 Ma.

Genus Gracilicupes Tan, Ren et Shin, 2006 [180]. Type species: Gracilicupes crassicruralis Tan, Ren et Shin, 2006 [180], by original designation. Three species.

Other congeners: (?) Gracilicupes minimus Strelnikova, 2019 [153], Gracilicupes tenuicruralis Tan, Ren et Shin, 2006.

Russia: Buryatia (Khasurty), Lower Cretaceous, Aptian, -125.5-112.6 Ma.

China: Nei Mongol (Daohugou), Middle/Upper Jurassic, Callovian/Oxfordian, -164.7-155.7 Ma.

Notes. Strelnikova described the new species as a third member of this genus ("Gracilicupes" minimus) considering that this species in the composition of the genus Gracilicupes can be diagnosed as a member of the tribe Mesocupedini. This attribution would be desirable to re-estimate in accordance with the 
characteristics of two other members of Gracilicupes and the characteristics proposed as diagnostic for Notocupedini. According to the authorial pictures (not text description and drawings) this species can be scarcely put in this genus because of its shape of pronotum, type of junction of abdominal ventrites, elytral structure and apparently venation.

Genus Kirghizocupes Ponomarenko, 1966 [102]. Type species: Kirghizocupes cellulosus Ponomarenko, 1966 [102] (=Mesocupoides Ponomarenko, 1969 [26], types species: Mesocupoides proporeus Ponomarenko, 1969 [26], by original designation). Three species.

Congeners: Kirghizocupes cellulosus [102], Kirghizocupes indistinctus Ponomarenko, 1969 [26] [Mesocupoides], Kirghizocupes proporeus [102] [Mesocupoides].

Kyrgyzstan: Osh Region (Madygen, Dzhailoucho area); Middle/Upper Triassic, Ladinian/Carnian, $-235.0-221.5 \mathrm{Ma}$.

Genus Latocupes Ren et Tan, 2006 [147]. Type species: Latocupes fortis Ren et Tan, 2006 [147], by original designation (?=Pulchicupes Ren, 1995 [98], type species: Pulchicupes jiensis Ren, 1995 [98], by monotypy). Six species.

Congeners: Latocupes angustilabialis (Tan, Huang et Ren, 2007) [181] [Mesocupes], Latocupes bella Ren et Tan, 2006 [147], Latocupes collaris (Tan, Huang et Ren, 2007) [181] [Mesocupes], Latocupes fortis, (?) Latocupes jiensis [Pulchicupes], Latocupes latilabialis (Tan, Huang et Ren, 2007) [181] [Mesocupes].

China: Beijing Shi (Chongqing Reservoir), Lower Cretaceous, Late/Upper Aptian, -122.5-112.6 Ma; Liaoning Province (Huangbanjigou, Chaomidian Village), Lower Cretaceous, Lower Aptian, -125.5-122.5 Ma; Nei Mongol (Daohugou), Middle/Upper Jurassic, Callovian/Oxfordian, $-164.7-155.7 \mathrm{Ma}$.

Genus Mallecupes Jarzembowski, Wang et Zheng, 2017 [164] (Figures 23 and 24). Type species: Mallecupes qingqingae Jarzembowski, Wang et Zheng, 2017 [164]. Two species.

Another congener: Mallecupes prokini sp. nov.

Myanmar: Kachin (Hukawng Valley, Burmese amber): Early/Lower Cenomanian, -99.7-94.3 Ma.

Note. This genus is characterized by the elongate and subflattened body; transverse head with more or less large eyes, rather expressed neck and very long antennae; medium-sized subflattened pronotum with explanate and carinate sides; elytra steeply sloping to narrowly subexplanate sides, with distinct veins and, CuA ending on A1, large cells arranged in double longitudinal rows; and abdominal ventrites abutting and markedly depressed anteriorly. This genus is most similar and closely related to Gracilicupes, but, in contrast to the latter, has transverse head with medially concave frons. Mallecupes seems to be closely related also to the Meso-Cenozoic Priacma, Mesozoic Apriacma, Barbaticupes, Furcicupes and Kirghizocupes, and also to Cenozoic Cupes, but differs from them at least in the very long antennae, transverse head and rather large eyes. See below the Descriptions of new taxa of the subfamily Cupedinae.

Genus Menatops A. Kirejtshuk, Nel et P. Kirejtshuk, 2016 [33]. Type species: Cupes orbiculatus Kirejtshuk, Nel et Collomb, 2010 [57], by original designation. Two species.

Congeners: Menatops bartenevi A. Kirejtshuk, Nel et P. Kirejtshuk, 2016 [33], Menatops orbiculatus [Cupes].

France: Auvergne (Menat), Palaeogene, Palaeocene, Thanetian, -58.7-55.8 Ma.

Genus Mesocupes Martynov, 1926 [119]. Type species: Mesocupes primitivus Martynov, 1926 [119], by monotypy. Six species.

Other congeners: Mesocupes bidens Ponomarenko, 1964 [103], Mesocupes minor Ponomarenko, 1968 [107], Mesocupes paulus (Ponomarenko, 1964) [103] [Anaglyphites], Mesocupes spinosus Ponomarenko, 1964, Mesocupes zherichini (Soriano et Delclos 2006: 194) [Anaglyphites].

Spain: Cuenca Province, (Las Hoyas), Lower Cretaceous, Upper Barremian, -130.0-125.5 Ma.

Kazakhstan: Chimkent Region (Karatau-Karabastau, Karatau-Galkino, Mikhailovka), Middle/Upper Jurassic, Callovian Oxfordian, -164.7-155.7 Ma. 
Note. See the above Notes to the genus Anaglyphites.

Genus Miocupes Ponomarenko, 1973 [178]. Type species: Miocupes rihai Ponomarenko, 1973 [178], by monotypy. One species.

Czech Republic: Pochlovice, Neogene, Miocene, Burgidalian, -16.9-16.0 Ma.

Genus Priacma LeConte, 1861. Type species: Priacma serrata LeConte, 1861, by monotypy. One species. Fossil congener: Priacma megapuncta Li et Cai, 2019 [182].

Myanmar: Kachin (Hukawng Valley, Burmese amber): Early/Lower Cenomanian, -99.7-94.3 Ma.

Genus Priacmopsis Ponomarenko, 1966 [109]. Type species: Priacmopsis adumbrata Ponomarenko, 1966 [109], by monotypy. One species.

Russia: Buryatia (Transbaikalia, Baissa), Lower Cretaceous, Aptian, -125.5-112.6 Ma.

Genus Taxopsis A. Kirejtshuk, Nel et P. Kirejtshuk, 2016 [33]. Type species: Cupes motschulskyi Kirejtshuk, 2005 [174], by monotypy. One species.

Russia: Kaliningrad region (Baltic Amber), Palaeogene, Eocene, Priabonian, -37.2-33.9 Ma.

\section{New Taxa of the Subfamily Cupedinae}

Cupes golovatchi Kirejtshuk, sp. nov. (Figure 20A,B)

urn:lsid:zoobank.org:act:329119A4-D097-4674-B902-26F43D2FEA79

Holotype. Represented by the part PE 200001146-a (LNNR) and counterpart 200001146-b (LNNR). The part demonstrates the dorsal integument of the body with elytra, distal parts of profemora, left antenna with eight antennomeres and right antenna with three antennomeres. The counterpart has only some remains of the structures observable in the part. Some sclerites of both part and counterpart are not clearly outlined in the holotype (particularly head with appendages and cells of the elytra). The tuberculation on head and pronotum is not traceable (except of the tubercle over antennal insertion), sculpture of integument of head, pronotum and elytra are very obscure because of postmortal transformation of the matrix entombed of the holotype.

Locality and age. Germany: Eifel (Eckfeld Maar), Palaeogene, Eocene, Lutetian, -48.6-40.4 (44.3 +/0.4) Ma.

Diagnosis. This new species is characterized by the comparatively wide transverse head rather narrowed anteriorly and with rather projecting temples, comparatively thick antennae, subpentangular pronotum subequal in width with head and rather arcute elytral sides. Except for the peculiar shape of pronotum, Cupes golovatchi sp. nov. differs from other species from comparatively contemporary European outcrops in Eckfeld and Messel in the following characteristics:

C. eckfeldensis in the smaller body, apparently shorter antennae, smaller and not transverse cells and narrow elytral sides and epipleura (lack of row of large cells on explanate elytal side along lateral edge);

Cupes legalovi sp. nov. in the markedly smaller and slenderer body, comparable width of prothorax and head;

Cupes lutzi sp. nov. in the smaller body, narrow elytral edge and narrow elytral sides and epipleura (lack of row of large cells on explanate elytral side along lateral edge);

Cupes nabozhenkoi sp. nov. in the much slenderer body, small difference in width of the pronotun abd elytra and narrow elytral sides (not (sub) explanate);

Cupes wedmannae sp. nov. in the smaller body, more arcuate lateral edges of comparatively shorter elytra.

Description (holotype) (Figure 20A,B). Length of part till traced abdominal apex $7.6 \mathrm{~mm}$. Elongate and apparently moderately convex dorsally. Head transverse, about 1.5 times as wide as long, subtriangular and rather narrowed anteriorly, with comparatively large eyes, rather large longitudinal tubercle 
over antennal insertion, and with large and rather projecting temples. Antennae apparently slightly extending behind middle of elytra, rather thick (scape and flagellomeres with comparatively small difference in thickness); scape longest and thickest, apparently at least three times as long as pedicel (antennomere 2) and more or less longer (apparently 1.5 to 2.0 times) than each of flagellomeres gradually becoming shorter apically. Pronotum slightly less than twice as wide as long, subpentangular and with gently and weakly convex posterior edge, moderately to rather arcuately convex anterior edge; subrectilinearly widened lateral edges between distinct stump posterior angles and also distinct, slightly acute and slightly projecting anterior angles. Elytra one and three-fourths as long as combined width, slightly to moderately arcuately curved along lateral edge, moderately and conjointly acuminate at apices, with well expressed primary veins, large and apparently subquadrate cells; epipleura comparatively narrow (comparable with those in modern species). Pygidium very widely rounded to transverse at apex. Profemora comparatively short and apparently rather thick, slightly longer than pronotum and with apices moderately extended beyond lateral edges of pronotum.

Etymology.The epithet of this new species is dedicated to Sergey Il'ich Golovatch, outstanding expert in myriapods and friend of the author during many years.

Cupes legalovi Kirejtshuk, sp. nov. (Figure 20C-D)

urn:lsid:zoobank.org:act:5A16CAFB-8F46-4F95-B64E-24457352FEF8

Holotype. Represented by the part PE 1992000522-a (LNNR) and counterpart PE 1992000522-b (LNNR). The part demonstrates the ventral integument of the head base, thorax with elytra without clear remains of cells, abdomen, profemora and protibiae, mesofemora and some places with clear remains of sculpture. The counterpart shows the head with antennal bases, some part of prothoracic underside sclerites, metaventrite, right part of other thoracic sclerites with the right elytron having the remains of cells, abdominal sclerites, profemora and protibiae. The sculpture of elytra can be studied due to the comparatively good preservation of the integument of the left elytron partly put away from the abdomen.

Locality and age. Germany: Eifel (Eckfeld Maar), Palaeogene, Eocene, Lutetian, -48.6-40.4 (44.3 +/0.4) Ma.

Diagnosis. This new species is characterized by the comparatively wide body, very wide and comparatively short prothorax with arcuate lateral edges. These features distinguish Cupes legalovi sp. nov. from other species known from all comparatively contemporary European outcrops in Eckfeld and Messel, and also from other congeners.

Description (holotype) (Figure 20C,D). Length $11.7 \mathrm{~mm}$ (better measureable in counterpart). Elongate and apparently rather convex dorsally. Head transverse, about twice as wide as long, subtriangular and rather narrowed anteriorly, with moderately large eyes, and with large and rather projecting temples somewhat extending posteriorly. Antennae with visible two first antennomeres, scape twice longer than thick; also twice as long as and about 1.5 times as thick as pedicel (antennomere 2). Prothorax about 2.5 times as wide as long; prosternum with shallowly bi-emarginate anterior edge and with moderately narrow prosternal process; pronotum with regularly and weakly convex posterior edge, arcuately widened lateral edges between distinct stump posterior angles and also distinct, slightly acute and slightly projecting anterior angles. Meso- and metathoracic sclerites, including metacoxae, very similar to those in modern species, although metaventrite markedly shorter. Elytra with very narrow epipleura and cells rather large and somewhat transverse. Abdomen with the overlapping junctions of ventrites and clear transverse roller at base of ventrites 2-5, hypopygidium longer than each of other ventrites and widely rounded at apex. Legs moderately long and rather thick, profemur much longer than prothorax, protibiae widened apically.

Etymology. The epithet of this new species is dedicated to Andrey Alexandrovich Legalov, close colleague of the author, with whom he published many papers on fossil beetles. 
Cupes lutzi Kirejtshuk, sp. nov. (Figure 21)

urn:lsid:zoobank.org:act:DF6C8D6F-D91B-4BD6-99A3-B39C92FFEEE5

Holotype Represented by the part PE 200001141-a (LNNR) and counterpart PE 200001141-b (LNNR). The part demonstrates the dorsal integument of the head with complete antennae, most part of pronotum, scutellum, most part of elytra and left intermediate leg; some outlines of underside sclerites are traceable (at least metaventrite with metacoxae). The counterpart shows the part of the head with the antennomeres $1-7$, right side of the pronotum, apex of mesofemur and mesotibia, and also lateral side of the right elytron. The sculpture of elytra is observable in some places of both part and counterpart.

Locality and age. Germany: Eifel (Eckfeld Maar), Palaeogene, Eocene, Lutetian -48.6-40.4 (44.3 +/ 0.4) Ma.

Diagnosis.This new species is characterized by the comparatively wide body, comparatively short prothorax and one longitudinal row of large cells along lateral edge of elytra. Cupes lutzi sp. nov. is very similar to C. eckfeldensis, but distinct from it in the outlines of the prothoracic sides.

Description (holotype) (Figure 21). Length $10.6 \mathrm{~mm}$. Elongate and apparently moderately convex dorsally. Head transverse, about twice as wide as long, subtriangular and rather narrowed anteriorly, apparently with comparatively large eyes, large tubercle over antennal insertion, and with large and rather projecting temples. Antennae apparently slightly extending behind distal third of elytra, moderately thick to thin (scape and flagellomeres with rather great difference in thickness); scape longest and thickest, more than three times as long as pedicel (antennomere 2) and more or less longer (about 1.5 times) than each of flagellomeres subequal in length. Pronotum about twice as wide as long, subpentangular to subhexangular, rather convex at posterior edge with more prominent its median part (forming tri-sinuate outline: median emargination and and two paramedian sinuations), rather arcuately convex anterior edge (also forming somewhat bi-sinuate outline); very slightly subrectilinearly widened lateral edges between distinct stump posterior angles and also distinct, nearly right and not projecting anterior angles. Scutellum somewhat transverse, subpentagonal with rounded apex. Elytra about 2.4 times as long as combined width, slightly arcuately curved along lateral edge, broken apices, with weakly expressed primary veins, large and apparently subquadrate to somewhat transversely quadrangular cells; somewhat (sub) explanate lateral sides with one row of large cells, epipleura comparatively narrow (comparable with those in modern species). Pro- and mesofemora moderately long and apparently rather thick, slightly longer than pronotum and with apices moderately extended beyond lateral edges of pronotum; protibia somewhat widened to apex.

Etymology. The epithet of this new species is dedicated to Herbert Lutz, curator of fossil beetles in LNNR.

Cupes nabozhenkoi Kirejtshuk, sp. nov. (Figure 22A,B)

urn:lsid:zoobank.org:act:329119A4-D097-4674-B902-26F43D2FEA79

Holotype. Represented by one print MeI4010-01 (SFNFM). The specimen remains in the print the dorsal integument of the head with partly destroyed antennae, pronotum, scutellum, most part of elytra, anterior legs exposed beyond pronotum and median part of pygidium; some outlines of underside sclerites are traceable (at least the intermediate legs, metaventrite with metacoxae).

Paratype. Represented by one print MeI11220-01 (SFNFM). The remains of the specimen show the almost complete outline dorsal integument with destroyed some places of the elytra in the middle and along their lateral edges; besides, the apices of the profemora and bases of protibiae are partly exposed beyond the pronotal sides, and also a fragment of the left intermediate leg is visible. 
Locality and age. Germany: Hessen (Grube Messel Pit, grid square E9), Palaeogene, Eocene, Lutetian, -48.6-40.4 Ma.

Diagnosis. This new species is characterized by the comparatively large eyes, subparallelsided pronotum with regularly rounded anterior and posterior edges, and also elytra much wider than pronotum. The mentioned characterictics makes it possible to recognize this new species among the species known from comparatively contemporary European outcrops in Eckfeld and Messel.

Description (holotype) (Figure 22A,B). Length $5.3 \mathrm{~mm}$. Elongate oval and apparently moderately convex dorsally. Head transverse, about 1.5 times as wide as long, subtriangular and moderately narrowed anteriorly, apparently with rather large eyes, and with moderately raised temples. Antennae apparently slightly extending behind middle of elytra, moderately thick (scape and flagellomeres with small difference in thickness); scape longest and thickest, about 2.5 times as long as pedicel (antennomere 2) and more or less longer (about 1.5 times) than each of flagellomeres subequal in length. Pronotum about twice as wide as long, subquadrangular, slightly and regularly convex at posterior edge and rather arcuately convex anterior edge; subrectilinearly parallelsided atsides, with distinct stump anterior and posterior angles. Scutellum very large and transverse, subtriangular with widely rounded apex. Elytra about twice as long as combined width, slightly arcuately curved along lateral edge, apices subangular separated, with well expressed primary veins, large and apparently subquadrangular to subpolygonal cells; somewhat (sub) explanate lateral sides with dense and diffuse microtubercles, epipleura apparently rather wide. Exposed part of pygidium showing widely rounded apex. Profemora moderately long and apparently rather thick, markedly longer than pronotum and with apices moderately extended beyond lateral edges of pronotum; protibia somewhat widened to apex.

Paratype. Length $8.5 \mathrm{~mm}$. Visible outlines of dorsal surface similar to those in holotype, but head about twice as wide as long and with traceable paired tubercles: one pair over antennal insertions and one pair behind them; pronotum with median carina; sculpture of elytra less clear than in holotype.

Etymology. The epithet of this new species is dedicated to maxim Vital'evich Nabozhenko, close colleague of the author, with whom he published many papers on fossil beetles.

Cupes wedmannae Kirejtshuk, sp. nov. (Figure 22C,D)

urn:lsid:zoobank.org:act:B1716D2E-86E1-43A0-9D12-6566DF045F99

Holotype. Represented by the part MeI4386A (SFNFM) and counterpart MeI4386B (SFNFM). The part shows the dorsal integument of the head with the left scape and right antennomeres 1-4, pronotum, most part of elytral discs and exposed apex of left profemur and base of left protibia; sculpture of elytral integument is more or less observable. The counterpart has the observable the same organs, but with rather obscure outlines more destructed antennae, and, alternatively, with some traces of the elytral parts (including the outlines of elytral apices) absent in the holotype part and very weak and obscure traces of some thoracic sclerites and legs.

Notes. This new species is assigned to the genus Cupes despite the missing characterictics of the sculpture of the elytral apices because the good clarity of the primary veins and the presence of the large and regularly seriate cells in elytra (not diffuse and small cells or punctures). All other important characterictics of both Cupes and Miocupes are rather similar.

Locality and age. Germany: Hessen (Grube Messel Pit, grid square E9), Palaeogene, Eocene, Lutetian, -48.6-40.4 Ma.

Diagnosis. This new species is characterized by the very peculiar shape of comparatively long pronotum with the almost straight posterior edge of pronotum and also the anterior edge rather far projecting anteriorly. This feature very distinguishes this species among all the congeners. Besides, it 
distinct among the contemporary European congeners from Eckfeld and Messel in the comparatively long head with small eyes and strongly projecting temples.

Description (holotype) (Figure 22C-D). Length of part 9.8, length of counterpart $5.1 \mathrm{~mm}$. Elongate and apparently moderately convex dorsally. Head transverse, about one and one-seventh as wide as long, subtriangular and very narrowed anteriorly, with comparatively small eyes, two pair of tubercles (over antennal insertions and along eyes) and with strongly raised temples, represented by only four right antennomeres, with moderately thick (scape and flagellomeres with small difference in thickness); scape longest and thickest, about 2.5 times as long as pedicel (antennomere 2) and more or less longer (about1.5 times) than each of flagellomeres 3 and 4 subequal in length. Pronotum about 1.5 times as wide as long, subpentangular; subrectilinear to shallowly subemarginate at posterior edge and strongly arcuately convex anterior edge (strongly projecting anteriorly); subrectilinearly widened from distinct posterior angles to distinct anterior angles. Scutellum not visible. Elytra about 2.5 times as long as combined width, very slightly arcuately curved to rectilinear along lateral edge, apices subangular separated, with well expressed veins, large and apparently subquadrangular to subpolygonal cells; apparently somewhat (sub) explanate lateral sides with one row of large cells

Etymology. The epithet of this new species is dedicated to Sonja Wedmann, curator of fossil beetles in SFNFM.

Mallecupes prokini Kirejtshuk, sp. nov. (Figures 23 and 24)

urn:lsid:zoobank.org:act:3DB00189-6979-4433-998D-DD73E9435AB6

Holotype. GPIH 4985, coll. Gröhn 11192. The beetle specimen with missing right eye and abdomen and desegmented in the pro-mesothoracic junction is included into the flat amber piece with an suboval shape which is rectilinearly cut at one longer diameter $(16.0 \times 13.0 \mathrm{~mm})$ and with height $1.3 \mathrm{~mm}$. This amber piece some different amber layers, and it is also included some small pieces of organic matter and litter with different size and shape, and apparently some fungal hyphae.

Locality and age. Myanmar: Kachin (Hukawng Valley, Burmese amber), Lower/Upper Cretaceous, Upper Albian/Lower Cenomanian, -99.7-94.3 Ma.

Diagnosis. This new species is similar to another congener (Mallecupes qingqingae) and differs from the latter at least in the large and rather prominent temples, and shape of pronotum with the sharp and comparatively long lateral processes. Besides, Mallecupes prokini sp. nov. has the extremely steeply sloping elytral sides forming angle between flat plane of the disc of the elytron and sloping plane almost or even less than 90\%, apparently markedly lesser than that in Mallecupes qingqingae.

Notes. The type series of Mallecupes qingqingae consists of some specimens which seem to belong to at least two species. The pictured holotype NIGP 157008 and drawn paratype NIGP 164791 have the same characteristics different from those in Mallecupes prokini sp. nov. (see above), however each of these specimens looks enough different to regard them as separate species.

Description (holotype) (Figures 23 and 24). Length 6.3, width 1.3, height $0.7 \mathrm{~mm}$. Body rather convex dorsally and subflattened ventrally, very dark brown; sclerites of dorsal surface and thoracic underside with very dense uniform and extremely small microtubercles, and also with thin and slightly conspicuous hairs, on dorsal integument apparently intermixed by narrow scales.

Head subtriangular, strongly transverse and rather narrowed apically, eyes rather large and located between rather prominent temples and very short frons; "neck" distint and short, nearly one third as thick as head wide; temples very short; upper surface apparently rather smoothed. Mandibles comparatively short and sharply curved at acuminate apices. Antennae very thin, somewhat shorter than body length; its scape moderately long and comparatively thin (almost as thin as femora); antennomere 2 (pedicel) rather small (about three times as thick as long and one third as long as each of antennomeres 1 and 2); other antennomeres subcylindrical, very long and very thin; antennomere 3 
apparently longest and next antennomeres gradually becoming shorter, ultimate antennomere gently narrowing at acute apex. Pronotum subflattened, anterior part from very sharp processes (anterior angles) gently narrowing to transverse anterior edge, sides widening anteriorly from subrectilinear posterior edge, posterior angles stump, contour not even but not serrate. Scutellum somewhat widened apically, slightly shorter than wide and with widely rounded posterior edge. Elytra very flat at discs and very steeply (subvertically) sloping to sides (very narrow epipleura), about 2.5 times as long as wide combined and subparallelsided in three-fourths of length; elytral disk and sloping sides with regular comparatively large cells and well subparallel and expressed veins ending on Sc; anterior and lateral edges smooth (not serrate).

Genal processes of head very short and wide. Thoracic underside sclerites of usual shape and proportions. Procoxae distinctly separated by narrow process somewhat widened at transverse apex. Mesocoxae about as narrowly separated as procoxae. Metacoxae subcontiguous. Metaventrite about as long as mesoventrite, medially depressed and apparently with parametacoxal sutures. Mesal processes of metacoxae very far extending posteriorly, rather wide at base and sharply narrowing posteriorly, forming deep and comparatively widely triangular interspace between them.

Anterior legs very long and markedly longer than intermediate and posterior ones. All femora long and narrow, of usual subelliptic shape, thickest along midlength. All tibiae extremely narrow and comparable in length with corresponding femora, subparallelsided, and with small spur. Pro- and mesotarsi slightly longer and metatarsus nearly 1.5 times as long as corresponding tibiae; protarsomere 1 markedly longer (almost twice) than each of tarsomere 2-4 and tarsomere 5 longer than tarsomeres 2-4 together. Meso- and metatarsomeres 1 slightly longer than each of corresponding meso- and metatarsomeres 2-4. Claws simple and thin, moderately long.

Etymology. The epithet of this new species is dedicated to Alexander Alexandrovich Prokin, colleague of the author, with whom he published many papers on fossil beetles.

Funding: The author studies were partly carried out under the framework of the Russian state research project no. AAAA-A19-119020690101-6, programme of the Presidium of the Russian Academy of Sciences "Evolution of the organic world. Significance and influence of planetary processes", Russian Foundation of Basic Research (grant N_ 18-04-00243-a, and 19-04-00465-a). Besides, during some years the author studies were supported by different grants of MNHN when he was there as the visiting professor, including the programme 'Research in Paris' of the City of Paris (Mairie de Paris) and Sorbonne Universités (Programme d'Accueil de Chercheurs de Haut niveau).

Acknowledgments: The author had a pleasure to receive various and generous assistance from many colleagues in studies of fossils during many years that made possible the preparation of this paper. The rather important influence on the author studies of fossils during many years was from Alexander G. Ponomarenko (PIN). The author had many possibilities to study the collections of different museum and institutions, in first turn collection of PIN and MNHN and during his visits he had friendly contacts with many colleagues of these organizations, particularly with Thierry Deuve (MNHN), Antoine Mantilleri (MNHN), Olivier Montreuil (MNHN), Andrè Nel (MNHN), Alexander G. Ponomarenko (PIN), Alexander P. Rasnitsyn (PIN), Irina D. Sukatsheva (PIN), and Dmitry E. Shcherbakov (PIN). Particular assistance in preparation of the manuscript of this paper was obtained from Andrè Nel (NNHN) and Edmund A. Jarzembowski (Nanjing Institute of Geology and Palaeontology and Center for Excellence in Life and Paleoenvironment, Chinese Academy of Sciences, China and Natural History Museum, London, United Kingdom). Dany Azar (Lebanese University, Fanar, Lebanon) and Andranik R. Manukyan (Kaliningrad Amber Museum, Kaliningrad, Russia) made a lot to prepare many amber inclusions of beetles for study. The author greatly appreciate Albert Allen (9235 Wenatchee Ct., Boise, Idaho, USA) for proposal to study many interesting specimens and his generous donation of the holotypes of Omma janetae sp. nov. and Polyakius alberti sp. nov. to the collection of ZIN. The rather great help was obtained from many colleagues of ZIN, including in studies of fossil specimens with usage of the fluorescence microscopy (Boris B. Anokhin), preparation pictures of specimens in the usual optics (Alexey V. Kovalev), Sergey Yu. Sinev and Boris A. Korotyaev in various advice. Besides, Alexander A. Prokin (Papanin Institute for Biology of Inland Waters of Russian Academy of Sciences, Borok, Yaroslavl Oblast, Russia) and Huali Chang (CNU) helped in picturing specimens in PIN and CNU. The authors greatly appreciate to all other colleagues provided him with specimens for study in addition to the above-mentioned ones and, in first turn, to Anders Damgaard (Copenhagen, Denmark), Carsten Gröhn (GPIH), Herbert Lutz (LNNR), Jakub Prokop (PrFUK), Dong Ren (CNU), Sonja Wedmann (SFNFM) and Wolfgang Weitschat (GPIH). The author thanks to Miguel A. Alonso-Zarazaga (Museo Nacional de Ciencias Naturales, Madrid, Spain) for his friendly advice in nomenclatural problems and John F. Lawrence (Australian National Insect Collection, Canberra, Australia) for some information on structures of modern ommatines. Zeng Xiantai (Zhengzhou, Henan, China) helped to provide amber inclusions for the collection of ZIN. The author appreciates very useful comments and suggestions by two anonymous reviewers. 
Conflicts of Interest: The author declares no conflict of interest.

\section{Appendix A}

After preparation of this manuscript the descriptions of three species appeared and all of them belong to a new genus not included in this review. An appendix is therefore necessary. Also, one Tetraphalerus species, the description which was published in 2017, was missed by the author and is added to this review. E.A. Jarzembowski kindly provided detailed discussion on the manuscript and great assistance in improving the text contributing very significant ideas and facts, including some data on the following two genera (Echinocups Kirejtshuk et Jarzembowski, gen. nov. and Bukhkalius Kirejtshuk et Jarzembowski, gen. nov.). Therefore, the co-authorship of E.A. Jarzembowski is appropriate.

Family Cupedidae Laporte, 1836

Subfamily Ommatinae Sharp et Muir, 1912

Genus Echinocups Kirejtshuk et Jarzembowski, gen. nov.

urn:lsid:zoobank.org:act:F64B94C4-6FBE-402F-ADBB-8383F04FB02F

Type species Notocupes neli Tihelka, Huang et Cai, 2020 [183], fossil, Lower/Upper Cretaceous, Upper Albian/Lower Cenomanian; Myanmar: Kachin (Burmese amber).

Composition. Echinocups neli comb. nov., and also Echinocups ohmkuhnlei (Jarzembowski, Wang et Zheng, 2020) [184], comb. nov. [Notocupes] and Echinocups denticollis (Jiang, Li, Song, Shi, Liu, Chen et Kong, 2020) [185], comb. nov. [Notocupes].

Diagnosis. Body elongate oval; head more or less transverse, subtriangular and weakly narrowed at base (neck), eyes medium-size to large and located at base, temples very short and retracted into prothoracic segment; prothorax subflattened, with widely explanate and carinate sides, its lateral edges strongly dentate, procoxae subcontiguous; dorsal integument with diffuse, dense and comparatively coarse microtubercles; elytra with $\mathrm{CuA}$ and $\mathrm{M}$ fused and curved towards $1 \mathrm{~A}$ subapically, cells large and arranged in longitudinal rows, longitudinal interspaces between these rows of cells bearing rather high tubercles (sharp spines), explanate stripe at least with one row of large cells or with additional rows of smaller cells and lateral edge densely dentate; abdominal ventrites 1-3 overlapping and others co-planar (abutting).

Notes. All three members of Echinocups gen. nov. were described as congeners of Notocupes because of some general body similarity. Nevertheless these three species are very different from all Notocupes sensu lato in the characteristics mentioned in the comparison bellow. Although the drawing of Echinocups denticollis comb. nov. shows the venation as should be the case in true congeners of Notocupes, it is here treated as erroneous, as all other characteristics of this species completely correspond with those in other species of Echinocups gen. nov.

The important feature of Echinocups gen. nov. is a discovery of the exposed aedeagus from the genital capsule in the holotype of Echinocups denticollis comb. nov. (Jiang et al., 2020: Figure 4) which is very reminiscent of that in Priacma and Gracilicupes [33] in the subfamily Cupedinae (but not Ommatinae). Other fossil cupedids showing exposed aedeagus fit with the traditional classification of the family Cupedidae [26,33], etc. Nevertheless, the attribution of Echinocups denticollis comb. nov. to the ommatines at the moment is based on the subcontiguous procoxal cavities.

Another feature of this new genus is its overlapping abdominal ventrites 1-3. The type of junction of abdominal ventrites is usually one of the group feature characterizing closely related species and very frequently used as diagnostic for supraspecific taxa. In contrast to the congeners of the new genus, the cupedine Priacma and Gracilicupes have co-planar ventrites. 
Comparison. This new genus is characterized by the general body outline somewhat similar to that in many representatives of Notocupes, but, unlike the latter, the three species considered as congeners of Echinocups gen. nov. have strongly dentate lateral edges of the prothorax, sharp spines on elytra, different elytral venation and overlapping abdominal ventrites. The co-planar abdominal ventrites are characteristic of most ommatines, including relatives of Notocupes (Notocupedini sensu Ponomarenko, 1969), although not infrequently the posterior edge of the abdominal ventrites in different ommatines somewhat elevated over the base of the following ventrites. The true overlapping (tegular) junction of abdominal ventrites is more characteristic of cupedines than ommatines, but the cupedine representatives with the Priacma-type aedeagus (Priacma and Gracilicupes), as mentioned above, have the co-planar abdominal ventrites. Thus, assignement of Echinocups gen. nov. to ommatines can be regarded as preliminary and could be revised after obtaining more data.

Etymology. The name of this new genus is formed from the Greek "Echinus" (spiny animal) and stem of the generic name "Cupes". Gender masculine.

Genus Bukhkalius Kirejtshuk et Jarzembowski, gen. nov. urn:lsid:zoobank.org:act:6012C376-EBAA-4255-83AC-D1193306BDAB

Type species Tetraphalerus lindae Jarzembowski, Wang et Zheng, 2019 [186]; fossil, Lower/Upper Cretaceous, Upper Albian/Lower Cenomanian; Myanmar: Kachin (Burmese amber).

Composition. Only type species (Bukhkalius lindae comb. nov.)

Diagnosis. Body elongate; head somewhat elongate, subtriangular and strongly narrowed at base (neck) and anteriorly, eyes large and located at base, temples very short; prothorax subglobular with neck-like anterior projection and incarinate, procoxae subcontiguous; dorsal integument with diffuse, dense and comparatively coarse microtubercles; elytra with indistinct and not fused veins, cells somewhat elongate and arranged in irregular longitudinal rows, explanate lateral stripe apparently with two rows of cells and lateral edge densely dentate; abdominal ventrites co-planar (abutting).

Comparison. This new genus is characterized by the general body outlines somewhat similar to that in many representatives of Tetraphalerus and Allophalerus gen. nov., but Bukhkalius gen. nov. has the head rather narrowing anteriorly, narrow neck and very large eyes, prothorax with narrow "neck", and densely serrate elytra sides. Besides, this new genus differs from the genera with subglobous prothorax (Cionocoleus, Cionocups gen. nov., Omma, Polyakius gen. nov. and Rhopalomma) in the clear "neck" of the head, and also from Cionocoleus and Cionocups gen. nov. also in the longitudinal rows of cells on elytra.

Etymology. The name of this new genus is dedicated to entomologist Sergey Petrovich Bukhkalo, who graduated from the Kharkov State University together with the author of this paper and who passed away in the summer of 2019. Gender masculine.

\section{References}

1. Handlirsch, A. Die Fossilen Insekten und die Phylogenie der Rezenten Formen: Ein Handbuch für Paläontologen und Zoologen; Wilhelm Engelmann: Leipzig, Germany, 1908; pp. 1-640, XXXVI Tafs.

2. Rohdendorf, B.B. Superorder Coleopteroidea. Paleozoiskie nasekomye Kuznetskogo basseina. Trudy Paleontol. Inst. Akademii Nauk SSSR 1961, 85, 393-469. (In Russian)

3. Carpenter, F.M. Superclass Hexapoda. In Treatise on Invertebrate Paleontology, Arthropoda; Part R; Moore, R.C., Kaesler, R.L., Eds.; The Geological Society of America and the University of Kansas: Boulder, CO, USA; Lawrence, MA, USA, 1992; Volume 4, pp. 1-655.

4. Rohdendorf, B.B. (Ed.) Mesozoic Beetles. Trudy Paleontol. Inst. Akad. Nauk SSSR 1977, 161, 1-204. (In Russian)

5. Larsson, S.G. Baltic Amber-A Palaeobiological Study. Entomonographic 1978, 1, 1-192.

6. Spahr, U. Systematischer Katalog der Bernstein- und Kopal-Käfer (Coleoptera). Stuttgarter Beitr. Naturkunde $1981,80,1-107$. 
7. Hieke, F.; Pietrzeniuk, E. Die Bernstein-Käfer des Museums für Naturkunde, Berlin (Insecta, Coleoptera). Mitt. Zool. Mus. Berlin 1984, 60, 297-326.

8. Rasnitsyn, A.P. (Ed.) Jurassic insects of Siberia and Mongolia. Trudy Paleontol. Inst. Akademii Nauk SSSR 1985, 211, 1-191, XXIV pls. (In Russian)

9. Rasnitsyn, A.P. (Ed.) Late Mesozoic insects of Eastern Transbaikalia. Trudy Paleontol. Inst. Akademii Nauk SSSR 1990, 239, 1-223, Pl. XVI. (In Russian)

10. Kirejtshuk, A.G.; Merkl, O.; Kernegger, F. A new species of the genus Pentaphyllus Dejean, 1821 (Coleoptera, Tenebrionidae, Diaperinae) from the Baltic amber and checklist of the fossil Tenebrionidae. Zoosystematica Rossica 2008, 17, 131-137.

11. Kirejtshuk, A.G.; Ponomarenko, A.G.; Prokin, A.A.; Chang, H.; Nikolajev, G.V.; Ren, D. Current knowledge on Mesozoic Coleoptera from Daohugou and Liaoning (North East China). Acta Geol. Sin. 2010, 84, 783-792. [CrossRef]

12. Gratshev, V.G.; Legalov, A.A. New Mesozoic Ithyceridae beetles (Coleoptera). Paleontol. J. 2011, 45, 76-81. [CrossRef]

13. Legalov, A.A. Fossil Mesozoic and Cenozoic weevils (Coleoptera, Obrienioidea, Curculionoidea. Paleontol. J. 2015, 49, 1442-1513. [CrossRef]

14. Legalov, A.A. A review of the Curculionoidea (Coleoptera) from European Eocene ambers. Geosciences 2020, 10, 16. [CrossRef]

15. Yunakov, N.N.; Kirejtshuk, A.G. Notes on the fossil broad-nosed weevils with description of a new genus and species of the tribe Naupactini from Baltic amber (Coleoptera: Curculionidae: Entiminae). ZooKeys 2011, 160, 73-96. [CrossRef] [PubMed]

16. Aristov, D.S.; Bashkuev, A.S.; Golubev, V.K.; Gorochov, A.V.; Karasev, E.V.; Kopylov, D.S.; Ponomarenko, A.G.; Rasnitsyn, A.p.; Rasnitsyn, D.A.; Sinitshenkova, N.D.; et al. Fossil Insects of the Middle and Upper Permian of European Russia. Paleontol. J. 2013, 47, 641-832. [CrossRef]

17. Alekseev, V.I. The beetles (Insecta: Coleoptera) of Baltic amber: The checklist of described species and preliminary analysis of biodiversity. Zool. Ecol. 2013, 23, 5-12. [CrossRef]

18. Kirejtshuk, A.G.; Azar, D. Current knowledge of Coleoptera (Insecta) from the Lower Cretaceous Lebanese amber and taxonomical notes for some Mesozoic groups. Terr. Arthropod Rev. 2013, 6, 103-134. [CrossRef]

19. Kirejtshuk, A.G.; Nel, A. Current knowledge of Coleoptera (Insecta) from the Lowermost Eocene Oise amber. Insect Syst. Evol. 2013, 44, 175-201. [CrossRef]

20. Ponomarenko, A.G.; Aristov, D.S.; Bashkuev, A.S.; Gubin, Y.M.; Khramov, A.V.; Lukashevich, E.D.; Popov, Y.A.; Pritykina, L.N.; Sinitsa, S.M.; Sinitshenkova, N.D.; et al. Upper Jurassic Lagerstätte Shar Teg, Southwestern Mongolia. Paleontol. J. 2014, 48, 1573-1682. [CrossRef]

21. Fanti, F. World catalog of fossil Cantharidae. Foss. Miner. Rev. 2017, 2, 1-52.

22. Telnov, D.; Bukejs, A. Catalogue and composition of fossil Anthicidae and Ischaliidae (Insecta: Coleoptera). Palaeontol. Electr. 2019, 22, 1-27. [CrossRef]

23. Nabozhenko, M.V. The Fossil Record of Darkling Beetles (Insecta: 2 Coleoptera: Tenebrionidae). Geosciences 2019, 9, 514. [CrossRef]

24. McKenna, D.D.; Wild, A.L.; Kanda, K.; Bellamy, C.L.; Beutel, R.G.; Caterino, M.S.; Farnum, C.W.; Hawks, D.C.; Ivie, M.A.; Jameson, M.L.; et al. The beetle tree of life reveals that Coleoptera survived end-Permian mass extinction to diversify during the Cretaceous terrestrial revolution. Syst. Entomol. 2015, 40, 835-880. [CrossRef]

25. Toussaint, E.A.; Seidel, M.; Arriga-Varela, E.; Hájek, J.; Král, D.; Sekerka, L.; Short, A.Z.; Fikaček, M. The peril of dating beetles. Syst. Entomol. 2017, 42, 1-10. [CrossRef]

26. Ponomarenko, A.G. Istoricheskoe Razvitie Zhestkokrylykh-Arkhostemat [Historical Development of the Archostomatan Beetles]. Trudy Paleontol. Inst. Akademii Nauk SSSR 1969, 125, 1-240. (In Russian)

27. Ponomarenko, A.G. 2.2.1.3.2. Superorder Scarabaeidea Laicharting, 1781. Order Coleoptera Linné, 1758. The beetles. In History of Insects; Rasnitsyn, A.P., Quicke, D.L.J., Eds.; Kluwer Academic Publishers: Dordrecht, The Netherlands, 2002; pp. 1-517.

28. Kirejtshuk, A.G. Evolution of mode of life as the basis for division of the beetles into groups of high taxonomic rank. In Advances in Coleopterology; Zunino, M., Belles, X., Blas, M., Eds.; AEC: Barcelona, Spain, 1991; pp. 1-323. 
29. Ponomarenko, A.G.; Kirejtshuk, A.G. Systematic List of Fossil Beetles of Cupedina, Carabina and Scarabaeina (Part 1). Available online: https://www.zin.ru/animalia/coleoptera/rus/paleos_0.htm (accessed on 20 August 2009). (In Russian)

30. Kirejtshuk, A.G.; Ponomarenko, A.G. Systematic List of Fossil Beetles of Cupedina, Carabina and Scarabaeina (Part 1). Available online: https://www.zin.ru/animalia/coleoptera/rus/paleosy0.htm (accessed on 20 May 2019). (In Russian)

31. Bouchard, P.; Bousquet, Y.; Davies, A.E.; Alonso-Zarazaga, M.A.; Lawrence, J.F.; Lyal, C.H.C.; Newton, A.F.; Reid, C.A.M.; Schmitt, M.; Ślipiński, S.A.; et al. Family-group names in Coleoptera (Insecta). ZooKeys 2011, 88, 1-972. [CrossRef]

32. Kirejtshuk, A.G.; Poschmann, M.; Prokop, J.; Garrouste, R.; Nel, A. Evolution of the elytral venation and structural adaptations in the oldest Palaeozoic beetles (Insecta: Coleoptera: Tshekardocoleidae). J. Syst. Palaeontol. 2014, 12, 575-600. [CrossRef]

33. Kirejtshuk, A.G.; Nel, A.; Kirejtshuk, P.A. Taxonomy of the reticulate beetles of the subfamily Cupedinae (Coleoptera: Archostemata), with a review of the historical development. Invertebr. Zool. 2016, 13, 61-190. [CrossRef]

34. Crowson, R.A. The evolutionary history of Coleoptera as documented by fossil and comparative evidence. Atti X Congresso Nazionale Italiano di Entomologia, Sassari 1975, 1974, 47-90.

35. Meyen, S.V. Osnovy Paleobotaniki (Fundamentals of Paleobotany); Nedra: Moscow, Russia, 1987; pp. 1-403. (In Russian)

36. Pearse, A.S. Zoological names. A List of Phyla, Classes, and Orders; Duke University Press: Durham, NC, USA, 1936; pp. 1-24.

37. Handlirsch, A. Zur Phylogenie der Hexapoden. Sitzungsberichte der Kaiserlichen Akademie der Wissenschaften in Wien 1903, 112, 716-738.

38. Hedges, S.B.; Kumar, S. (Eds.) The Timetree of Life; Foreword by Watson, J.D.; Oxford University Press: New York, NY, USA, 2009; pp. 1-551.

39. Boudreaux, H.B. Arthropod Phylogeny, with Special Reference to Insects; Willey \& Sons: New York, NY, USA, 1979; pp. 1-320.

40. Kukalová-Peck, J. Chapter 6: Fossil history and the evolution of hexapod structures. In The insects of Australia, a Textbook for Students and Research Workers, 2nd ed.; Naumann, I.D., Ed.; Melbourne University Press: Melbourne, Australia, 1991; pp. 1-542.

41. Kirejtshuk, A.G.; Nel, A. Skleroptera, a new order of holometabolous insects (Insecta) from the Carboniferous. Zoosystematica Ross. 2013, 22, 247-257.

42. Kirejtshuk, A.G.; Nel, A. Is Skleroptera (Stephanastus) an order in the stemgroup of Coleopterida (Insecta)? Insect Syst. Evol. 2019, 50, 670-678, online publication date 21 December 2018. [CrossRef]

43. Chen, S.; T'an, C.-C. A new family of Coleoptera from the Lower Cretaceous of Kansu. Acta Entomol. Sin. 1973, 16, 169-178.

44. Zhang, H.-C. Early Cretaceous insects from the Dalazi Formation of the Zhixin basin, Jilin Province, China. Palaeoworld 1997, 7, 75-103.

45. Kukalová, J. On the systematic position of the supposed Permian beetles, Tschekardocoleidae, with a description of a new collection from Moravia. Sbornik Geol. Ved, Paleontol. 1969, 11, 139-161.

46. Linnæus, C. Systema Naturæ per Regna Tria Naturæ, Secundum Classes, Ordines, Genera, species, Cum Characteribus, Differentiis, Synonymis, Locis, 10th ed.; Tomus, I., Ed.; Salvius: Stockholm, Sweden, 1758; pp. 1-824.

47. Burmeister, H. Handbuch der Entomologie. Bd. 2. Besondere Entomologie. Abt.1. Schnabelkerfe. Rhynchota; Reimer: Berlin, Germany, 1835; pp. 1-400.

48. Machatschke, J.W. Bemerkungen zum System der Coleoptera. Ber. 9. Wanderversammlung Deutscher Entomologen 6-8 Juni 1962. Tagungsber 1962, 45, 121-137.

49. Crowson, R.A. The Natural Classification of the Families of Coleoptera; EW. Classey Ltd.: Middlesex, UK, 1967; pp. 1-214.

50. Lawrence, J.F.; Ślipiński, A.; Ainsley, E.; Seago, A.; Thayer, M.K.; Newton, A.F.; Marvaldi, A.E. Phylogeny of the Coleoptera based on morphological characters of adults and larvae. Ann. Zool. 2011, 61, 1-217. [CrossRef]

51. Lameere, A. Nouvelles notes pour la classification de Coleoptera. Ann. Soc. Entomol. Belg. 1903, 47, $155-165$. 
52. Yan, E.V.; Beutel, R.G.; Lawrence, J.F.; Yavorskaya, M.I.; Hörnschemeyer, T.; Pohl, H.; Vassilenko, D.V.; Bashkuev, A.S.; Ponomarenko, A.G. Archaeomalthus (Coleoptera, Archostemata) a 'ghost adult' of Micromalthidae from Upper Permian deposits of Siberia? Hist. Biol. 2019, 1-9. [CrossRef]

53. Kukalová, J. Permian Protelytroptera, Coleoptera and Protorthoptera (Insecta) of Moravia. Sbornik Geologických věd: Paleontologie 1965, 6, 61-95.

54. Nel, A.; Prokop, J.; Grandcolas, P.; Desutter-Grandcolas, L.; Garrouste, R.; Lapeyrie, J.; Anisyutkin, L.N.; Kirejtshuk, A.G. The beetle-like Palaeozoic and Mesozoic roachoids of the so-called "umenocoleoid" lineage (Dictyoptera: Ponopterixidae fam. nov.). Comptes Rendus Palevol 2014, 13, 545-554. [CrossRef]

55. Pace, R. An exceptional endogeous beetle: Crowsoniella relicta n. gen. n. sp. of Archostemata Tetraphaleridae from central Italy (XVI. Contribution to knowledge of endogeous beetles). Boll. Mus. Civico Storia Nat. Verona Botanica Zool. 1976, 2, 445-458.

56. Crowson, R.A. The systematic position and implications of Crowsoniella. Boll. Mus. Civico Storia Nat. Verona Botanica Zool. 1976, 2, 456-463.

57. Kirejtshuk, A.G.; Nel, A.; Collomb, F.-M. New Archostemata (Insecta: Coleoptera) from the French Paleocene and Early Eocene, with a note on the composition of the suborder. Ann. Soc. Entomol. Fr. 2010, 46, $216-217$. [CrossRef]

58. Kirejtshuk, A.G. Sikhotealinia zhiltzovae (Lafer, 1996)-Recent representative of the Jurassic coleopterous fauna (Coleoptera, Archostemata, Jurodidae). Proc. Zool. Inst. Russ. Acad. Sci. 1999, 281, 21-26.

59. Lafer, G.S. Family Sikhotealiniidae. In Key to the Insects of the Russian Far East; Ler, P.A., Ed.; Dal'nauka: Vladivostok, Russia, 1996; Volume III, Part 3; pp. 1-550.

60. Fedorenko, D.N. Evolution of the Beetle Hind Wing, with Special Reference to Folding (Insecta, Coleoptera); Pensoft Publishers: Sofia, Bulgaria; Moscow, Russia, 2009; pp. 1-335.

61. Yan, E.V.; Wang, B.; Ponomarenko, A.G.; Zhang, H. The most mysterious beetles: Jurassic Jurodidae (Insecta: Coleoptera) from China. Gondwana Res. 2014, 25, 214-225. [CrossRef]

62. Kirejtshuk, A.G.; Nel, A. Origin of the Coleoptera and significance of the fossil record. Eurasian Entomol. J. 2016, 15, 66-73. (In Russian)

63. Rohdendorf, B.B. A new family of Coleoptera from the Permian of the Urals. In Doklady Akademii Nauk, SSSR 1944, 44, 252-253.

64. Zalessky, G.M. On two Permian beetles. Doklady Akademii Nauk SSSR 1947, 56, 857-860. (In Russian)

65. Kukalová-Peck, J.; Beutel, R.G. Is the Carboniferous +Adiphlebia lacoana really the "oldest beetle"? Critical reassessment and description of a new Permian beetle family. Eur. J. Entomol. 2012, 109, 633-645. [CrossRef]

66. Lubkin, S.H.; Engel, M.S. Permocoleus, new genus, the first Permian beetle (Coleoptera) from North America. Ann. Entomol. Soc. Am. 2005, 98, 73-76. [CrossRef]

67. Pinto, I.D. Permian insects from Parana basin, South Brazil. 4. Coleoptera. Pesquisas (Zoologia) 1987, 19, 5-12.

68. Beckemeyer, R.J.; Engel, M.S. A second specimen of Permocoleus (Coleoptera) from the Lower Permian Wellington Formation of Noble County, Oklahoma. J. Kansas Entomol. Soc. 2008, 81, 4-7. [CrossRef]

69. Ponomarenko, A.G. Palaeozoic beetles of Cupididea of the European Part of the USSR. Paleontol. Zhurnal. 1963, 1, 70-85.

70. Hörnschemeyer, T. Fossil insects from the Lower Permian of Niedermoschel (Germany). The AMBA Projects AM/PFICM98/1.99. In Proceedings of the First International Palaeoentomology Conference, Moscow, Russia, 30 August-4 September 1999; pp. 57-59.

71. Hong, Y.C. Mesozoic Fossil Insects of Jiuquan Basin in Gansu Province; Geological Publishing House: Beijing, China, 1982; pp. 1-187. (In Chinese)

72. Martynov, A.V. New Permian Insects from Tikhie Gory. II. Neoptera (excluding Miomoptera). Trudy Geol. Muz. Akademii Nauk SSSR 1931, 8, 149-212. (In Russian)

73. Ponomarenko, A.G. Beetles of the family Cupedidae from the Lower Cretaceous locality of Semen, Transbaikalia. Paleontol. J. 2000, 34 (Suppl. 3), S317-S322.

74. Aristov, D.S.; Rasnitsyn, A.P. New insects from the Kungurian of Tshekarda fossil site in Permian territory of Russia. Russ. Entomol. J. 2015, 24, 17-35. [CrossRef]

75. Prokin, A.A.; Kirejtshuk, A.G.; Ponomarenko, A.G. On some Permian and Triassic larvae of Holometabola: Beetles or not? In: Abstracts of the Immature Beetles Meeting 2015, October 1-2, Prague, Czech Republic. Acta Entomol. Mus. Nation. Pragae 2015, 55, 882-884. 
76. LeConte, J.L. Classification of the Coleoptera of North America; Part I. Smithsonian Miscellaneus Collections; Smithsonian Institution: Washington, DC, USA, 1862; pp. 1-214.

77. Ross, D.A.; Pothecary, D.D. Notes on adults, eggs, and first-instar larvae of Priacma serrata (Cupedidae). Canad. Entomol. 1970, 102, 346-348. [CrossRef]

78. Ponomarenko, A.G. Cretaceous Insects from Labrador 4 A new family of beetles (Coleoptera: Archostemata). Psyche 1969, 76, 306-310. [CrossRef]

79. Martynov, A.V. Permian fossil Insects from the Arkhangelsk district. Part II. Neuroptera, Megaloptera and Coleoptera, with the description of two new beetles from Tikhie Gory. Trudy Paleontol. Inst. Akademii Nauk SSSR 1932, 2, 63-96.

80. Geertsema, H.; van den Heever, J.A. A new beetle, Afrocupes firmae gen. et sp. nov. (Permocupedidae), from the late Palaeozoic Whitehill Formation of South Africa. S. Afr. J. Sci. 1996, 92, 497-499.

81. Ponomarenko, A.G.; Bashkuev, A.S. First Triassic record of the beetle family Permocupedidae (Insecta: Coleoptera): A peculiar example of a Lazarus taxon. Paleontol. Zhurnal 2018, 92, 587-591. [CrossRef]

82. Srivastava, A.K. Insect and insect activities in Permian Gondvana of India. Permophi, A Newsletter of the Subcomission on Permian Stratigraphy (Int. Union Geol. Sci. 1997, 30, 17.

83. Ponomarenko, A.G.; Yan, E.V.; Huang, D.Y. New beetles (Coleoptera) from the terminal Middle Permian of China. Paleontol. J. 2014, 48, 191-200. [CrossRef]

84. Shcherbakov, D.E.; Makarkin, V.N.; Aristov, D.S.; Vasilenko, D.V. Taxonomic names, in Permian insects from the Russky Island, South Primorye. Russ. Entomol. J. 2009, 18, 7-16.

85. Ponomarenko, A.G. 2.3. New beetles (Insecta, Coleoptera) from the latter half of the Permian of European Russia. Paleontol. J. 2013, 47, 705-735. [CrossRef]

86. Ponomarenko, A.G. Beetles (Insecta, Coleoptera) of the Late Permian and Early Triassic. Paleontol. J. 2004, 38 (Suppl. 2), S185-S196.

87. Ponomarenko, A.G.; Mostovski, M.B. New beetles (Insecta: Coleoptera) from the Late Permian of South Africa. Afr. Invertebr. 2005, 46, 253-260.

88. Dunstan, B. Mesozoic insects of Queensland. 1. Introduction and Coleoptera. Publ. Geol. Surv. Qld. 1923, 273, 1-74.

89. Tillyard, R.J. Descriptions of the fossil Insects; Mesozoic and Tertiary Insects of Queensland and New South Wales. Descriptions of the fossil Insects and stratigraphical features. Qld. Geol. Surv. 1916, 253, 11-70.

90. Carpenter, F.M. Substitute names for some extinct genera of fossil insects. Psyche 1986, 92, 575-582. [CrossRef]

91. Von Mojsisovics, E. Das Gebirge um Hallstatt. Eine geologisch-paläontologische Studie aus den Alpen. 1 Teil, Die Mollusken-Faunen der Zlambach- und Hallstätter-Schichten. Abh. Kaiserlich-königl. Geol. Reichsanstalt. 1875, 6, 83-174.

92. Westwood, J.O. Contributions to fossil entomology. Q. J. Geol. Soc. Lond. 1854, 10, 378-396. [CrossRef]

93. Ponomarenko, A.G. A New Beetle species of the Genus Taldycupes (Taldycupedidae, Coleoptera) from the Permian of the Tunguska River Basin. Paleontol. J. 2006, 40, 295-296. [CrossRef]

94. Rohdendorf, B.B.; Ponomarenko, A.G. Order Coleoptera, beetles. In Osnovy Paleontologii. Spravochnik Dlya Paleontologov i Geologov SSSR. Chlenistonogie, Trakheinye i Khelitzerovye; Rohdendorf, B.B., Ed.; Izd. Akademii Nauk: Moscow, Russia, 1962; pp. 1-560. (In Russian)

95. Lin, Q.-B. Two beetle fossils from the Sanqiutian formation (Upper Triassic), Liuyang County of Hunan province. Zhongguo Kexueyuan Nanjing Dizhi Gushenswu Yanjiusuo Congkan Bull. Nanjing Inst. Geol. Palaeontol. Acad. Sin. 1983, 6, 297-307, (In Chinese with English Summary).

96. Ponomarenko, A.G.; Yan, E.V.; Wang, B.; Zhang, H.C. Revision of some early Mesozoic beetles from China. Acta Palaeontol. Sin. 2012, 51, 475-490.

97. Fujiyama, I. Mesozoic insect faunas of east Asia, part I. Introduction and Upper Triassic faunas. Bull. Nat. Sci. Mus. Tokyo 1973, 16, 331-386.

98. Ren, D. Insecta. Faunae and Stratigraphy of Jurassic-Cretaceous in Beijing and the Adjacent Areas; Seismic Publishing House: Beijing, China, 1995; pp. 47-121. (In Chinese)

99. Fabricius, J.C. Systema Eleutheratorum, Secundum Ordines, Genera, species; 1. Bibliopolii Academici Novi: Kiliae, Ukraine, 1801; pp. i-xxiv, 1-506.

100. Newman, E. Supplementary note to the synonymy of Passandra. Ann. Nat. Hist. 1839, 3, 303-304. [CrossRef]

101. Jarzembowski, E.A.; Wang, B.; Zheng, D.R. A slender new archaic beetle in Burmese amber (Coleoptera: Archostemata). Alcheringa 2017, 42, 110-114. [CrossRef] 
102. Ponomarenko, A.G. Zhuki semeystva Cupedidae iz nizhnego Triasa sredney Azii. Paleontol. Zhurnal 1966, 4 , 47-68. (In Russian)

103. Ponomarenko, A.G. New beetles of the family Cupedidae from Jurassic deposits of Karatau. Paleontol. Zhurnal 1964, 2, 49-62. (In Russian)

104. Waterhouse, C.O. Two new genera of Coleoptera belonging to the Cupesidae and Prionidae. Ann. Mag. Nat. Hist. 1901, 7, 520-521. [CrossRef]

105. Ponomarenko, A.G. New beetles of the family Cupedidae from the Mesozoic of Mongolia. Ommatini, Mesocupedini, Priacmini. Paleontol. J. 1997, 31, 389-399.

106. Tan, J.J.; Ren, D.; Shih, C.K. New beetles (Insecta: Coleoptera: Archostemata) from the late Mesozoic of north China. Ann. Zool. 2007, 57, 231-247.

107. Ponomarenko, A.G. Jurassic Archostematan beetles from Karatau (Coleoptera, Archostemata). In Yurskie Nasekomye Karatau; Nauka: Moscow, Russia, 1968; pp. 1-251. (In Russian)

108. Ponomarenko, A.G. Archostemata and Adephaga. In Mezozoyskie Nasekomye i Ostrakody Azii; Trudy Paleontol. Inst. Akad. Nauk SSSR: Moskva, Russia, 1993; Volume 252, pp. 1-159. (In Russian)

109. Ponomarenko, A.G. New beetles of the family Cupedidae (Coleoptera) from Mesozoic deposits of Transbaicalia. Entomol. Obozrenie 1966, 45, 138-143. (In Russian)

110. Ponomarenko, A.G. On the types of Mesozoic archostematan beetles (Insecta, Coleoptera, Archostemata) in the Natural History Museum, London. Paleontol. J. 2006, 40, 90-99. [CrossRef]

111. Ponomarenko, A.G. New Mesozoic cupedid beetles from Mongolia: Brochocoleini and Notocupedini. Paleontol. J. 1994, 28, 102-115.

112. Whalley, P.E.S. The systematics and palaeogeography of the Lower Jurassic insects of Dorset, England. Bull. Brit. Mus. Nat. Hist. 1985, 39, 107-189.

113. Jarzembowski, E.A.; Yan, E.V.; Wang, B.; Zhang, H.C. Brochocolein beetles (Insecta: Coleoptera) from the Lower Cretaceous of northeast China and southern England. Cretac. Res. 2013, 44, 1-11. [CrossRef]

114. Ponomarenko, A.G. A new beetle species of the genus Brochocoleus (Coleoptera, Cupedidae) from the Turonian of Kazakhstan. Paleontol. J. 1999, 33, 272-273.

115. Tan, J.J.; Ren, D.; Shih, C.K. New ommatids of Ommatinae (Coleoptera: Archostemata: Ommatidae) from the Yixian Formation of Liaoning, China. Prog. Nat. Sci. 2007, 17, 803-811.

116. Soriano, C.; Delclòs, X. New cupedid beetles from the Lower Cretaceous of Spain and the palaeogeography of the family. Acta Palaeontol. Polonica 2006, 51, 185-200.

117. Liu, Z.H.; Tan, J.J.; Jarzembowski, E.A.; Wang, B.; Ren, D.; Pang, H. Brochocoleus zhiyuani, a new species of brochocolein beetle (Coleoptera: Ommatidae) from the Cretaceous amber of Myanmar. Ann. Zool. 2017, 67, 79-85. [CrossRef]

118. Jarzembowski, E.A.; Yan, E.V.; Wang, B.; Zhang, H. Ommatin beetles (Insecta: Coleoptera) from the Lower Cretaceous of northeast China and southern England. Terr. Arthropod Rev. 2013, 6, 135-161. [CrossRef]

119. Martynov, A.V. To the knowledge of fossil insects from Jurassic beds in Turkestan 5 . On some interesting Coleoptera. Ezhegodnik Russkogo Paleontol. Obshestva 1926, 5, 1-39, (In Russian and English).

120. Jarzembowski, E.A.; Wang, B.; Zheng, D.R. A new scaly archaic beetle (Coleoptera: Archostemata) from mid-Cretaceous Burmese amber. Cretac. Res. 2019, 99, 315-320. [CrossRef]

121. Tan, J.J.; Ren, D. Mesozoic Archostematan Fauna from China; Science Press: Beijing, China, 2009; pp. 1-347, (In Chinese and English summary).

122. Jarzembowski, E.A.; Wang, B.; Zheng, D.R. An amber double first: A new brochocolein beetle (Coleoptera: Archostemata) from northern Myanmar. Proc. Geol. Assoc. 2016, 127, 676-680. [CrossRef]

123. Zeuner, F.E. Fossil insects from the Lower Lias of Charmouth, Dorset. Bull. Brit. Mus. Nat. Hist., Geol. 1962, 7, 155-171.

124. Tan, J.J.; Wang, J.; Ren, D.; Yang, X.K. New fossil species of ommatids (Coleoptera: Archostemata) from the middle Mesozoic of China illuminating the phylogeny of Ommatidae. BMC Evol. Biol. 2012, 12, 1-19. [CrossRef]

125. Ren, D.; Tan, J.J.; Ge, S.Q. New fossil ommatid (Coleoptera: Archostemata: Ommatidae) from Jehol biota of western Liaoning, China. Prog. Nat. Sci. 2006, 16, 639-643.

126. Brodie, P.B. A History of the Fossil Insects in the Secondary Rocks of England Accompanied by a Particular Account of the Strata in Which They Occur, and of the Circumstances Connected with Their Preservation; J. van Voorst: London, UK, 1845; pp. 1-130. 
127. Deichmüller, J.V. Die Insecten aus dem Lithographischen Schiefer im Dresdener Museum. Mitt. Koenigl. Mineral.-Geol. Prehistor. Mus. Dresden 1886, 7, 1-84.

128. Oppenheim, P. Die Insectenwelt des lithographischen Scheifers in Bayern. Palaeontographica 1888, 35, $215-254$.

129. Ponomarenko, A.G. Systematic position of some beetles from the Solenhofen shales of Bavaria. Paleontol. J. $1971,5,62-75$.

130. Cai, C.Y.; Huang, D.Y. Omma daxishanense sp. nov., a fossil representative of an extant Australian endemic genus recorded from the Late Jurassic of China (Coleoptera: Ommatidae). Alcheringa 2017, 41, 277-283. [CrossRef]

131. Crowson, R.A. Observation on the beetle family Cupedidae, with description of two new fossil forms and a key to the recent genera. Ann. Mag. Nat. Hist. 1962,13, 147-157. [CrossRef]

132. Jarzembowski, E.A.; Wang, B.; Zheng, D.R. A new ommatin beetle (Insecta: Coleoptera) with unusual genitalia from mid-Cretaceous Burmese amber. Cretac. Res. 2016, 71, 113-117. [CrossRef]

133. Yamamoto, S. A new genus of Brochocoleini beetle in Upper Cretaceous Burmese amber (Coleoptera: Archostemata: Ommatidae). Cretac. Res. 2017, 76, 34-39. [CrossRef]

134. Jarzembowski, E.A.; Wang, B.; Zheng, D.R. A new serrated archaic beetle (Coleoptera: Archostemata) from mid-Cretaceous Burmese amber. Cretac. Res. 2018, 92, 26-30. [CrossRef]

135. Stein, P. Euryomma, eine neue Gattungen der Anthmyidengruppe. Entomologische Nachrichten 1899, $25,19-22$.

136. Ashman, L.G.; Oberprieler, R.G.; Ślipiński, A. Rhopalomma stefaniae gen. et sp. n., the first ommatid beetle from the Upper Jurassic in Australia (Coleoptera: Archostemata: Ommatidae). Zootaxa 2015, 3980, 136-142. [CrossRef]

137. Jarzembowski, E.A.; Wang, B. An unusual basal beetle from Myanmar (Coleoptera: Archostemata). Alcheringa 2016, 40, 297-302. [CrossRef]

138. Tihelka, E.; Huang, D.Y.; Cai, C.Y. New data on Ommatidae (Coleoptera) from mid-Cretaceous Burmese amber. Cretac. Res. 2020, 106, 104253. [CrossRef]

139. Ponomarenko, A.G. Beetles. Scarabaeida (=Coleoptera). In Insects in Early Cretaceous Ecosystems of West Mongolia; Joint Soviet-Mongolian Paleontological Expedition: Moscow, Russia, 1986; Volume 28, pp. 1-214.

140. Giebel, C.G. Die Insecten und Spinnen der Vorwelt mit steter Berücksichtigung der lebenden Insekten und Spinnen. Die Fauna der Vorwelt 1856, 2, 1-511.

141. Heer, O. Die Insektenfauna der Tertiargebilde von Oeningen und von Radoboj in Croatien. Erste Abtheilung: Käfer. Neue Denkschriften der Allgemeinen Schweizerischen Gesellschaft für die Gesammten Naturwissenschaften (Leipzig) 1847, 8, 1-230.

142. Lin, Q.B. The Jurassic fossil insects from western Liaoning. Acta Palaeontol. Sin. 1976, 15, 97-116. (In Chinese)

143. Hong, Y.C. Middle Jurassic Fossil Insects in North China; Geological Publishing House: Beijing, China, 1983; pp. 1-223. (In Chinese)

144. Lin, Q.B. Early Mesozoic fossil insects from South China. Palaeontol. Sinica Ser. B 1986, 170, 1-112. (In Chinese)

145. Hong, Y.C.; Wang, W.L. Fossil insects from the Laiyang Basin, Shandong Province. In Stratigraphy and Palaeontology of Laiyang Basin, Shandong Province; Geological Publishing House: Beijing, China, 1990; pp. 44-189. (In Chinese)

146. Tan, J.J.; Ren, D.; Liu, M. New ommatids from the Late Jurassic of western Liaoning, China (Coleoptera: Archostemata). Insect Sci. 2005, 12, 207-216. [CrossRef]

147. Ren, D.; Tan, J.J. Ovatocupes: A new cupedid genus (Coleoptera: Archostemata: Cupedidae) from the Jehol biota (Late Jurassic) of western Liaoning, China. Entomol. News 2006, 117, 223-232.

148. Hong, Y.C. Insecta, I: Middle Jurassic insects. In Paleontological Atlas of Jilin Province; Geological Publishing House: Beijing, China, 1992; pp. 410-417. (In Chinese)

149. Zhang, J.F. Some fossil insects from the Jurassic of northern Hebei, China. In The Paleontology and Stratigraphy of Shandong; Paleontol. Soc. of Shandong: Shandong, China, 1986; pp. 74-84. (In Chinese)

150. Jarzembowski, E.A.; Wang, B.; Zhang, H.C.; Fang, Y. Boring beetles are not necessarily dull: New notocupedins (Insecta: Coleoptera) from the Mesozoic of Eurasia and East Gondwana. Cretac. Res. 2015, 52, 431-439. [CrossRef]

151. Ponomarenko, A.G. Coleoptera. P. 1658-1671. In: Upper Jurassic Lagerstätte Shar Teg, southwestern Mongolia. Paleontol. J. 2014, 48, 1573-1682. [CrossRef]

152. Hong, Y.C. The study of Early Cretaceous insects of Kezuo, west Liaoning. Prof. Pap. Stratigr. Palaeontol. 1987, 18, 76-87. (In Chinese) 
153. Strelnikova, O.D. New cupedids (Insecta: Coleoptera, Cupedidae) from the Lower Cretaceous of Buryatia. Paleontol. J. 2019, 53, 292-299. [CrossRef]

154. Wang, W.L.; Liu, M.W. A new species of Notocupes from the Cretaceous of Laiyang Basin, Shandong Province. Mem. Beijing Nat. Hist. Mus. 1996, 55, 79-82.

155. Tan, J.J.; Ren, D.; Shih, C.K.; Ge, S. New fossil beetles of the family Ommatidae (Coleoptera: Archostemata) from the Jehol Biota of China. Acta Geol. Sin. 2006, 80, 474-485.

156. Ponomarenko, A.G. Beetles from Jurassic of Siberia and Western Mongolia. p. 47-87. In Yurskie Nasekomye Sibiri i Mongolii; Trudy Paleontol. Inst. Akademii Nauk SSSR: Moscow, Russia, 1985; Volume 211, pp. 1-193+ XXIV pls.

157. Ponomarenko, A.G.; Ren, D. First Record of Notocupes (Coleoptera: Cupedidae) In Locality Daohugou, Middle Jurassic of Inner Mongolia, China. Ann. Zool. 2010, 60, 169-171. [CrossRef]

158. Hong, Y.C. Insecta. In Palaeontological Atlas of North China, II, Mesozoic Volume; Geological Publishing House: Beijing, China, 1984; pp. 128-185. (In Chinese)

159. Riek, E.F. On the occurrence of fossil insects in the Mesozoic rocks of Western Australia. Rec. Aust. Mus. 1968, 27, 311-312. [CrossRef]

160. Martin, S.K. Early Jurassic coleopterans from the Mintaja insect locality, Western Australia. Acta Geol. Sin. 2010, 84, 925-953. [CrossRef]

161. Lin, Q.B. Fossil insects from the Mesozoic of Zhejiang and Anhui provinces. In Division and Correlation of the Mesozoic Volcano-Sedimentary Strata in Zhejiang and Anhui Provinces; Nanjing Institute Geological Palaeontological Beijing Science Press: Beijing, China, 1980. (In Chinese)

162. Heller, K.M. Ein Neuer Cupedide. Entomol. Zeit. Wien 1913, 32, 234-237.

163. Ponomarenko, A.; Martínez-Delclòs, X. New beetles (Insecta: Coleoptera) from the Lower Cretaceous of Spain. Acta Geol. Hispanica 2000, 35, 47-52.

164. Jarzembowski, E.A.; Wang, B.; Zheng, D.R. The first cupedine beetle from Burmese amber (Coleoptera: Cupedidae). Comptes Rendus Palevol. 2017, 16, 241-247. [CrossRef]

165. Jarzembowski, E.A.; Wang, B.; Zheng, D.R. A new reticulated beetle (Coleoptera: Cupedidae) with aedeagus preserved from mid-Cretaceous amber of Myanmar. Cretac. Res. 2017, 80, 86-90. [CrossRef]

166. Tan, J.J.; Ren, D.; Shih, C.K. First record of fossil Priacma (Coleoptera: Archostemata: Cupedidae) from the Jehol Biota of western Liaoning, China. Zootaxa 2006, 1326, 55-68. [CrossRef]

167. Tan, J.J.; Ren, D. New fossil Priacmini (Insecta: Coleoptera: Archostemata: Cupedidae) from the Jehol Biota of China. J. Nat. Hist. 2006, 40, 2653-2661, (In Chinese with English Abstract). [CrossRef]

168. Motschulsky, V. Lettres de M. de Motschulsky à M. Ménétriés. Études Entomol. 1856, 5, 3-38.

169. Neboiss, A. Reclassification of Cupes Fabricius (sensu lato), with descriptions of new genera and species (Cupedidae, Coleoptera). Syst. Entomol. 1984, 9, 443-477. [CrossRef]

170. Chevrolat, A. Iconographie du Règne Animal de G. Cuvier: Ou, Représentation D'après Nature de L'une des Espèces Les Plus et Souvent non Encore Figurées de Chaque Genre D'animaux; Volume 1. Insectes; Guérin-Méneville, M.E.E., Baillière, J.B., Eds.; Baillière: Paris, France, 1829; pp. 1-576.

171. Lea, A.M. Descriptions of new species of Australian Coleoptera (Pt. vi). Proc. Linnean Soc. New South Wales 1902, 26, 481-513.

172. Tröster, G. Zwei neue mitteleuropäische Arten der Gattung Tenomerga Neboiss 1984 aus dem Mitteleozän der Grube Messel und des Eckfelder Maares (Coleoptera: Archostemata: Cupedidae). Mainzer Naturwissenschaftliches Archiv 1993, 31, 169-176.

173. Kirejtshuk, A.G. A revision of the genus Cupes Fabricius, 1801 from Baltic amber and some notes on taxonomy and composition of the family Cupedidae (Coleoptera, Archostemata). Mitt. Bayer. Staatssammlung Palaontol. Hist. Geol. 2005, 89, 55-84.

174. Hong, Y.C.; Wang, W.L. Miocene Emboptera and Coleoptera (Insecta) of Shanwang, Shandong Province, China. Prof. Pap. Stratigr. Palaeontol. 1987, 17, 257-262. (In Chinese)

175. Gersdorf, E. Dritter Beitrag über Käfer (Coleoptera) aus dem Jungtertiär von Willershausen, Bl. Northeim 4226. Geol. Jahrbuch Reihe 1976, 36, 103-145.

176. Iablokoff-Khnzorian, S.M. New beetles from Baltic amber. Paleontol. Zhurnal 1960, 1, 90-101. (In Russian)

177. De Peierimhoff, P. Le Cupes de l'ambre de la Baltique. Bull. soc. entomol. France 1909, 14, 57-60.

178. Ponomarenko, A.G. Erster Fund eines Cupediden im Neogen Europas (Coleoptera: Cupedidae). Vestnik Eskoslovenské Spolenosti Zoologicke 1973, 37, 101-103. 
179. Lubkin, S.H. Paracupes svitkoi (Coleoptera: Cupedidae), a new species from the Cretaceous of New Jersey. Acta Zool. Cracov. 2003, 46, 189-194.

180. Tan, J.J.; Ren, D.; Shih, C.K. New Cupedids from the Middle Jurassic of Inner Mongolia, China (Coleoptera: Archostemata). Ann. Zool. 2006, 56, 1-6.

181. Tan, J.J.; Huang, D.Y.; Ren, D. First record of fossil Mesocupes from China (Coleoptera: Archostemata: Cupedidae). Acta Geol. Sin. 2007, 81, 688-696. [CrossRef]

182. Li, Y.D.; Cai, C.Y. Early evolution of Cupedidae revealed by a mid-Cretaceous reticulated beetle from Myanmar (Coleoptera: Archostemata). Syst. Entomol. 2019, 44, 777-786. [CrossRef]

183. Tihelka, E.; Huang, D.; Cai, C. New notocupedin beetle in Cretaceous Burmese amber (Coleoptera: Archostemata: Ommatidae). Palaeoentomology 2019, 2, 570-575. [CrossRef]

184. Jarzembowski, E.A.; Wang, B.; Zheng, D. The first notocupedin beetle in mid-Cretaceous amber of northern Myanmar (Insecta: Coleoptera: Archostemata). Cretac. Res. 2020, 106, 104225. [CrossRef]

185. Jiang, Z.; Li, Y.; Song, C.; Shi, H.; Liu, Y.; Chen, R.; Kong, F. A new species of the genus Notocupes from mid-Cretaceous Burmese amber (Coleoptera: Archostemata: Ommatidae). Cretac. Res. 2020, 108, 104335. [CrossRef]

186. Jarzembowski, E.A.; Wang, B.; Zhang, H. Another amber first: A tiny tetraphalerin beetle (Coleoptera: Archostemata) in Myanmar birmite. Cretac. Res. 2017, 78, 84-88. [CrossRef]

(C) 2020 by the author. Licensee MDPI, Basel, Switzerland. This article is an open access article distributed under the terms and conditions of the Creative Commons Attribution (CC BY) license (http://creativecommons.org/licenses/by/4.0/). 